LBNL-53950

\title{
Life-Cycle Cost Analysis of Energy Efficiency Design Options for Residential Furnaces and Boilers
}

\author{
James Lutz, Alex Lekov, Camilla Dunham Whitehead, Peter Chan, \\ Steve Meyers, and James McMahon \\ Energy Analysis Department \\ Environmental Energy Technologies Division \\ Ernest Orlando Lawrence Berkeley National Laboratory \\ University of California \\ Berkeley, CA 94720
}

January 2004

This work was supported by the Office of Building Technologies and Community Systems of the U.S. Department of Energy, under Contract No. DE-AC03-76SF00098. 



\begin{abstract}
In 2001, the U.S. Department of Energy (DOE) initiated a rulemaking process to consider whether to amend the existing energy efficiency standards for furnaces and boilers. A key factor in DOE's consideration of new standards is the economic impacts on consumers of possible revisions to energy-efficiency standards. Determining cost-effectiveness requires an appropriate comparison of the additional first cost of energy efficiency design options with the savings in operating costs. DOE's preferred approach involves comparing the total life-cycle cost (LCC) of owning and operating a more efficient appliance with the LCC for a baseline design. This study describes the method used to conduct the LCC analysis and presents the estimated change in LCC associated with more energy-efficient equipment. The results indicate that efficiency improvement relative to the baseline design can reduce the LCC in each of the product classes considered.
\end{abstract}





\section{TABLE OF CONTENTS}

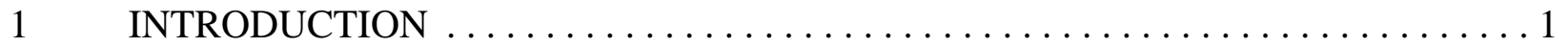

2 FURNACE AND BOILER TECHNOLOGY OVERVIEW $\ldots \ldots \ldots \ldots \ldots \ldots \ldots . \ldots 2$

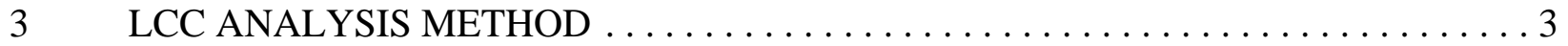

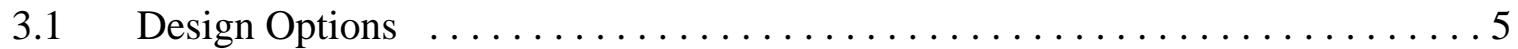

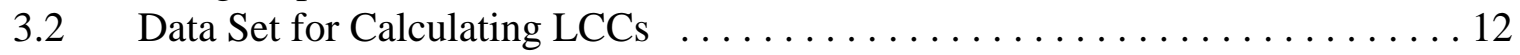

3.2.1 New Construction versus Replacement Installations . . . . . . . . 13

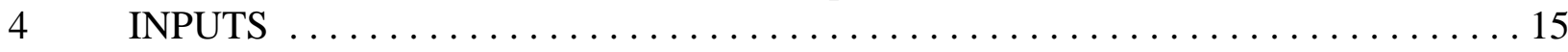

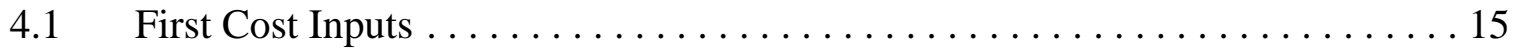

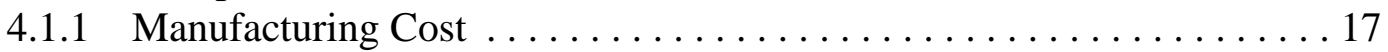

4.1.2 Installation Cost .............................. 19

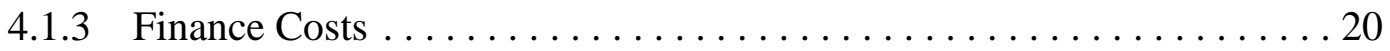

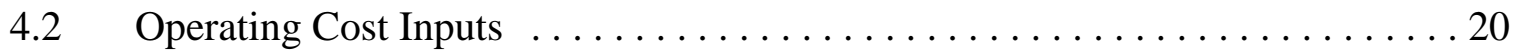

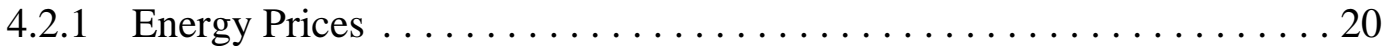

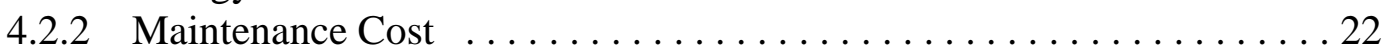

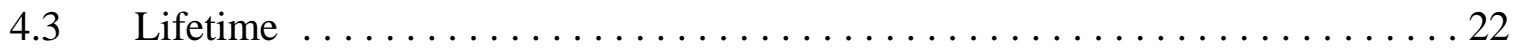

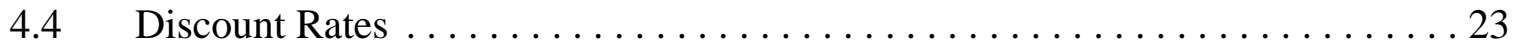

4.4.1 Approach for Estimating Discount Rates $\ldots \ldots \ldots \ldots \ldots \ldots \ldots . \ldots 23$

4.4.2 Discount Rate Applied to New Housing Equipment $\ldots \ldots \ldots \ldots \ldots 23$

4.4.3 Discount Rate Applied to Replacement Equipment ............. 23

4.4.4 Accounting for Variation in Discount Rates .................. 24

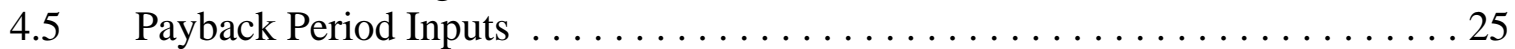

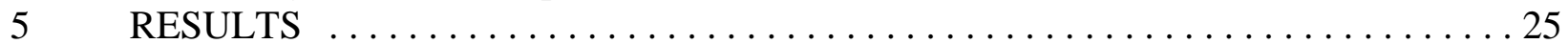

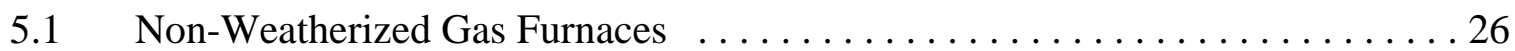

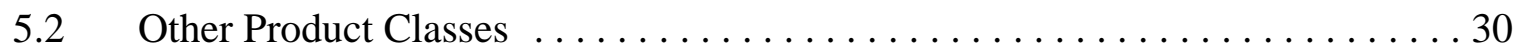

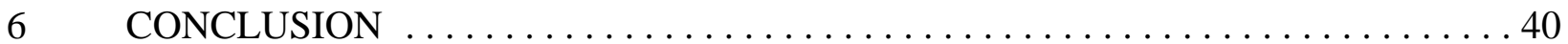

\section{LIST OF TABLES}

Table 1.1 Market Statistics for Furnaces and Boilers by Product Class . . . . . . . . . . . 2

Table 3.1 Criteria for Selection of RECS Household Data by Product Class $\ldots \ldots \ldots \ldots 13$

Table 3.2 New Construction Share for Residential Furnaces and Boilers . ........... 15

Table 4.1 Relevant Sizes of Generic Models for Non-Weatherized and Weatherized

Gas Furnaces . ................................ 18

Table 4.2 Relevant Sizes of Generic Models for Manufactured-Home Furnaces . . . . . . 18

Table 4.3 Relevant Sizes of Generic Models for Oil-Fired Furnaces . . . . . . . . . . . . 18

Table 4.4 Manufacturing Cost Scalars for Furnaces ....................... 19

Table 4.5 Furnace and Boiler Lifetimes Used in the LCC Analysis (years) $\ldots \ldots \ldots \ldots 22$

Table 4.6 After-Tax Real Interest or Return Rates for Household Debt and Equity Types . . 24

Table 5.1 LCC and PBP Results for Non-Weatherized Gas Furnaces $\ldots . \ldots \ldots \ldots \ldots 27$ 
Table 5.3 LCC and PBP Results for Manufactured-Home Gas Furnaces . . . . . . . . . 33

Table $5.4 \quad$ LCC and PBP Results for Oil-Fired Furnaces . . . . . . . . . . . . . . . . . . . . 35

Table 5.5 LCC and PBP Results for Hot-Water Gas Boilers . . . . . . . . . . . . . . . . . . 37

Table 5.6 LCC and PBP Results for Hot-Water Oil-fired Boilers . . . . . . . . . . . . . . . 39

\section{LIST OF FIGURES}

Figure 3.1 Non-Weatherized Gas Furnace LCC Analysis-Efficiency Levels and

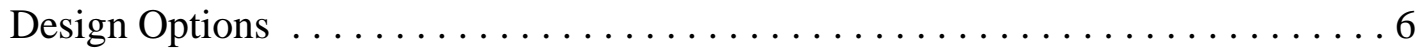

Figure 3.2 Weatherized Gas Furnace LCC Analysis-Efficiency Levels and Design Options . . 7

Figure 3.3 Manufactured Home Gas Furnace LCC Analysis-Efficiency Levels and

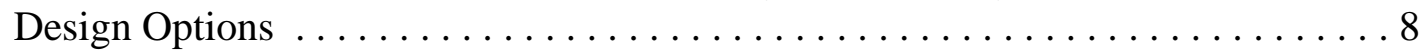

Figure 3.4 Oil-Fired Furnace LCC Analysis-Efficiency Levels and Design Options . . . . . . 9

Figure 3.5 Hot-Water Oil Boiler LCC Analysis-Efficiency Levels and Design Options . . . 10

Figure 3.6 Hot-Water Gas Boiler LCC Analysis-Efficiency Levels and Design Options . . . 11

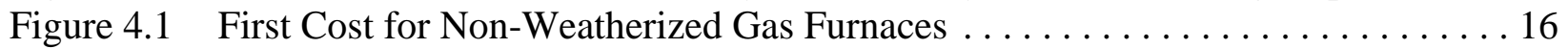

Figure 4.2 Manufacturing Costs (\$) for Baseline Non-Weatherized Furnaces by Input Capacity and Airflow Capacity . . . . . . . . . . . . . . . . . . . 17

Figure 5.1 Range of LCC Savings by Design Option for Non-Weatherized Gas Furnaces . . 29 Figure 5.2 LCC Savings for Each Census Division for the 90\% AFUE Condensing Furnace 30 Figure 5.3 Range of LCC Savings by Design Option for Weatherized Gas Furnaces . . . . . . 32 Figure 5.4 Range of LCC Savings by Design Option for Manufactured-Home Gas Furnaces 34 Figure 5.5 Range of LCC Savings by Design Option for Oil-Fired Furnaces . . . . . . . . . . 36 Figure 5.6 Range of LCC Savings by Design Option for Hot-Water Gas Boilers . . . . . . . . . 38 Figure 5.7 Range of LCC Savings by Design Option for Hot-Water Oil-Fired Boilers . . . . 40

\section{APPENDICES}

APPENDIX A: GLOSSARY OF VARIABLES AND THEIR VALUES FROM EIA'S RECS97 . . . . . . . . . . . . . . . . . . . . A-1

APPENDIX B: DISTRIBUTION OF DISCOUNT RATES . . . . . . . . . . . B-1 APPENDIX C: LCC AND PAYBACK PERIOD RESULTS USING ALTERNATIVE

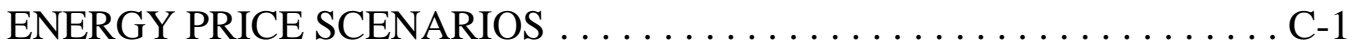

APPENDIX D: LCC AND PAYBACK PERIOD RESULTS USING ALTERNATIVE INSTALLATION COST SCENARIOS $\ldots \ldots \ldots \ldots \ldots \ldots \ldots \ldots \ldots$ D-1 


\section{INTRODUCTION}

The National Appliance Energy Conservation Act of 1987 (NAECA) requires the U.S. Department of Energy (DOE) to consider amendments to the energy conservation standards to increase efficiency in residential furnaces and boilers. This equipment represents a large opportunity for savings because it accounts for 25-30 percent of the total primary energy used in U.S. residential buildings, which was around 21 quads in 2001).

Regulations that took effect in 1992 set the initial Federal energy conservation standard in terms of the Annual Fuel Utilization Efficiency (AFUE) descriptor at a minimum value of $78 \%$ for most furnaces, at $75 \%$ for manufactured home furnaces, and at $75 \%$ for gas steam boilers and $80 \%$ for other boilers. In 2001, DOE initiated a rulemaking process to consider whether to amend the existing energy efficiency standards for furnaces and boilers. The rulemaking process used by DOE consists of a number of interrelated analytical steps. The authors are part of the group at LBNL that coordinated and conducted the technical analysis for DOE. ${ }^{1}$

A key factor in DOE's consideration of new standards is the economic impacts on consumers of possible revisions to U.S. residential furnace and boiler energy-efficiency standards. Determining cost-effectiveness requires an appropriate comparison of the additional first cost of energy efficiency design options with the savings in operating costs. DOE's preferred approach involves comparing the total life-cycle cost (LCC) of owning and operating a more efficient appliance with the LCC for a basecase design. The basecase represents the typical type of equipment that consumers would be likely to use in the absence of new standards.

The LCC calculated in this analysis expresses the costs of installing and operating a furnace or boiler for its lifetime starting in the year 2012 - the year a new standard would take effect.

The analysis also calculated the payback period (PBP) for energy-efficiency design options. The PBP represents the number of years of operation required to pay for the increased efficiency features. It is the change in purchase expense due to an increased efficiency standard divided by the change in annual operating cost that results from increased efficiency.

The main focus of the analysis was on design options for improving efficiency of fuel use, but we also evaluated options for improving efficiency of electricity use in furnace blowers and boiler pumps.

The analysis considered six product classes for furnaces and boilers. The level of unit shipments for each class in 2000 is shown in Table 1.1. Since non-weatherized gas furnaces comprise by far the largest class, DOE devoted the most attention to this product. 
Table 1.1 Market Statistics for Furnaces and Boilers by Product Class

\begin{tabular}{|l|c|c|}
\hline Product Class & Shipments in 2000 & Number of Models (2001) \\
\hline Non-weatherized gas furnaces & $\sim 2,645,000$ & 6907 \\
\hline Weatherized gas furnaces & $\sim 325,000$ & 4476 \\
\hline Non-weatherized oil-fired furnaces & 120,000 & 868 \\
\hline Manufactured home gas furnaces & $\sim 130,000$ & 70 \\
\hline Hot water gas boilers & $\sim 190,000$ & 990 \\
\hline Hot water oil-fired boilers & $\sim 100,000$ & 640 \\
\hline
\end{tabular}

Sources: Shipments based on data provided by Gas Appliance Manufacturers Association (GAMA)2; number of models is from GAMA directory ${ }^{3}$

\section{FURNACE AND BOILER TECHNOLOGY OVERVIEW}

Fuel-burning furnaces provide heat by drawing combustion products through a heat exchanger. Furnaces pass air over the outside of the heat exchanger, transferring the heat from the fuel to the air. Fuel-burning furnaces exhaust the products of combustion to the atmosphere through the flue passage connected to the heat exchanger. Furnaces use a fan to propel circulating air over the heat exchanger and air through the distribution system in the house.

Manufacturers rate non-weatherized furnaces as if they are isolated from the conditioned space where they are located. In this isolated combustion system (ICS) rating, furnaces draw combustion and dilution air from the outdoors. This differs from the "indoors" rating, which assumes that the furnace draws the combustion and dilution air from the conditioned space.

Weatherized furnaces are only used as part of a package unit, which means that the air conditioner is in the same box. They are installed outside (often as a rooftop unit) and are properly insulated. We do not know of any manufacturer that presently sells a stand-alone furnace approved for outdoor installation. The main difference between a weatherized furnace and a non-weatherized furnace is that the weatherized furnace has more insulation and an external case. Differences in jacket losses also affect test procedure results. The heat loss through the jacket in a weatherized furnace is totally dissipated outside, resulting in a lower efficiency compared to an equivalent non-weatherized furnace installed indoors.

Non-weatherized gas furnaces can be either non-condensing or condensing. Condensing gas furnaces recover so much heat from the combustion products that some of the water vapor condenses and turns into liquid. There are no condensing weatherized furnaces, because the condensate could freeze and damage the furnace. When the flue temperature is substantially higher than the dew point and the latent heat (the heat from condensation) is lost through the flue, the furnace is classified as non-condensing. 
If the furnace condenses the water (typically with the addition of a secondary corrosion-resistant heat exchanger) and drains it out, the flue temperature is much lower, and the AFUE is higher (over 90\%). A condensing furnace requires some additional equipment, such as an additional stainless steel heat exchanger and a condensate drain device. Condensing furnaces also require a different venting system, since the buoyancy of the flue gases is not sufficient to draw the gases up a regular chimney. Plastic through-the-wall venting systems are typically used in conjunction with condensing furnaces. Condensing furnaces present a higher equipment cost, but provide significant energy savings.

Manufactured home furnaces are a separate class of furnaces, due to three differences. They employ sealed combustion, pre-heat the combustion air drawn from outside, and have a very specific physical size constraints. These furnaces have historically had a lower efficiency standard and were considered as a separate product in rulemaking in the early 1990s.

Boilers are heating devices that transfer heat from the combustion gases to water, which then heats up the required space through a hydronic (hot-water) or steam system. The technology used for steam boilers is the same as for hot-water boilers, except that circulating pumps are not used in steam boilers. Boiler capacities range greatly, but they tend to be higher than for furnaces.

Boilers on the market are distinguished by the type of material: used for the heat exchanger, cast-iron sectional, steel fire-tube, copper water-tube, or aluminum. Cast-iron boilers are the most common and are typically gas-fired. Steel boilers are also fairly common, are perceived to be less expensive, and are always oil-fired. Copper boilers are less common. Aluminum boilers are relatively uncommon.

Hot-water boilers come in all material types. Steam boilers are either cast-iron sectional or steel fire-tube type.

\section{LCC ANALYSIS METHOD}

The goal of the LCC analysis is to calculate the LCC for alternative equipment designs in houses that are representative of U.S. households that buy furnaces and boilers. Life-cycle cost consists of two main components: the first cost of buying and installing a furnace or boiler (in 2001\$), and the annual operating costs over the lifetime of the equipment, discounted to the present.

$$
\text { LCC }=\text { installation cost }+\sum_{n=1}^{\text {lifetime }} \frac{\text { operating } \cos t}{(1+\text { discount rate })^{n}}
$$

The calculation of LCC is done for a representative sample of houses, one house at a time, using appropriate values for the inputs each time. To account for uncertainty and variability in specific inputs such as lifetime and discount rate, we used a distribution of values with 
probabilities attached to each value. For each house, we sampled values of these inputs from the probability distributions. As a result, the analysis produces a range of LCCs. A distinct advantage of this approach is that one can identify the percentage of consumers achieving LCC savings or attaining certain payback values due to an increased efficiency standard, in addition to the average LCC savings or average payback for that standard.

The report by Lekov et $\mathrm{al}^{4}$ presented payback period calculations based on the DOE test procedure. The test procedure uses specific, prescribed values to calculate annual energy consumption. At the time the test procedure was written, these values were considered to be relatively typical of conditions in U.S. homes. In contrast, the LCC analysis estimates furnace and boiler energy consumption under field conditions for a sample of houses that is representative of U.S. homes. These conditions include outdoor climate during the heating and cooling season which influence the operating hours of the equipment.

To estimate the impact of improved efficiency across a wide range of households that use furnaces and boilers, we selected a sample of households from the 1997 Residential Energy Consumption Survey (RECS97). ${ }^{5}$ For each sample household, we estimated the energy consumption of furnaces or boilers, incorporating: (1) baseline design characteristics, and (2) design options that yield higher efficiencies. The estimation of energy consumption involved a consideration of the actual characteristics of the sample households (see Lutz et al. for a detailed discussion). For each sample household, we calculated the LCC for that household's furnace or boiler at a range of efficiency levels.

To account for the uncertainty and variability in the inputs to the LCC calculation for a given household and between different households, we used a Monte Carlo simulation. A Monte Carlo simulation uses a distribution of values to allow for variability and/or uncertainty on inputs for complex calculations. For each input, there is a distribution of values, with probabilities (weighting) attached to each value. Monte Carlo simulations sample input values randomly from the probability distributions.

For each product class, we calculated the LCC and PBP 10,000 times per Monte Carlo simulation run. For some variables, such as energy price and climate, each calculation used the values associated with each RECS house. For these variables, the RECS houses were sampled according to the weighting assigned to them by the Energy Information Administration (EIA). This weighting was designed to reflect the prevalence of various features in the national population of houses. Sampling according to the weighting means that some of the RECS houses are sampled more than once, and others may not be sampled at all. We used Microsoft Excel spreadsheets with Crystal Ball, an add-on software, ${ }^{\text {a }}$ to perform the Monte Carlo analysis.

The inputs to the LCC allow calculation of the first cost of the equipment, and the operating cost over the equipment lifetime. The inputs to the PBP calculation are the total

\footnotetext{
${ }^{a}$ http://www.decisioneering.com/crystal_ball/
} 
installed cost of the equipment to the customer and the first-year operating expenditures. The PBP uses the same inputs as the LCC analysis, except that the PBP calculation does not require electricity price trends and discount rates. Since the PBP is a "simple" payback, energy prices are required only for the year in which a new standard is to take effect-in this case, the year 2012. The energy prices used in the PBP calculation were the prices projected for 2012.

The change in LCC resulting from a change to higher-efficiency equipment is calculated relative to what equipment a house would have in the absence of any change in standards ( the base case). We used the current distribution of efficiencies in shipments for the year 2000 as the base case. Thus, some houses in the base case are assumed to purchase higher-efficiency furnaces, while others purchase furnaces at the minimum efficiency currently allowed.

We performed the calculations using a series of Microsoft Excel spreadsheets.

\subsection{Design Options}

We calculated the LCC of furnaces and boilers incorporating a variety of design options that increase efficiency. Figures 3.1-3.6 show the design options considered for each product class. The center trunk of the flow chart, shown in the heavily-lined boxes, shows the efficiencylevel improvements as indicated by AFUE. The baseline efficiency level occupies the bottom position on the flow chart. Branches off the efficiency level improvements indicate either design options to reduce electricity use or modulating designs, or both. Moving up the center trunk, the increased efficiency levels build on previous design changes. For example, the heat-exchanger area is incrementally bigger (Increased HX area) for each efficiency improvement for nonweatherized gas furnaces.

The acronyms used in the figures include HX (heat exchanger), ECM (electronically commutated motor), and PSC (permanent split capacitor motor). 


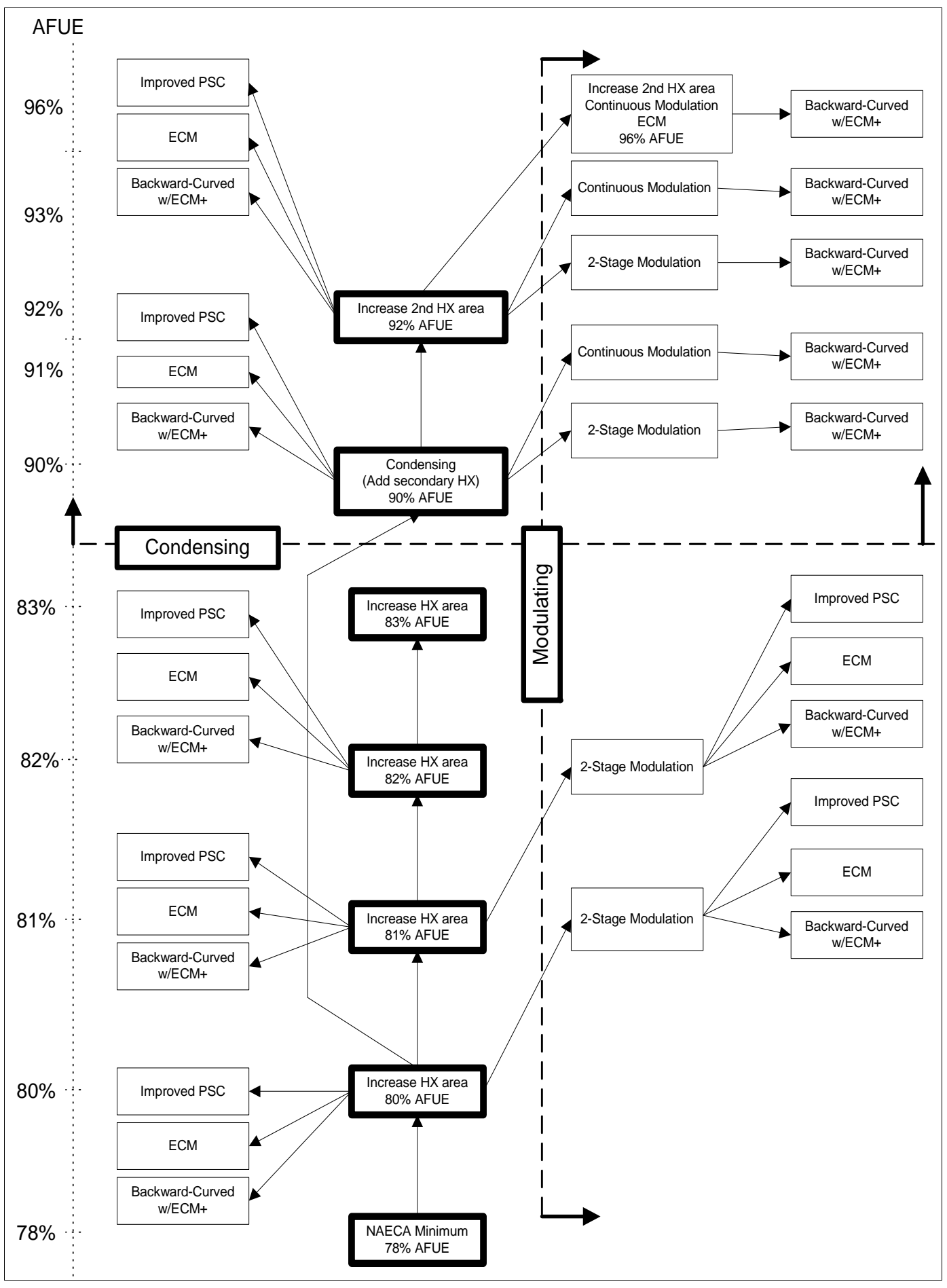

Figure 3.1 Non-Weatherized Gas Furnace LCC Analysis-Efficiency Levels and Design Options 


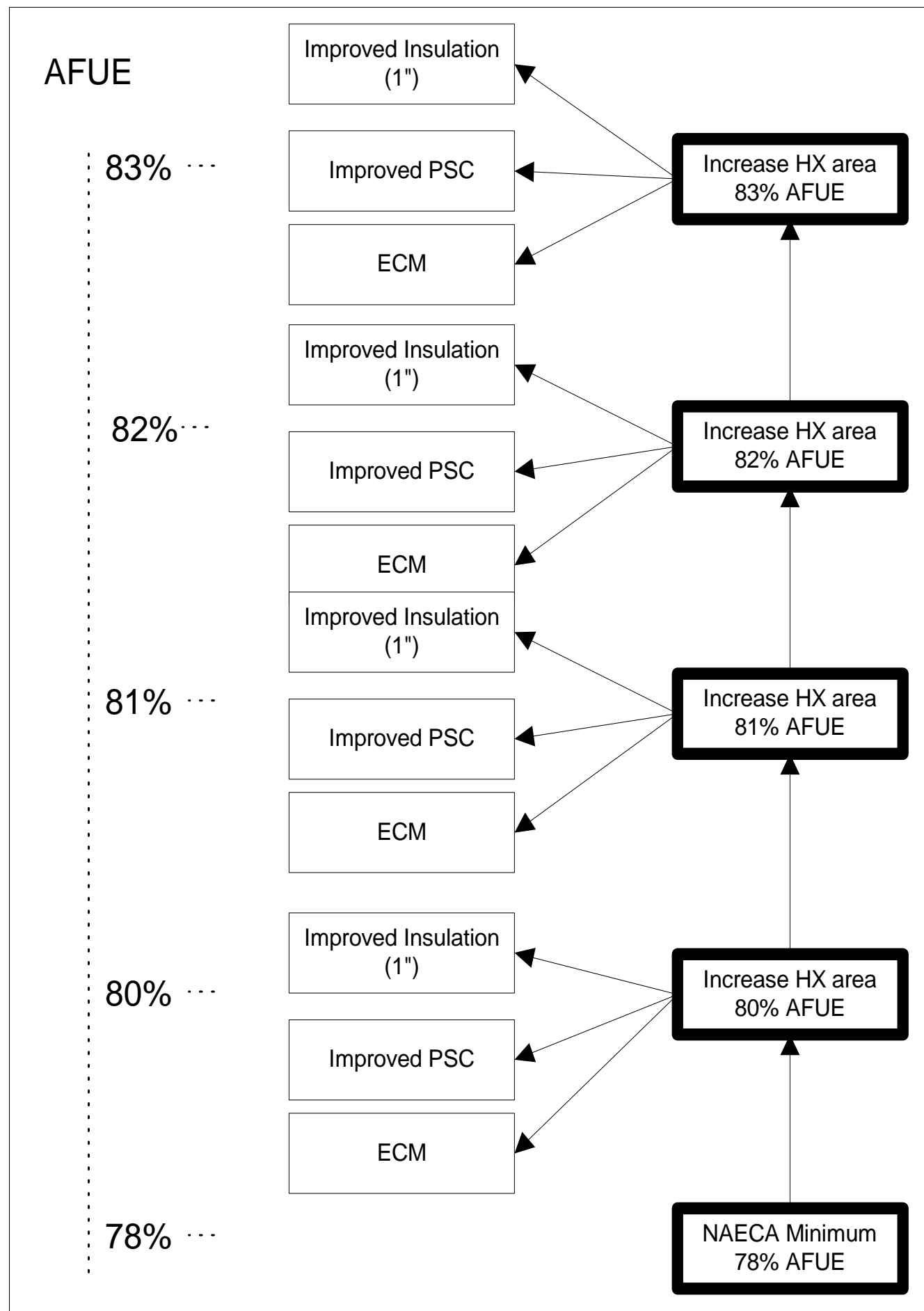

Figure 3.2 Weatherized Gas Furnace LCC Analysis-Efficiency Levels and Design Options 


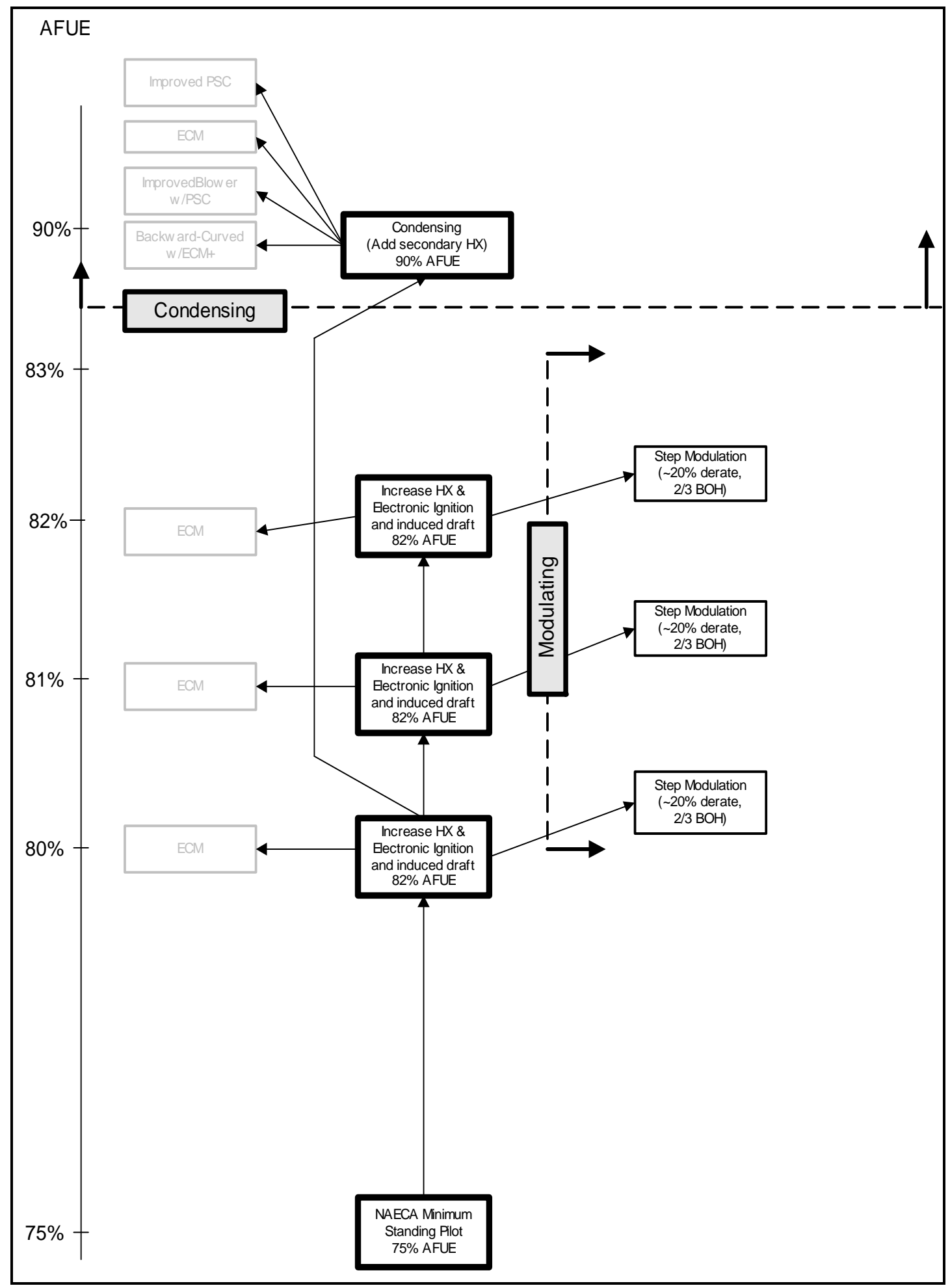

Figure 3.3 Manufactured Home Gas Furnace LCC Analysis-Efficiency Levels and Design Options 


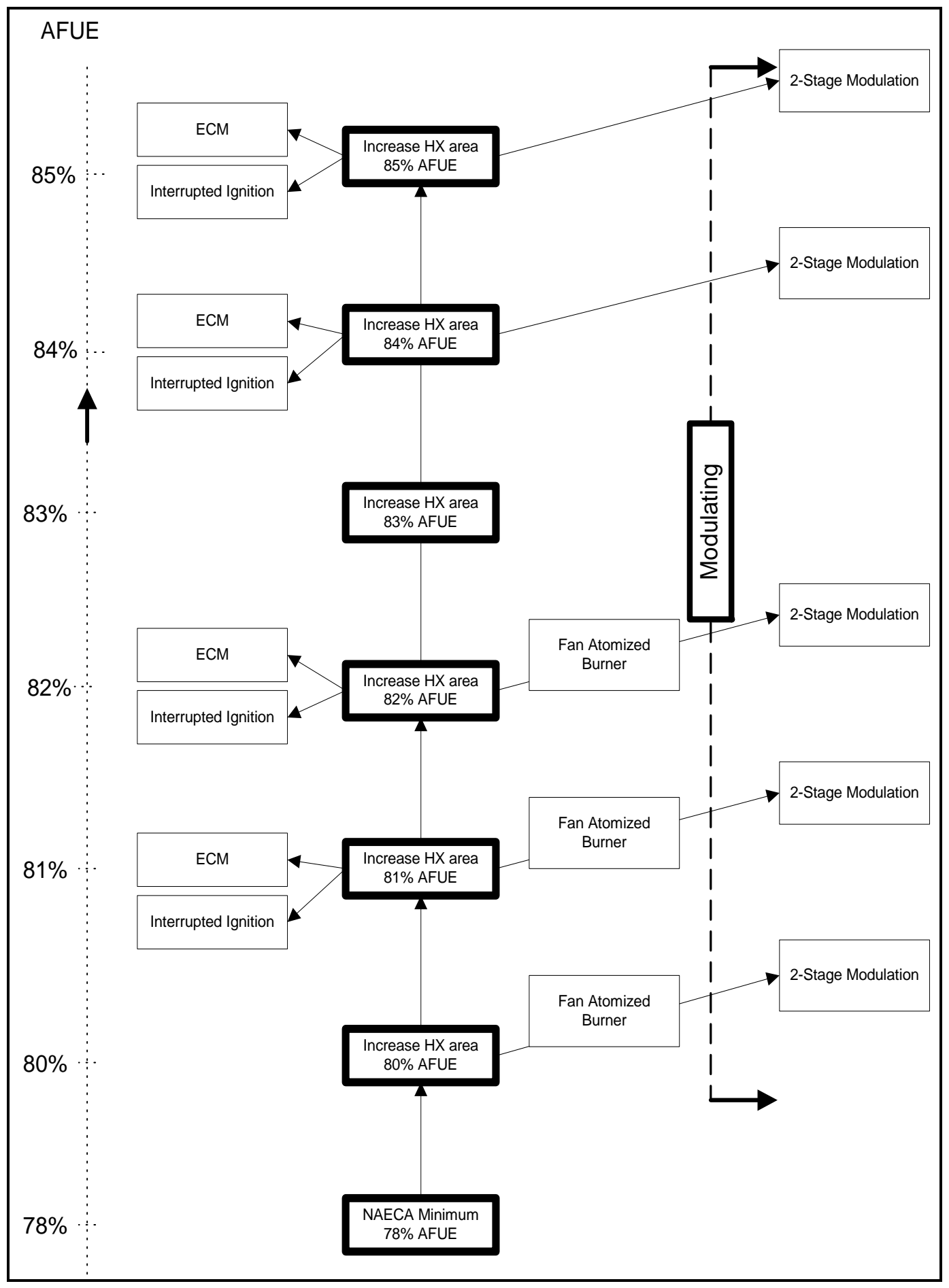

Figure 3.4 Oil-Fired Furnace LCC Analysis-Efficiency Levels and Design Options 


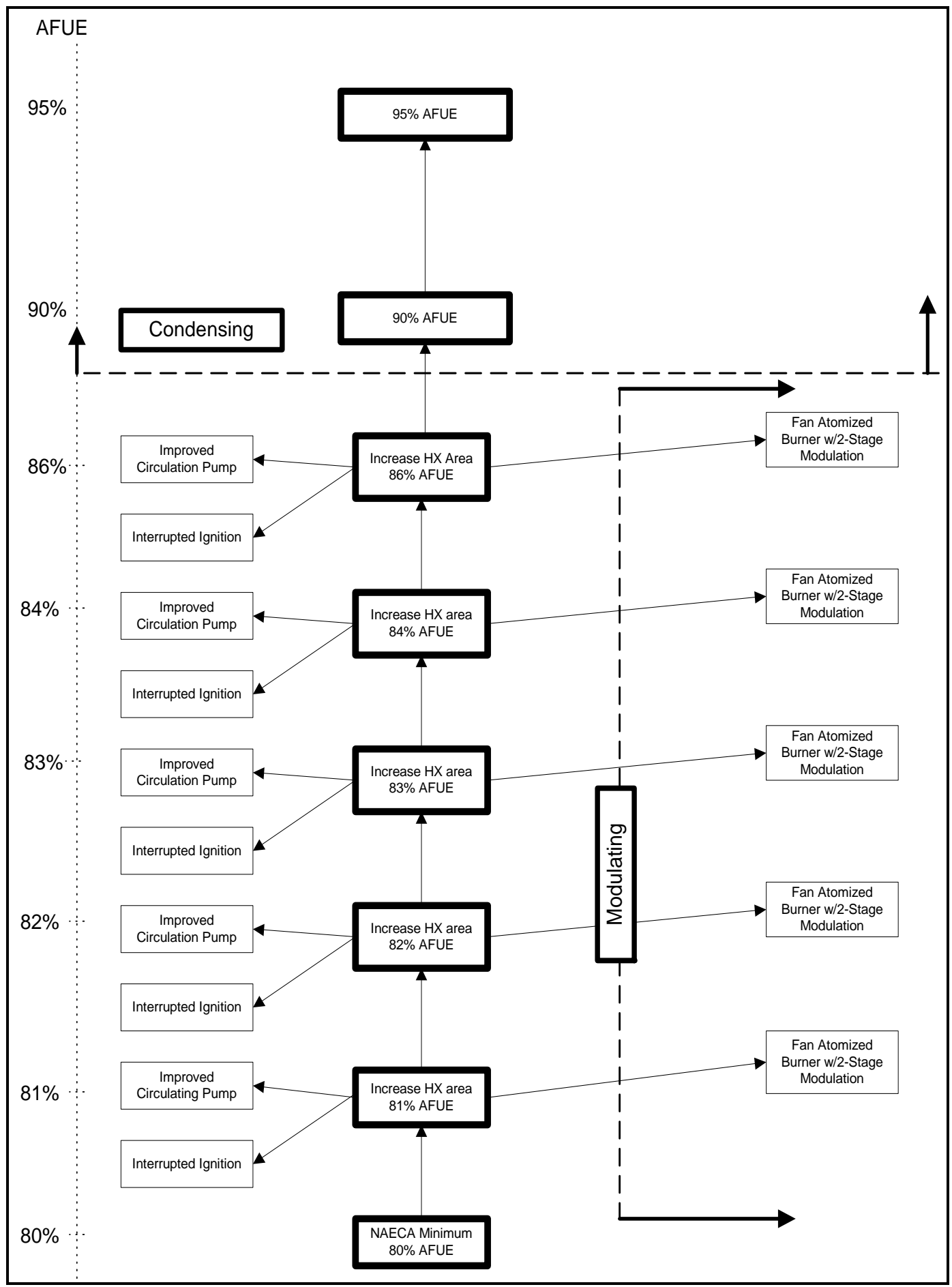

Figure 3.5 Hot-Water Oil Boiler LCC Analysis-Efficiency Levels and Design Options 


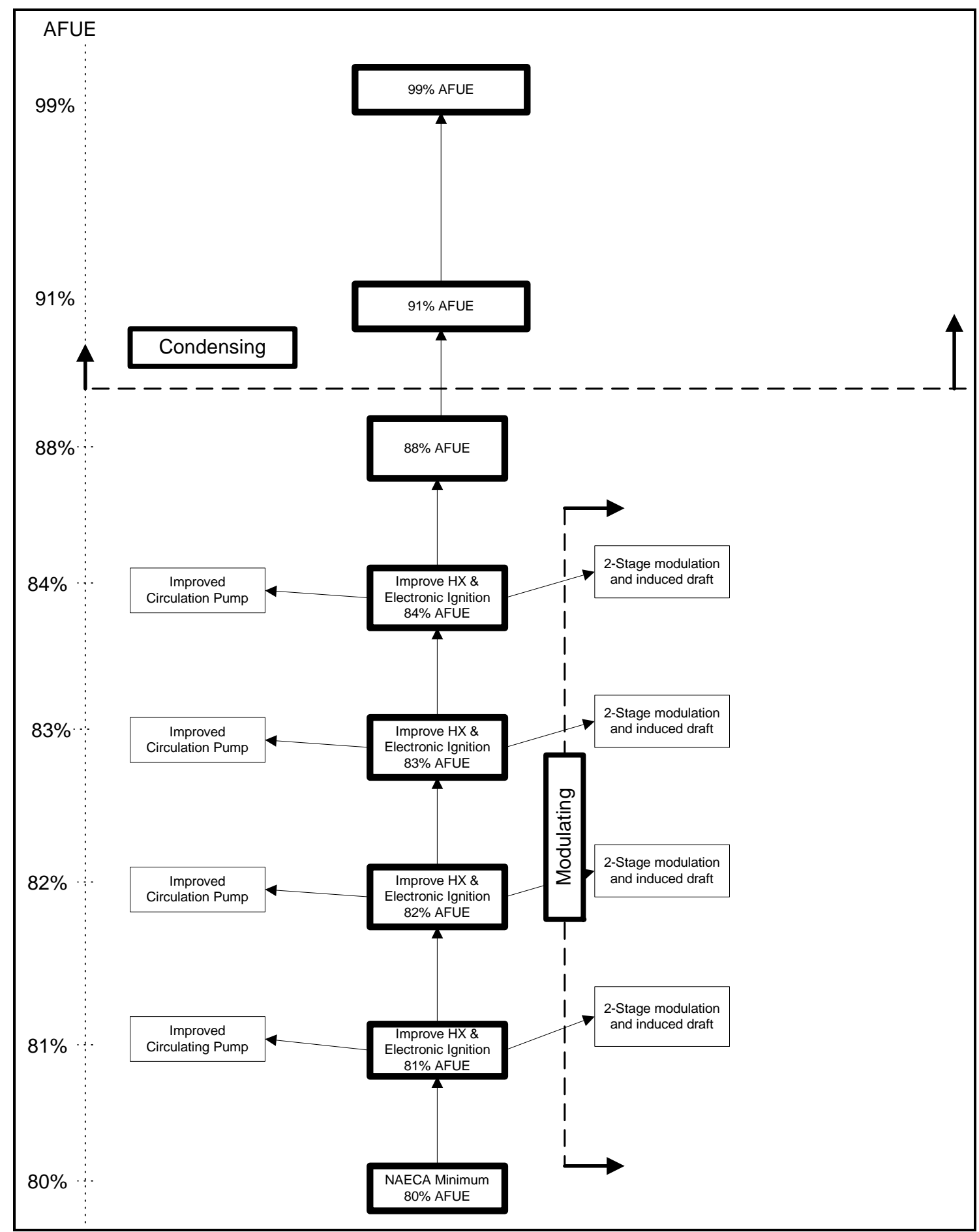

Figure 3.6 Hot-Water Gas Boiler LCC Analysis-Efficiency Levels and Design Options 


\subsection{Data Set for Calculating LCCs}

To assemble a representative sample of houses, we used a subset of records from the complete RECS97 data set that met all of the following criteria:

1) Use central heating equipment,

2) Use a boiler or furnace as the main source of heat,

3) Use a heating fuel that is natural gas, liquefied petroleum gas (LPG), or fuel oil, and

4) Heat only one housing unit.

The reason for criteria 4 is that we assumed any furnaces heating more than one unit would be larger than a residential furnace.

Of the 5900 houses surveyed in RECS97, 2313 housing records (38.5\% of the total weighted sample) had central, forced-air furnaces and met the above criteria; 560 housing records ( $8.5 \%$ of the weighted sample) had boilers and met the above criteria. The residential furnace and boiler subset represents $47 \%$ of the total houses in the United States (see Appendix A for the entire RECS97 subset).

We divided the RECS sample among the equipment product classes, using different algorithms (Table 3.1). We further divided the households with non-weatherized gas furnaces by census division and the four most populous states. 
Table 3.1 Criteria for Selection of RECS Household Data by Product Class

\begin{tabular}{|c|c|c|c|}
\hline Product Class & Algorithm & $\begin{array}{c}\text { \# of } \\
\text { Records }\end{array}$ & $\begin{array}{c}\text { \# of US Households } \\
\text { Represented (million) }\end{array}$ \\
\hline $\begin{array}{l}\text { Non-Weatherized Gas } \\
\text { Furnace }\end{array}$ & $\begin{array}{l}\text { Central heating equipment = furnace } \\
\text { Heating fuel = gas } \\
\text { Home type = single or multi-family } \\
\text { Number of Housing Units Heated = } 1\end{array}$ & 1986 & 37.3 \\
\hline $\begin{array}{l}\text { Weatherized }^{\mathrm{a}} \text { Gas } \\
\text { Furnace }\end{array}$ & $\begin{array}{l}\text { Central heating equipment = furnace } \\
\text { Heating fuel = gas } \\
\text { Central air conditioning = yes (packaged unit) } \\
\text { Home type = single or multi-family } \\
\text { Number of Housing Units Heated = } 1 \\
\text { Census Division = West or East South Central } \\
\text { Large State = California, Florida or Texas }\end{array}$ & 396 & 7.2 \\
\hline $\begin{array}{l}\text { Manufactured-Home } \\
\text { Gas Furnace }\end{array}$ & $\begin{array}{l}\text { Central heating equipment = furnace } \\
\text { Heating fuel = gas } \\
\text { Home type = manufactured home } \\
\text { Number of Housing Units Heated = } 1 \\
\text { House Vintage = less than } 1976\end{array}$ & 90 & 1.4 \\
\hline Oil-Fired Furnace & $\begin{array}{l}\text { Central heating equipment = furnace } \\
\text { Heating fuel = oil } \\
\text { Home type = single or multi-family } \\
\text { Number of Housing Units Heated = } 1\end{array}$ & 237 & 2.7 \\
\hline Gas Hot-Water Boiler ${ }^{\mathrm{c}}$ & $\begin{array}{l}\text { Central heating equipment = boiler } \\
\text { Heating fuel = gas } \\
\text { Home type = single or multi-family } \\
\text { Number of Housing Units Heated = } 1\end{array}$ & 315 & 5.2 \\
\hline Oil Hot-Water Boiler & $\begin{array}{l}\text { Central heating equipment = boiler } \\
\text { Heating fuel = oil } \\
\text { Home type = single or multi-family } \\
\text { Number of Housing Units Heated = } 1\end{array}$ & 245 & 3.4 \\
\hline
\end{tabular}

a Some of the same housing records are used for analyzing both weatherized and non-weatherized furnace product classes, because equipment placement within the building is not given in RECS97. To analyze weatherized furnaces, we looked at the subset of housing records that had gas furnaces and central air conditioners, and were located in the West South Central, East South Central Census divisions or in the states of California, Florida, or Texas.

b Federal regulation regarding manufactured housing construction changed the quality of the structures manufactured.

c Because RECS does not distinguish between steam and hot-water boilers, we assumed for the purposes of this analysis that all boilers in RECS are hot-water boilers. Hot-water boilers comprise $84 \%$ of gas boiler shipments and $88 \%$ of oil-fired boiler shipments ${ }^{6}$.

\subsubsection{New Construction versus Replacement Installations}

We treated a furnace or boiler in a new home differently from one purchased as replacement equipment for three reasons: 
1) Heating-equipment prices are different for new construction and retrofit applications. Equipment cost for new construction includes a builder markup and does not include sales tax. Equipment cost for replacement installations includes sales tax and does not include a builder markup.

2) The financing method (and therefore the discount rate in the LCC calculation) for new construction is usually a mortgage loan. Financing methods for replacement installations can take a variety of forms - e.g., cash, credit cards, home equity loans - that have different interest rates.

3) New construction tends to be built with more insulation and more energy-efficient products, compared to houses that receive replacement installations. New construction is also concentrated in certain parts of the country.

The share of equipment shipped to new construction varies depending on the product class. Table 3.2 shows the criteria used to determine which housing records were treated as new construction.

We estimated that $26 \%$ of non-weatherized gas furnaces go to new construction. We arrived at this figure by multiplying the number of housing starts in $1999(1,604,000)^{7}$ by the proportion of new houses with gas furnaces(51.2\%), and then dividing by of total gas furnace shipments in $1999(3,126,147)^{2}$. The vast majority of boilers and oil-fired furnaces are sold for replacement, we analyzed all oil-fired furnaces, gas boilers, and oil-fired boilers as replacements. We assumed that all manufactured-home gas furnaces were sold in new construction, as insufficient data were available about the replacement market for manufactured-home gas furnaces.

We divided the RECS sample houses into two subsets new construction or replacement. We assigned those houses constructed in the 5-year period prior to the RECS survey to the new construction subset, and houses built prior to 1992 to the replacement installation subset. ${ }^{a}$ The Monte Carlo analysis sampled 26\% of the iterations from the new construction subset and 74\% from the replacement installation subset. The analysis sampled markups and discount rates from the appropriate distributions depending on whether the sample house was drawn from the new construction or replacement subsets.

\footnotetext{
a We recognize that houses built in 1992-1996 are an imperfect proxy for newly-built houses in 2012. However, these were the only data points with sufficient detail for use in this analysis.
} 
Table 3.2 New Construction Share for Residential Furnaces and Boilers

\begin{tabular}{|l|l|c|}
\hline \multicolumn{1}{|c|}{ Product Class } & New Construction Subset Criterion & $\begin{array}{c}\text { \% of Total Class } \\
\text { Shipment }\end{array}$ \\
\hline Non-weatherized Gas Furnace & $\begin{array}{l}\text { Houses constructed in the 5-year } \\
\text { period 1992-1997 }\end{array}$ & $26 \%$ \\
\hline Weatherized Gas Furnace & $\begin{array}{l}\text { Houses constructed in the 5-year } \\
\text { period 1992-1997 }\end{array}$ & $26 \%$ \\
\hline Manufactured-Home Gas Furnace & $\begin{array}{l}\text { Houses constructed in the 10-year } \\
\text { period 1986-1997 }\end{array}$ & $0 \% \%$ \\
\hline Oil-Fired Furnace & $\begin{array}{l}\text { We assumed that no new construction } \\
\text { receives oil-fired furnaces }\end{array}$ & $0 \%$ \\
\hline Hot-Water Gas Boiler & $\begin{array}{l}\text { We assumed that no new construction } \\
\text { receives gas boilers }\end{array}$ & $0 \%$ \\
\hline Hot-Water Oil Boiler & $\begin{array}{l}\text { We assumed that no new construction } \\
\text { receives oil-fired boilers }\end{array}$ & \\
\hline
\end{tabular}

\section{$4 \quad$ INPUTS}

\subsection{First Cost Inputs}

The flow chart in Figure 4.1 represents the inputs for first cost. The chart represents both baseline and higher-efficiency equipment; however, the markups differ for baseline equipment and higher-efficiency equipment. The chart shown represents non-weatherized gas furnaces; other product classes differ slightly.

One of the key factors determining first cost is equipment size. We chose typical sizes of heating equipment that appear in US households (see Lutz et al. for more details ${ }^{7}$ ). We then determined manufacturing cost, using a reverse-engineering cost analysis and applied markups for each point along the distribution chain (see Lekov et al. for more details on the cost and markup analysis). ${ }^{8}$ The markup applied depended on the type of installation (i.e., in new construction or replacement). Installation costs are the final component of first cost.

The size of the equipment, the type of installation, and the installation costs depend on the households for which the equipment is bought. Characteristics listed in the RECS data set enabled us to make reasonable assumptions about these factors for each household in the analysis. 


\section{First Cost Equipment}

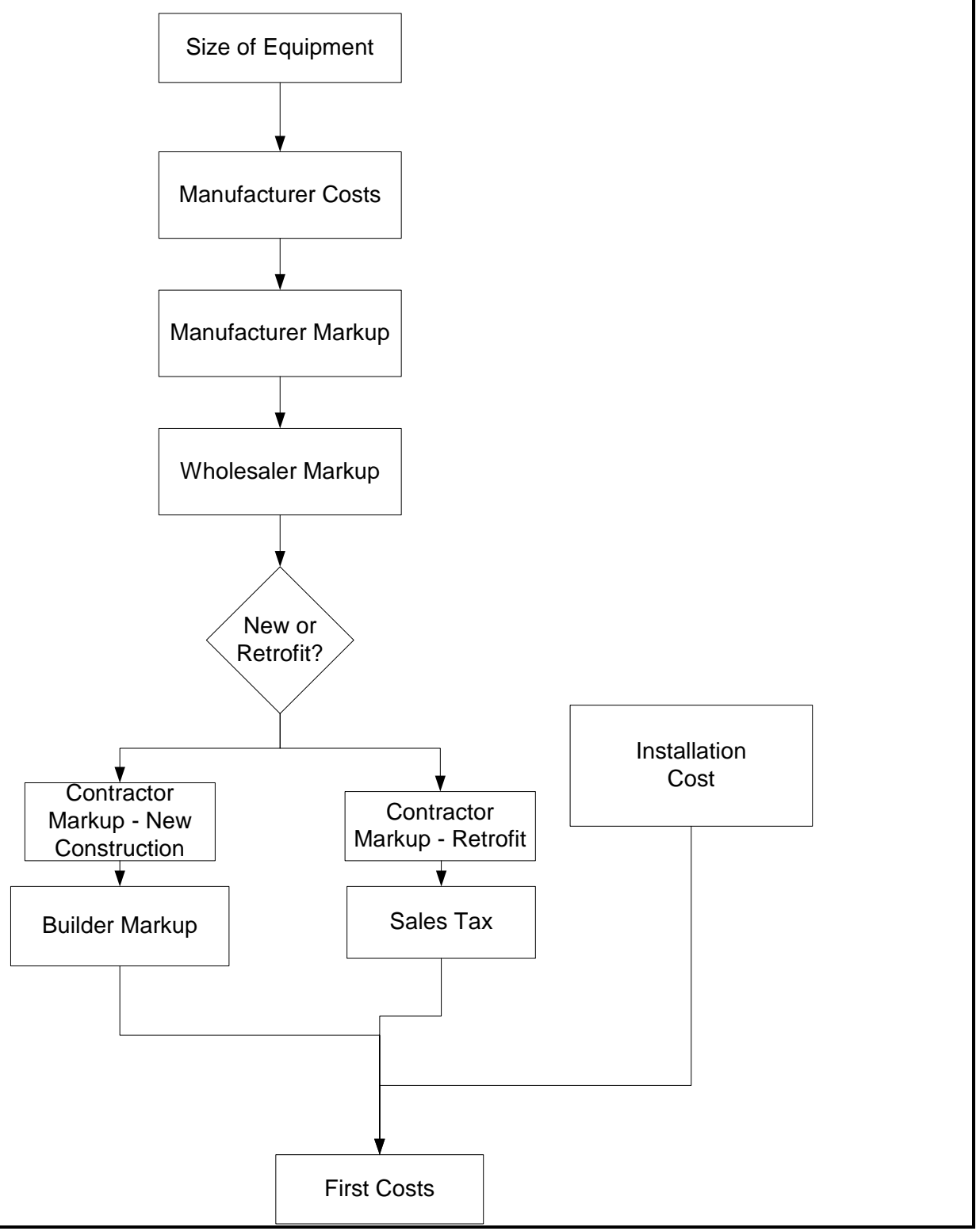

Figure 4.1 First Cost for Non-Weatherized Gas Furnaces 


\subsubsection{Manufacturing Cost}

We used manufacturing costs from a reverse-engineering cost analysis for one size of furnace or one size of boiler within each product class (see Lekov et al.). To derive the manufacturing costs for the other sizes, we scaled the reverse-engineered model costs.

Non-Weatherized Gas Furnace. To represent the majority of combinations of input capacity and nominal maximum airflow, we chose generic "virtual" models to represent 25 different combinations of those two variables. Each generic model had its own cost and energy characteristics. (See Lutz et al. for more details about generic models.) To develop the cost for each generic model, we reverse-engineered one model size (input capacity $=75 \mathrm{kBTU} / \mathrm{h}$ and airflow capacity $=3$ tons) and assigned costs for the different components. We scaled the cost for other input and capacity airflow capacities from the basic model cost for both noncondensing and condensing models. The generic models include models with the most commonly-occurring input capacities (Qin), with corresponding nominal maximum airflow rates at 0.5 inches water gauge. Figure 3.2 shows manufacturing costs by input capacity and airflow capacity for baseline, non-weatherized gas furnaces. The scalars used to adjust the cost from 75kBTU/h are found in the bottom row. Airflow capacities are in the left column.

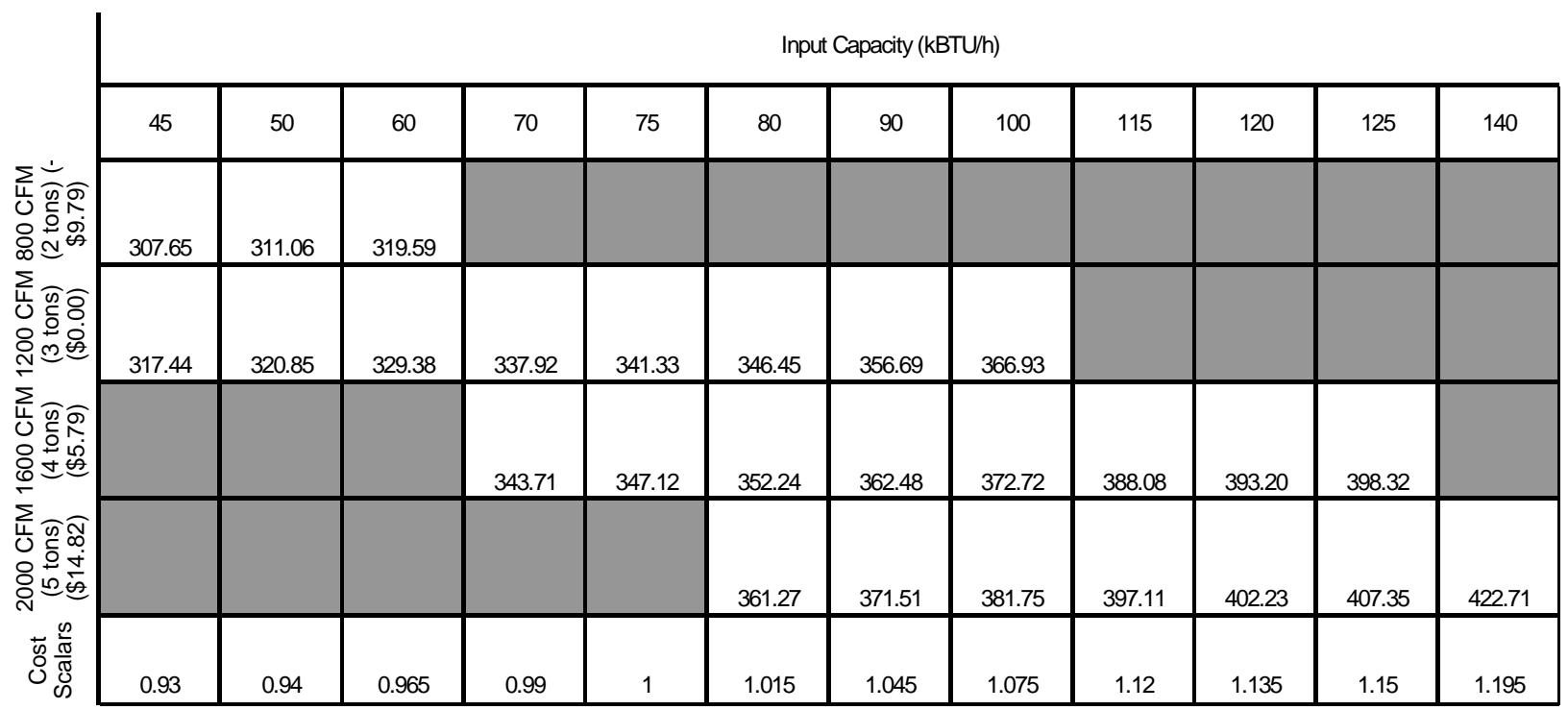

Figure 4.2 Manufacturing Costs (\$) for Baseline Non-Weatherized Furnaces by Input Capacity and Airflow Capacity

Other Product Classes. In the analysis of weatherized gas furnaces, we used the same generic models as in the analysis of non-weatherized gas furnaces. For manufactured-home furnaces and oil-fired furnaces, we used a subset of the 25 generic furnace models, because the market in those product classes is limited to a smaller number of sizes of furnaces. Tables 4.1-4.3 list the relevant sizes for weatherized gas, manufactured-home, and oil-fired furnaces. 
For the boiler product classes. We used the sizes of the generic models for non-weatherized gas furnaces, weighted to match the boiler sizes in the shipments data from GAMA.

Table 4.1 Relevant Sizes of Generic Models for Non-Weatherized and Weatherized Gas Furnaces

\begin{tabular}{|c|c|c|c|c|c|c|c|c|c|c|c|c|c|}
\hline \multicolumn{14}{|c|}{ Input Capacity (kBtu/h) } \\
\hline \multirow{5}{*}{ 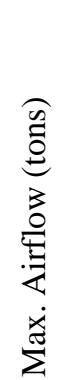 } & & 45 & 50 & 60 & 70 & 75 & 80 & 90 & 100 & 115 & 120 & 125 & 140 \\
\hline & 2 & $X$ & $\mathrm{X}$ & $\mathrm{X}$ & & & & & & & & & \\
\hline & 3 & $X$ & $X$ & $X$ & $X$ & $X$ & $\mathrm{X}$ & $\mathrm{X}$ & $X$ & & & & \\
\hline & 4 & & & & $\mathrm{X}$ & $\mathrm{X}$ & $X$ & $X$ & $\mathrm{X}$ & $X$ & $\mathrm{X}$ & $\mathrm{X}$ & \\
\hline & 5 & & & & & & & $X$ & $X$ & $X$ & $X$ & $X$ & $\mathrm{X}$ \\
\hline
\end{tabular}

Table 4.2 Relevant Sizes of Generic Models for Manufactured-Home Furnaces

\begin{tabular}{|c|c|c|c|c|c|c|c|c|c|c|c|}
\hline \multicolumn{12}{|c|}{ Input Capacity (kBtu/h) } \\
\hline \multirow{5}{*}{ 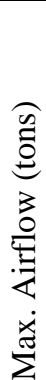 } & & 60 & 70 & 75 & 80 & 90 & 100 & 115 & 120 & 125 & 140 \\
\hline & 2 & $X$ & & $\mathrm{X}$ & & X & & & & & \\
\hline & 3 & $\mathrm{X}$ & & $\mathrm{X}$ & & $\mathrm{X}$ & & & & & \\
\hline & 4 & $\mathrm{X}$ & & $\mathrm{X}$ & & $\mathrm{X}$ & & & & & \\
\hline & 5 & $X$ & & $\mathrm{X}$ & & $\mathrm{X}$ & & & & & \\
\hline
\end{tabular}

Table 4.3 Relevant Sizes of Generic Models for Oil-Fired Furnaces

\begin{tabular}{|c|c|c|c|c|c|c|c|c|c|c|c|c|c|}
\hline \multicolumn{14}{|c|}{ Input Capacity (kBtu/h) } \\
\hline \multirow{5}{*}{ 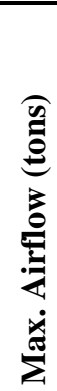 } & & 45 & 50 & 60 & 70 & 75 & 80 & 90 & 100 & 115 & 120 & 125 & 140 \\
\hline & 2 & & & & & & & & & & & & \\
\hline & 3 & & & & $\mathrm{X}$ & & & $\mathrm{X}$ & $\mathrm{X}$ & & & & \\
\hline & 4 & & & & & & & & $\mathrm{X}$ & & $\mathrm{X}$ & & \\
\hline & 5 & & & & & & & & $\mathrm{X}$ & & $\mathrm{X}$ & & $X$ \\
\hline
\end{tabular}

For weatherized gas furnaces, manufactured-home furnaces, and oil-fired furnaces, we scaled the cost for input sizes from the basic model cost for both non-condensing and condensing models. Table 4.4 shows the cost scalars that we used. We analyzed one size of boiler for both gas- and oil-fired boilers; therefore, scalars were not necessary. 
Table 4.4 Manufacturing Cost Scalars for Furnaces

\begin{tabular}{|c|c|c|}
\hline Input Capacity (kBtu) & AFUE $<$ 90\% & AFUE $\geq \mathbf{9 0 \%}$ \\
\hline 45 & 0.930 & 0.910 \\
50 & 0.940 & 0.925 \\
60 & 0.965 & 0.955 \\
70 & 0.990 & 0.985 \\
75 & 1.000 & 1.000 \\
80 & 1.015 & 1.020 \\
90 & 1.045 & 1.055 \\
100 & 1.075 & 1.090 \\
115 & 1.120 & 1.150 \\
120 & 1.135 & 1.170 \\
125 & 1.150 & 1.190 \\
140 & 1.195 & 1.240 \\
\hline
\end{tabular}

\subsubsection{Installation Cost}

The installation cost is the cost to the consumer of installing a furnace or a boiler; it is not considered part of the retail price. The cost of installation covers all labor associated with the installation of a new unit or the replacement of an existing one. This includes costs of changes to the house, such as venting modifications, that would be required for the installation.

Lekov et al. describe the approach for estimating installation costs. Such costs vary by efficiency level. For the LCC analysis, we assigned each household an installation cost from a distribution of values. Installation of higher-efficiency equipment may require use of more expensive "Category III" venting systems to prevent problems from condensation and boilers with an AFUE of 90\% or higher use "Category III" venting systems. For each efficiency level, Lekov et al. estimated the fraction of installations that would require such a venting system.

For the LCC analysis, we assigned each household an installation cost from a distribution of values for the appropriate venting system. For non-weatherized gas furnaces, oil-fired furnaces, and gas and oil boilers, the distribution was calculated with the Installation Model that DOE developed for this rulemaking. For weatherized gas furnaces, we used simplified calculations based on RS Means approach to calculate a mean value, and assigned a triangular distribution of $\pm 15 \%$ around the mean. For manufactured home furnaces, because they are installed at the manufactured home factory, the installation cost is included in the markup.

For non-weatherized gas furnaces, we calculated LCCs using each of the three sets of installation cost data described in Lekov et al. (the Installation Model developed by DOE, GRI, and NRCanada. For gas boilers, we calculated LCCs using the Installation Model and GRI costs. Alternative installation costs were not available for the other product classes.

The GRI costs are generally higher than the Installation Model costs, while the NRCanada costs are lower. They represent alternative costs that bound the potential range of 
installation costs. For the GRI data set, we used the distribution of values provided in the GRI report. For the NRCanada data set, which provided mean values, we assigned a triangular distribution of $\pm 15 \%$ around the mean.

\subsubsection{Finance Costs}

Many consumers purchase heating equipment with some type of financing. Calculations of the value of payments made over time should be discounted. Because we used the financingcost interest rate as the discount rate, the present value of the payments for consumers purchasing equipment over time is exactly the value of the equipment payments as if paid all at once. The Discount Rate section (4.4) discusses the assumptions regarding methods of financing for purchasing furnaces and boilers.

\subsection{Operating Cost Inputs}

Operating cost consists of energy and maintenance costs. The energy cost consists of separate costs for natural gas or oil, and electricity. Electricity is used for blower fans shared by furnaces and air conditioners, and in other components of fossil-fueled furnaces and boilers. The energy consumption calculations and results used in the LCC analysis are presented in Lutz et al.

\subsubsection{Energy Prices}

For all classes of gas equipment, we used the average energy price for each house to calculate the energy costs of base case equipment. We used marginal energy prices determined for each house for the cost of saved energy associated with higher-efficiency equipment. Marginal energy prices are the prices consumers pay for the last unit of energy used. Since marginal prices reflect a change in a consumer's bill associated with a change in energy consumed, such prices are appropriate for determining energy cost savings associated with efficiency standards.

For oil-fired furnaces and boilers, we used the average oil price for each house for both base case and higher-efficiency equipment, as the data necessary for estimating marginal prices were not available. We used the same method for LPG-fired equipment.

The LCC analysis requires information on the price of natural gas or heating oil during the winter, as well as the price of electricity used by electrical components. A furnace fan operates during the heating season and the cooling season. Since electricity prices vary by season in much of the country, we used different winter and summer electricity prices. We assumed that boilers are not operated during the summer months and, therefore, do not use electricity in the summer.

Calculating Energy Prices for RECS Households in 1998. We calculated average and marginal energy prices for each sample house in 1998 using RECS data. Along with RECS household data, EIA collects billing data (for up to 16 billing cycles) for a subset of households 
in the total RECS sample. For each household with billing data, the RECS data set includes, for each billing cycle: the start and end date, the electricity cost in dollars, the electricity consumption in $\mathrm{kWh}$, the natural gas bill in dollars, and the gas consumption in hundreds of cubic feet.

We estimated marginal energy prices from the RECS monthly billing data by calculating linear regression of monthly customer bills to monthly customer energy consumption for each household for which billing data were available. We interpreted the slope of the regression line for each household as the marginal energy price for that household for the season in question. ${ }^{9}$

To derive seasonal electricity prices, we divided the electricity billing data into summer and the rest of the year (non-summer). We considered a bill to be a summer bill if the midpoint of its billing period was in the four-month period from June 1 to September 30. We estimated the marginal electricity price for each season to be equal to the slope of the regression line for the billing data for that season. ${ }^{\mathrm{a}}$

We divided the natural gas billing data into two seasons: winter and the rest of the year. We considered a bill to be a winter bill if the midpoint of its billing period was in the four-month period from November 1 to February 28. Using the same $r^{2}$ cutoffs for the seasonal gas price regressions as for the electricity price regressions, we rejected $10 \%$ of the household gas billing data. Using these criteria, 2317 households with gas billing data had acceptable marginal price slopes; $66 \%$ of those households had acceptable seasonal data. We estimated annual marginal gas prices for the other $34 \%$ of the households in the same manner as it had for electricity prices.

For each household sampled from the RECS database, we identified the average electricity and gas prices - either from that household's data, if available, or from another nearby household. For the RECS subset used in this LCC analysis, we used 1740 housing records (of the 2317 housing records with natural gas price data and 2269 housing records with electricity price data.)

We calculated annual average LPG prices with data for RECS97 houses with LPG-fired equipment. Monthly data necessary to calculate marginal prices were not available for households using LPG heating. The same method was used for houses with oil-fired equipment.

\footnotetext{
a While the " $\mathrm{r}^{2}$ " values for the regressions of RECS electricity bills were generally very high, we eliminated some outliers by rejecting slopes (marginal prices) where the linear regression had an $r^{2}$ value less than 0.90 for either the summer or the non-summer. When acceptable slopes were not available for either season, we used the slope for the regression of all of the available billing cycles (unless the $\mathrm{r}^{2}$ value of the annualized slope was also less than 0.90). Based on this methodology, we rejected 8\% of the household electricity billing data. Using these criteria, 4396 households with electricity billing data had acceptable marginal price slopes; $79 \%$ of those households had acceptable seasonal data. For the remaining $21 \%$ of the households where both seasons did not have regression-line slopes with $r^{2}$ values greater than 0.90 , we used all of the monthly billing periods in combined form to estimate an annual marginal price.
} 
Projecting 1998 Prices to 2012 and Beyond. As in past DOE rulemaking, we used price forecasts by the EIA to estimate the trend in natural gas, oil, and electricity prices. We multiplied the average and marginal prices for 1998 of each sampled house by the forecast annual price changes in EIA's Annual Energy Outlook 2003 (AEO2003) to arrive at prices in 2012 and beyond. We calculated LCC and PBP using three separate projections from AEO2003: Reference, Low Economic Growth, and High Economic Growth. These three cases reflect the uncertainty of economic growth in the forecast period. The high and low growth cases show the projected effects of alternative growth assumptions on energy markets.

\subsubsection{Maintenance Cost}

Maintenance cost is the annual cost of maintaining a furnace or boiler in working condition. Each product class has distinct maintenance costs. Lekov et al. describe the approach for determining maintenance costs. Several groups of maintenance cost were developed, according to AFUE, for most of the product classes.

For the LCC analysis, we assumed a triangular distribution for maintenance costs to capture the variability of these costs. We assumed a minimum and maximum of $15 \%$ around the average.

\subsection{Lifetime}

The lifetime is the age at which furnaces or boilers are retired from service. Table 4.5 shows the lifetime range for the six product classes.

Table 4.5 Furnace and Boiler Lifetimes Used in the LCC Analysis (years)

\begin{tabular}{|l|c|c|c|}
\hline Product Class & Low & Average & High \\
\hline Non-Weatherized Gas Furnace* $^{*}$ & 10 & 20 & 30 \\
\hline Weatherized Gas Furnace* $^{*}$ & 12 & 18 & 24 \\
\hline Manufactured Home Furnace $^{\dagger}$ & 14 & 19 & 23 \\
\hline Oil-Fired Furnace* $^{*}$ & 10 & 15 & 20 \\
\hline Hot-Water Gas Boiler $^{\ddagger}$ & 13 & 17 & 22 \\
\hline Hot-Water Oil-Fired Boiler $^{\ddagger}$ & 12 & 15 & 19 \\
\hline
\end{tabular}

* Appliance Magazine ${ }^{10}$

† Mobile Home Technical Support Document, $1993^{11}$

† GRI, $1990^{12}$ 


\subsection{Discount Rates}

\subsubsection{Approach for Estimating Discount Rates}

We derived the discount rates for the LCC Analysis from estimates of the interest or "finance cost" to purchase furnaces or boilers. Following financial theory, the finance cost of raising funds to purchase furnaces or boilers can be interpreted as: (1) the financial cost of any debt incurred to purchase equipment, principally interest charges on debt, or (2) the opportunity cost of any equity used to purchase equipment, principally interest earnings on household equity.

Consumers use different financing methods to purchase equipment for new and existing homes. Furnaces or boilers purchased in new homes are financed with home mortgages.

Furnaces or boilers for existing homes (replacement equipment) are purchased using a variety of household debt and equity sources. In this analysis, we used different discount rates corresponding to the finance cost of new construction and replacement installations.

\subsubsection{Discount Rate Applied to New Housing Equipment}

We estimated the discount rate for new-house equipment based on mortgage interest rate data provided in the Survey of Consumer Finances (SCF) ${ }^{13}$. This survey indicates that mortgage rates carried by homeowners in 1998 averaged $7.9 \%$. This value is comparable to the average 1977-2001 first mortgage rate of 8.8\%. After adjusting for inflation and interest tax deduction, real after-tax interest rates on mortgages averaged $4.2 \%$. We assumed a $28 \%$ marginal income tax rate and $1.56 \%$ price inflation. (The median U.S. household income in 2000 was $\$ 43,162^{14}$. The marginal income tax of heads of households with this income is $27.5 \%{ }^{15}$. We rounded $27.5 \%$ to $28 \%$ for this analysis.) Price inflation reflects the change in the consumer price index (CPI) in 1998.

\subsubsection{Discount Rate Applied to Replacement Equipment}

We are not aware of any statistically-representative data that show how households use debt and equity in order to purchase a replacement furnace or boiler. Economic theory suggests that consumers maintain a balance of debt and equity in their portfolio that is not likely to change as a result of purchasing a furnace or boiler. Thus, we assumed that households draw on equity and debt to purchase replacement furnaces or boilers in proportion to the share of the different types of equity and debt holdings in U.S. households. We estimated the household equity and debt portfolio from the 1995 and 1998 SCF data, which indicate that the types of equity and debt likely to be affected by appliance purchases include second mortgages, credit cards, transaction accounts, certificates of deposit (CDs), U.S. savings bonds, stocks, and mutual funds.

We estimated interest or return rates associated with the household equity and debt holdings from a variety of sources. Rates for second mortgages and credit cards are from 1998 SCF data. We estimated interest rates associated with household CDs, treasury bills (T-bills), 
and corporate bonds as an average of the Federal Reserve Board time-series data covering 1977-2001. ${ }^{16}$ Based on relative returns to less-liquid assets, we assumed that the interest rate on transactions (checking) accounts averages $2 \%$ real. The $2 \%$ figure is based on an analysis of returns to money-market accounts and savings accounts, and returns to CD and bond holdings. We estimated annual return associated with household stock holdings as an average of data published by the Stern Business School covering the 1977-2001 period. ${ }^{17}$ We estimated mutual fund rates as an average of the Standard and Poor's (S\&P) 500 stock rate (67\%) and the T-bill rate $(33 \%)$.

Table 4.6 summarizes the shares of household equity and debt based on the above sources and the real, after-tax interest rates associated with each type of equity or debt. We assumed a marginal tax rate of $28 \%$ and CPI inflation to derive real from nominal values. The weighted-average real interest rate across all types of household debt and equity used to purchase replacement furnaces or boilers is $6.7 \%$.

Table 4.6 After-Tax Real Interest or Return Rates for Household Debt and Equity Types

\begin{tabular}{|l|c|c|}
\hline \multicolumn{1}{|c|}{ Type } & $\begin{array}{c}\text { Share of Household Debt } \\
\text { plus Equity (\%) }\end{array}$ & Mean Rate (\%) \\
\hline Second mortgage & 3.0 & 5.9 \\
\hline Credit card and installment & 9.1 & 12.0 \\
\hline Transaction (checking) accounts & 20.0 & 2.0 \\
\hline CD (6-month) & 7.9 & 2.8 \\
\hline Savings bonds (Treasury) & 1.6 & 3.7 \\
\hline Bonds (Corporate AAA) & 8.3 & 4.4 \\
\hline Stocks (S\&P500) & 30.2 & 9.6 \\
\hline Mutual funds & 19.8 & 7.6 \\
\hline Weighted-average discount rate & N/A & 6.7 \\
\hline
\end{tabular}

\subsubsection{Accounting for Variation in Discount Rates}

To account for variation in discount rates among consumers, we used the distribution of rates of interest or return on debt and equity among households. The data used to construct these distributions are provided in Appendix B for all finance methods except transactions accounts. The figures show the distribution of nominal rates obtained from the data sources previously mentioned. We calculated the real, after-tax rates as described in sections 4.4.2 and 4.4.3. The interest-rate distribution for transactions accounts is assumed to be triangular and to range from $0 \%$ to $4 \%$. 


\subsection{Payback Period Inputs}

The data inputs to the PBP calculation are the cost of the equipment to the customer and the annual (first-year) operating expenditures. The PBP calculation uses the same inputs as the LCC analysis, except that electricity price trends and discount rates are not required. Since the PBP is a "simple" payback, the required energy prices are only for the year in which a new standard is to take effect-in this case the year 2012. The energy prices used in the PBP calculation were the prices projected for that year.

The payback period equation can be expressed as:

$$
\text { Paybackopion }_{\text {ofios }}=\frac{\text { EquipCost }_{\text {option }}-\text { EquipCost }_{\text {base }}}{\text { OprCost }_{\text {base }}-\text { OprCost }_{\text {option }}}
$$

where base is the basecase design, and option is the design option being considered.

Numerically, the simple payback period is the ratio of the increase in purchase (and installation) price to the decrease in annual operating expenditures (including maintenance). We made the comparisons based on replacing the baseline furnace or boiler with a furnace or boiler incorporating another design option. Payback periods are expressed in years. A payback period of three years means that the increased purchase price for the energy-efficient furnace or boiler is equal to three times the value of reduced operating expenses in the year of purchase; in other words, the increased purchase price is recovered in three years because of lower operating expenses. Payback periods greater than the life of the product mean that the increased purchase price is never recovered in reduced operating expenses. Negative payback periods are not relevant and we disregarded them.

\section{$5 \quad$ RESULTS}

For each set of sample houses using equipment in a given product class, we calculated the average LCC savings and the median and average payback period for each of the design options. We calculated LCC savings and payback period relative to the base case equipment in that house, and then averaged these LCC savings for each design option.

As mentioned above, the base case assumes, in the absence of new standards, purchase of equipment reflecting current patterns with respect to efficiency. We sampled the AFUE of the baseline furnace assigned to each house from a distribution of AFUEs that is representative of shipments for the year 2000, and is correlated with climate. Therefore, the base case equipment is not limited to the baseline model. (For that reason, the average LCC savings are not equal to the difference between the LCC of a specific option and the LCC of the baseline equipment.) To some houses, we assigned furnaces that are more efficient than some of the design options. We assumed that a household would not replace higher-efficiency equipment with lowerefficiency equipment, and considered these as "no impact" cases, since they not be affected. 
Appendix C presents the LCC results for High Growth and Low Growth price projections for residential natural gas, fuel oil, and electricity.

\subsection{Non-Weatherized Gas Furnaces}

Table 5.1 shows the LCC and payback results for non-weatherized gas furnaces. The 81\% AFUE level using single-stage (8\% of installations use Category III venting system) shows basically no change (-\$3) in LCC impact. The 81\% AFUE level using 2-stage modulation (no Category III venting systems required) has a positive LCC savings of \$72. The positive LCC savings for the $81 \%$ two-stage modulation design are due, in part, to it having lower energy consumption than the single-stage furnace of the same AFUE. To estimate the energy use of this furnace under field conditions, we adopted the assumptions for two-stage modulation that appear in the DOE test procedure (see Lekov et al. for discussion of the issues concerning use of these assumptions). The 90\% AFUE condensing level has a negative LCC impact (-\$154).

At $80 \%$ and $81 \%$ AFUE levels, the improved PSC motor increases the LCC savings relative to designs with baseline equipment. The ECM and BC/ECM+ options have a negative effect on LCC.

Appendix D presents the LCC results for non-weatherized gas furnaces using the alternative installation costs. 
Table 5.1 LCC and PBP Results for Non-Weatherized Gas Furnaces

\begin{tabular}{|c|c|c|c|c|c|c|c|}
\hline \multirow{2}{*}{$\begin{array}{c}\text { Design Option } \\
\text { (AFUE and technology } \\
\text { description) }\end{array}$} & \multicolumn{5}{|l|}{ LCC } & \multicolumn{2}{|c|}{ Payback } \\
\hline & Average & $\begin{array}{l}\text { Average } \\
\text { Savings }\end{array}$ & $\begin{array}{l}\text { Net } \\
\text { Cost }\end{array}$ & $\begin{array}{c}\text { No } \\
\text { Impact* }\end{array}$ & $\begin{array}{c}\text { Net } \\
\text { Benefit }\end{array}$ & Median & Average** \\
\hline & $\$$ & $\$$ & $\%$ & $\%$ & $\%$ & years & years \\
\hline 78\% Baseline & $\$ 9,966$ & & & & & & \\
\hline $80 \%$ & $\$ 9,795$ & $\$ 0$ & $0 \%$ & $99 \%$ & $1 \%$ & 2.1 & 37.8 \\
\hline $80 \%$ PSC+ & $\$ 9,784$ & $\$ 7$ & $17 \%$ & $27 \%$ & $56 \%$ & 5.4 & 5.3 \\
\hline $80 \%$ ECM & $\$ 9,873$ & $-\$ 59$ & $60 \%$ & $27 \%$ & $14 \%$ & 23.0 & 33.7 \\
\hline $80 \%$ BC/ECM+ & $\$ 9,822$ & $-\$ 21$ & $51 \%$ & $27 \%$ & $23 \%$ & 17.2 & 26.3 \\
\hline 80\% 2-stage mod. & $\$ 9,718$ & $\$ 41$ & $33 \%$ & $27 \%$ & $40 \%$ & 8.6 & 13.5 \\
\hline 80\% 2-mod. ECM & $\$ 9,795$ & $-\$ 13$ & $48 \%$ & $27 \%$ & $26 \%$ & 15.4 & 21.1 \\
\hline 80\% 2-stage mod. BC/ECM+ & $\$ 9,782$ & $\$ 1$ & $45 \%$ & $27 \%$ & $28 \%$ & 14.3 & 20.9 \\
\hline $81 \%$ single stage, $8 \%$ Cat. III & $\$ 9,789$ & $-\$ 3$ & $32 \%$ & $27 \%$ & $41 \%$ & 8.8 & 27.8 \\
\hline 81\% PSC+ & $\$ 9,779$ & $\$ 5$ & $30 \%$ & $26 \%$ & $44 \%$ & 8.1 & 21.3 \\
\hline 81\% ECM & $\$ 9,868$ & $-\$ 62$ & $51 \%$ & $26 \%$ & $23 \%$ & 17.8 & 26.2 \\
\hline 81\% BC/ECM+ & $\$ 9,816$ & $-\$ 24$ & $45 \%$ & $26 \%$ & $29 \%$ & 14.8 & 22.9 \\
\hline 81\% 2-stage Mod, no Cat. III & $\$ 9,680$ & $\$ 63$ & $29 \%$ & $26 \%$ & $45 \%$ & 7.6 & 17.0 \\
\hline 81\% 2-stage Mod ECM & $\$ 9,795$ & $-\$ 20$ & $44 \%$ & $27 \%$ & $29 \%$ & 14.4 & 21.1 \\
\hline 81\% 2-stage Mod BC/ECM+ & $\$ 9,782$ & $-\$ 5$ & $43 \%$ & $26 \%$ & $31 \%$ & 13.7 & 20.5 \\
\hline $82 \%$ & $\$ 10,170$ & $-\$ 292$ & $70 \%$ & $26 \%$ & $4 \%$ & 28.7 & 84.6 \\
\hline $82 \%$ PSC+ & $\$ 10,159$ & $-\$ 284$ & $69 \%$ & $26 \%$ & $5 \%$ & 29.2 & 80.6 \\
\hline $82 \%$ ECM & $\$ 10,249$ & $-\$ 351$ & $71 \%$ & $26 \%$ & $3 \%$ & 48.4 & 102.4 \\
\hline $82 \%$ BC/ECM+ & $\$ 10,197$ & $-\$ 312$ & $68 \%$ & $26 \%$ & $6 \%$ & 34.8 & 80.3 \\
\hline 82\% 2-stage Mod & $\$ 10,103$ & $-\$ 256$ & $65 \%$ & $26 \%$ & $9 \%$ & 18.5 & 60.2 \\
\hline 82\% 2-stage Mod ECM & $\$ 10,179$ & $-\$ 310$ & $67 \%$ & $26 \%$ & $7 \%$ & 34.6 & 82.1 \\
\hline 82\% 2-stage Mod BC/ECM+ & $\$ 10,164$ & $-\$ 295$ & $65 \%$ & $26 \%$ & $9 \%$ & 30.9 & 70.4 \\
\hline $83 \%$ & $\$ 10,400$ & $-\$ 468$ & $73 \%$ & $26 \%$ & $1 \%$ & 63.3 & 121.3 \\
\hline 90\% Baseline Cond. & $\$ 9,917$ & $-\$ 154$ & $56 \%$ & $26 \%$ & $18 \%$ & 17.9 & 42.5 \\
\hline $90 \%$ PSC + & $\$ 9,907$ & $-\$ 145$ & $57 \%$ & $15 \%$ & $27 \%$ & 14.3 & 37.9 \\
\hline $90 \%$ ECM & $\$ 10,007$ & $-\$ 226$ & $66 \%$ & $15 \%$ & $19 \%$ & 21.5 & 47.0 \\
\hline $90 \%$ BC/ECM+ & $\$ 9,957$ & $-\$ 180$ & $63 \%$ & $15 \%$ & $22 \%$ & 19.1 & 42.0 \\
\hline 91\% 2-stage Mod ECM & $\$ 9,898$ & $-\$ 141$ & $58 \%$ & $15 \%$ & $26 \%$ & 16.5 & 40.6 \\
\hline
\end{tabular}




\begin{tabular}{|l|c|c|c|c|c|c|c|}
$91 \%$ 2-stage BC/ECM+ & $\$ 9,878$ & $-\$ 118$ & $58 \%$ & $15 \%$ & $27 \%$ & 16.2 & 37.8 \\
\hline $91 \%$ Step Mod ECM & $\$ 10,119$ & $-\$ 328$ & $67 \%$ & $15 \%$ & $18 \%$ & 22.2 & 54.2 \\
\hline 91\% Step Mod BC/ECM+ & $\$ 10,110$ & $-\$ 315$ & $66 \%$ & $15 \%$ & $18 \%$ & 21.6 & 49.2 \\
\hline 92\% Increased HX Area & $\$ 9,924$ & $-\$ 166$ & $60 \%$ & $15 \%$ & $25 \%$ & 16.1 & 41.7 \\
\hline 92\% PSC+ & $\$ 9,914$ & $-\$ 156$ & $63 \%$ & $2 \%$ & $35 \%$ & 13.2 & 35.8 \\
\hline 92\% ECM & $\$ 10,015$ & $-\$ 255$ & $76 \%$ & $2 \%$ & $22 \%$ & 21.3 & 45.0 \\
\hline 92\% BC/ECM+ & $\$ 9,965$ & $-\$ 205$ & $73 \%$ & $2 \%$ & $25 \%$ & 19.2 & 39.7 \\
\hline 93\% 2-stage Mod ECM & $\$ 9,912$ & $-\$ 154$ & $67 \%$ & $2 \%$ & $32 \%$ & 15.7 & 39.1 \\
\hline 93\% 2-stage Mod BC/ECM+ & $\$ 9,891$ & $-\$ 133$ & $66 \%$ & $2 \%$ & $32 \%$ & 15.7 & 35.7 \\
\hline 93\% Step Mod ECM & $\$ 10,134$ & $-\$ 373$ & $78 \%$ & $2 \%$ & $21 \%$ & 21.6 & 50.4 \\
\hline 93\% Step Mod BC/ECM+ & $\$ 10,124$ & $-\$ 362$ & $77 \%$ & $2 \%$ & $21 \%$ & 21.4 & 45.1 \\
\hline 96\% Step Mod ECM & $\$ 10,724$ & $-\$ 954$ & $89 \%$ & $2 \%$ & $9 \%$ & 32.3 & 88.9 \\
\hline 96\% Step Mod BC/ECM+ & $\$ 10,734$ & $-\$ 967$ & $91 \%$ & $0 \%$ & $9 \%$ & 32.8 & 83.6 \\
\hline
\end{tabular}

"No impact" means that the base case furnace assigned to the household has greater efficiency than the level indicated, so the household is not affected.

** $\quad$ From the form of the payback calculation, a very small change in operating cost can result in extremely large paybacks. These extremely large paybacks will skew the average payback. In these cases, median is probably a better indicator. 
Figure 5.1 shows the range of LCC savings among households for non-weatherized gas furnaces for a subset of the options in Table 5.1. For each design option, the top and the bottom of the box indicate the $75^{\text {th }}$ and $25^{\text {th }}$ percentiles, respectively. The bar at the middle of the box indicates the median; 50\% of the households have LCC savings above this value. The 'whiskers' at the bottom and the top of the box indicate the $5^{\text {th }}$ and $95^{\text {th }}$ percentiles. The small box shows the average LCC savings for each design option. The long tails on many of the $81 \%$ AFUE designs reflect the use of expensive Category III venting systems in some of the households. For condensing design options, such as 90\% AFUE and 92\% AFUE, the wide range of LCC savings reflects the differences in cost-effectiveness across regions of the country.

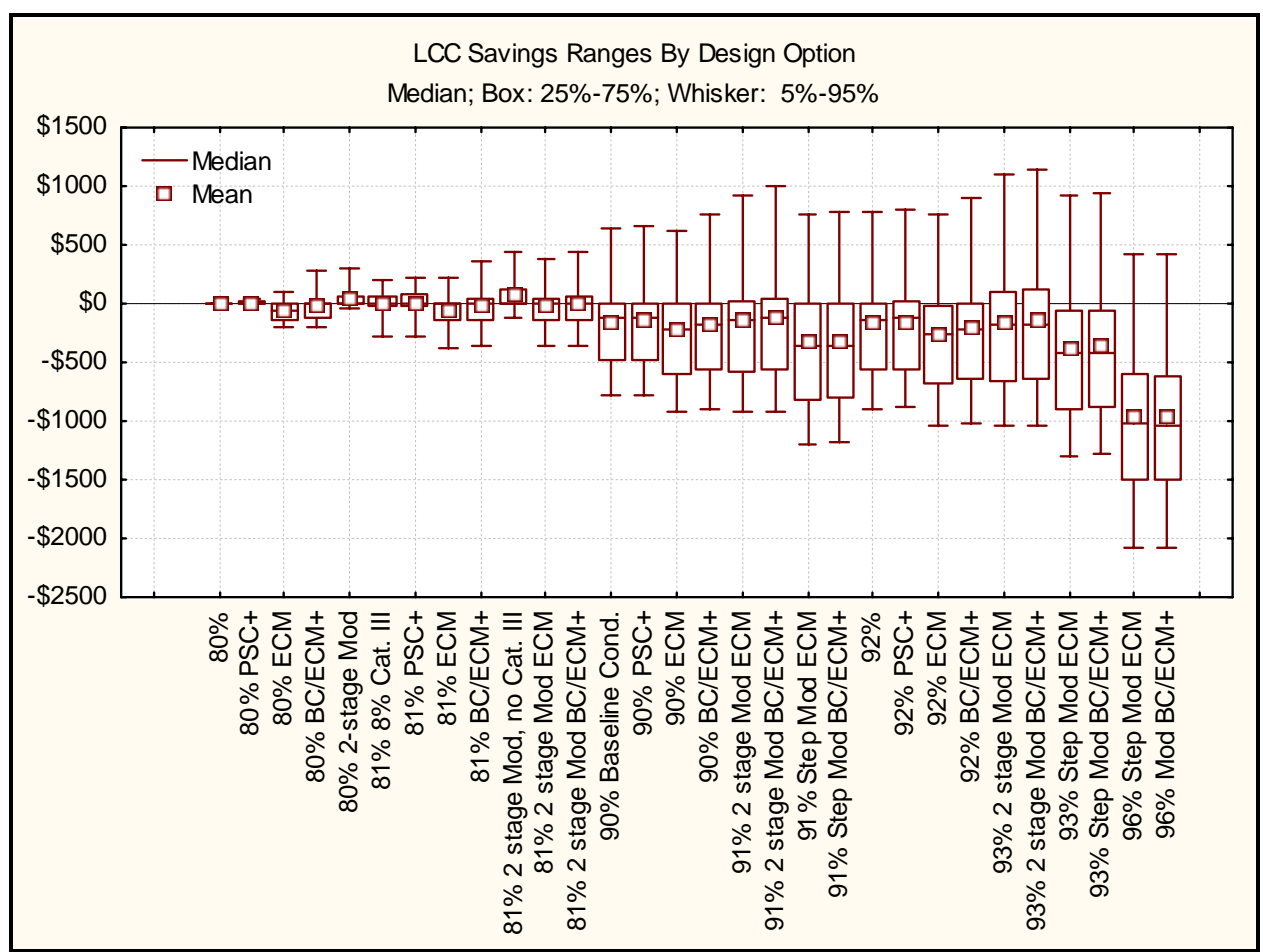

Figure 5.1 Range of LCC Savings by Design Option for NonWeatherized Gas Furnaces 
Figure 5.2 shows the range of LCC savings for each census division for the $90 \%$ AFUE condensing furnace. Only New England shows clearly positive mean savings.

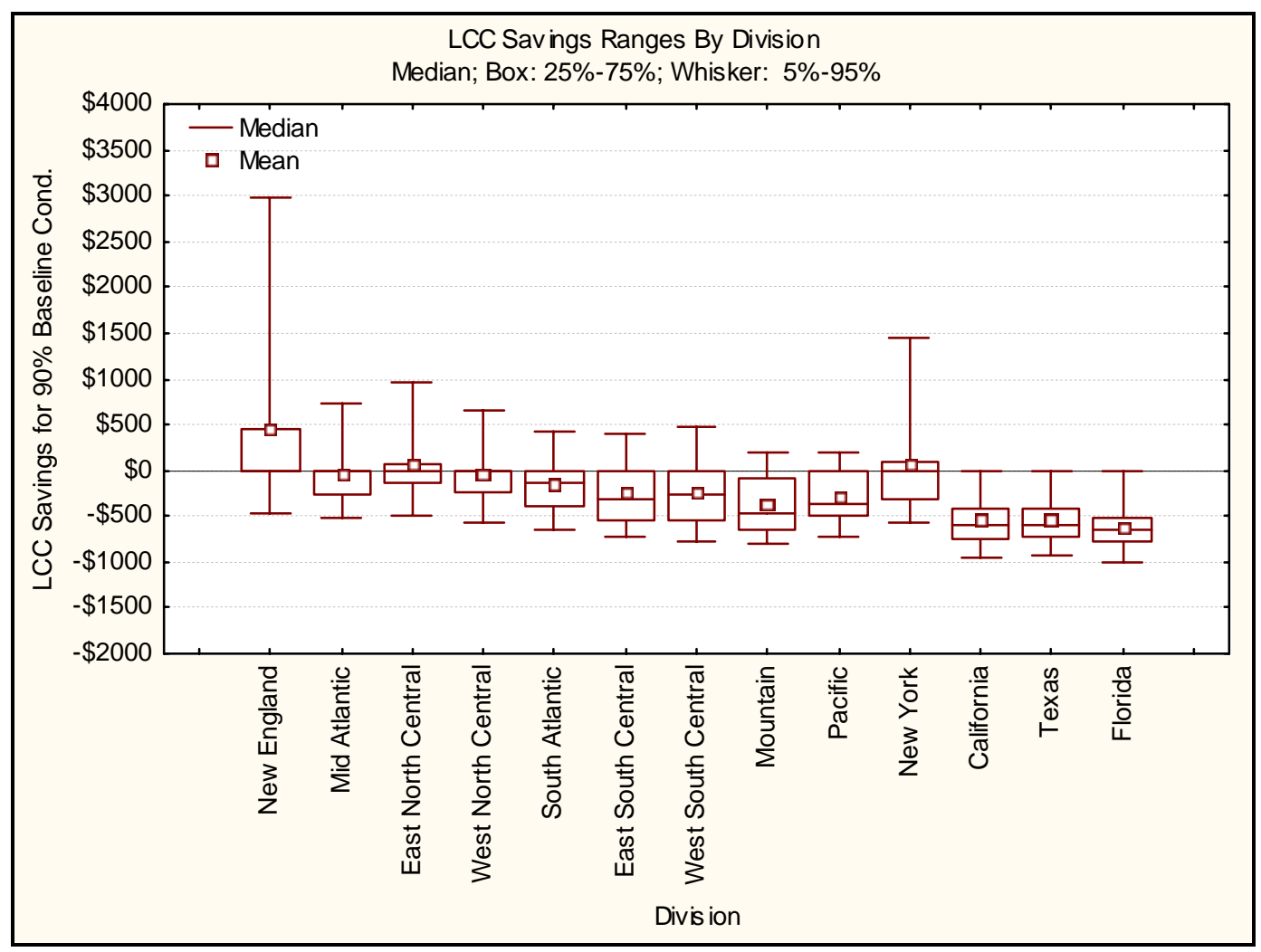

Figure 5.2 LCC Savings for Each Census Division for the 90\% AFUE Condensing Furnace

\subsection{Other Product Classes}

For weatherized gas furnaces (Table 5.2), the results show average LCC savings for AFUE levels through 83\%. For all considered AFUE levels, the improved PSC motor increases the LCC savings relative to designs with a baseline blower. The ECM option has a negative effect on LCC. Figure 5.3 shows the range of LCC savings by design option for weatherized gas furnaces. 
Table 5.2 LCC and PBP Results for Weatherized Gas Furnaces

\begin{tabular}{|c|c|c|c|c|c|c|c|}
\hline \multirow{2}{*}{$\begin{array}{c}\text { Design Option } \\
\text { (AFUE and technology } \\
\text { description) }\end{array}$} & \multicolumn{5}{|c|}{ LCC } & \multicolumn{2}{|c|}{ Payback } \\
\hline & Average & $\begin{array}{c}\text { Average } \\
\text { Savings }\end{array}$ & $\begin{array}{l}\text { Net } \\
\text { Cost }\end{array}$ & $\begin{array}{c}\text { No } \\
\text { Impact* }\end{array}$ & $\begin{array}{c}\text { Net } \\
\text { Benefit }\end{array}$ & Median & $\begin{array}{c}\text { Average* } \\
*\end{array}$ \\
\hline 78\% Baseline & $\$ 8,545$ & & & & & & \\
\hline 80\% Increased HX Area & $\$ 8,457$ & $\$ 2$ & $0 \%$ & $98 \%$ & $2 \%$ & 1.1 & 1.5 \\
\hline 80\% Improved Insulation & $\$ 8,454$ & $\$ 4$ & $26 \%$ & $46 \%$ & $28 \%$ & 9.0 & 8.2 \\
\hline $80 \%$ PSC+ & $\$ 8,441$ & $\$ 10$ & $6 \%$ & $46 \%$ & $48 \%$ & 3.4 & 4.0 \\
\hline $80 \%$ ECM & $\$ 8,529$ & $-\$ 37$ & $43 \%$ & $46 \%$ & $11 \%$ & 19.3 & 26.7 \\
\hline 80\% Improved Heat Transfer & $\$ 8,467$ & $-\$ 4$ & $52 \%$ & $46 \%$ & $2 \%$ & 2.8 & 3.7 \\
\hline 81\% Increased HX Area & $\$ 8,418$ & $\$ 23$ & $2 \%$ & $46 \%$ & $52 \%$ & 2.0 & 2.6 \\
\hline 81\% Improved Insulation & $\$ 8,415$ & $\$ 25$ & $20 \%$ & $20 \%$ & $60 \%$ & 5.2 & 6.4 \\
\hline $81 \%$ PSC+ & $\$ 8,402$ & $\$ 36$ & $4 \%$ & $20 \%$ & $76 \%$ & 2.8 & 3.4 \\
\hline 81\% ECM & $\$ 8,490$ & $-\$ 35$ & $58 \%$ & $20 \%$ & $22 \%$ & 16.0 & 21.2 \\
\hline 81\% Improved Heat Transfer & $\$ 8,424$ & $\$ 18$ & $32 \%$ & $20 \%$ & $48 \%$ & 3.8 & 5.1 \\
\hline 82\% Increased HX Area & $\$ 8,380$ & $\$ 53$ & $3 \%$ & $20 \%$ & $77 \%$ & 2.1 & 2.9 \\
\hline 82\% Improved Insulation & $\$ 8,377$ & $\$ 56$ & $18 \%$ & $0 \%$ & $82 \%$ & 4.3 & 5.6 \\
\hline $82 \%$ PSC+ & $\$ 8,364$ & $\$ 69$ & $4 \%$ & $0 \%$ & $96 \%$ & 2.6 & 3.2 \\
\hline $82 \%$ ECM & $\$ 8,452$ & $-\$ 19$ & $65 \%$ & $0 \%$ & $35 \%$ & 14.1 & 18.3 \\
\hline 82\% Improved Heat Transfer & $\$ 8,382$ & $\$ 51$ & $24 \%$ & $0 \%$ & $76 \%$ & 2.5 & 3.4 \\
\hline 83\% Increased HX Area & $\$ 8,347$ & $\$ 86$ & $6 \%$ & $0 \%$ & $94 \%$ & 2.9 & 3.9 \\
\hline 83\% Improved Insulation & $\$ 8,345$ & $\$ 88$ & $11 \%$ & $0 \%$ & $89 \%$ & 3.9 & 5.5 \\
\hline $83 \%$ PSC+ & $\$ 8,331$ & $\$ 102$ & $3 \%$ & $0 \%$ & $97 \%$ & 3.0 & 3.6 \\
\hline 83\% ECM & $\$ 8,420$ & $\$ 13$ & $58 \%$ & $0 \%$ & $43 \%$ & 12.2 & 15.0 \\
\hline 83\% Improved Heat Transfer & $\$ 8,345$ & $\$ 89$ & $4 \%$ & $0 \%$ & $96 \%$ & 2.4 & 3.3 \\
\hline
\end{tabular}

"No impact" means that the base case furnace assigned to the household has greater efficiency than the level indicated, so the household is not affected.

** $\quad$ From the form of the payback calculation, a very small change in operating cost can result in extremely large paybacks. These extremely large paybacks will skew the average payback. In these cases, median is probably a better indicator. 


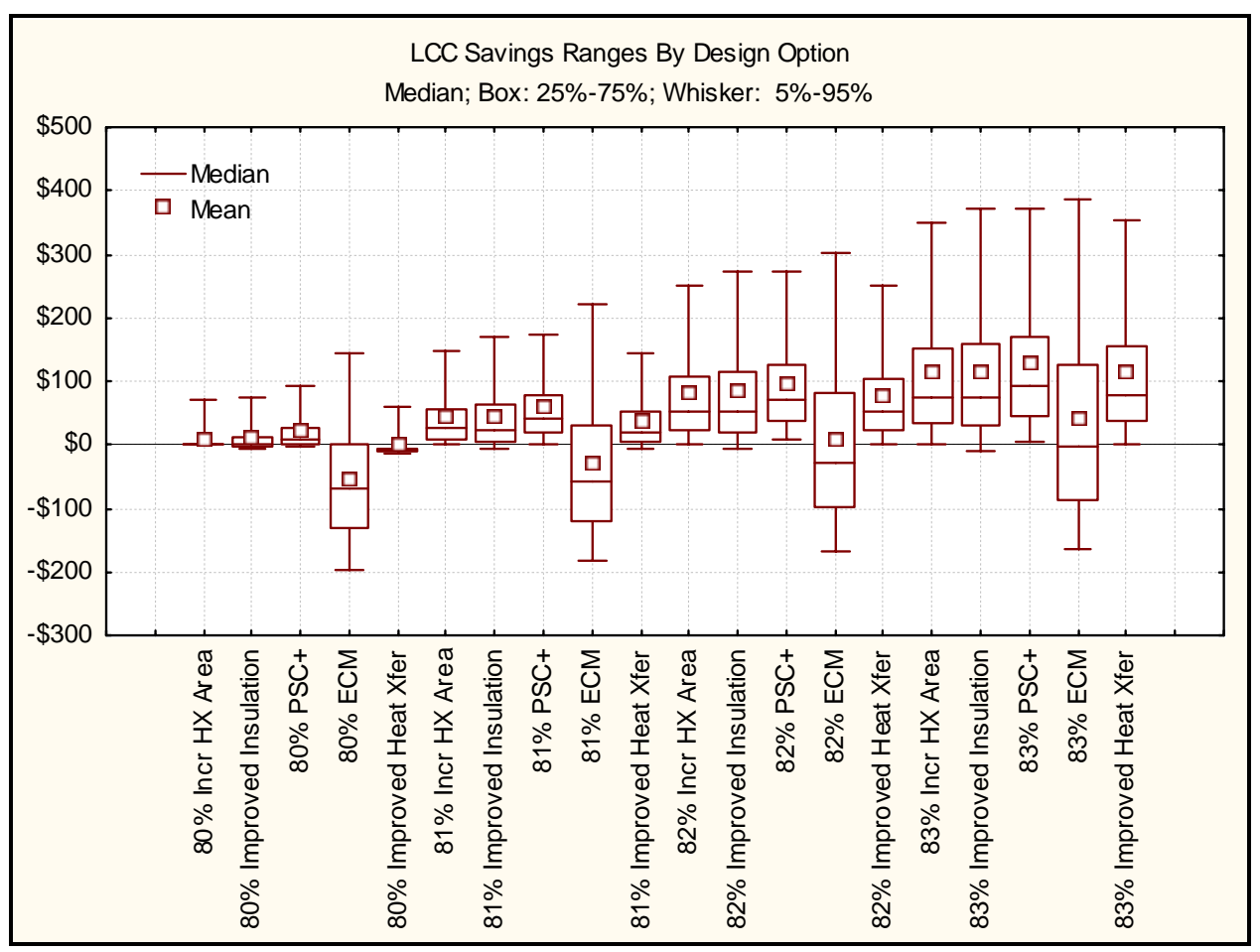

Figure 5.3 Range of LCC Savings by Design Option for Weatherized Gas Furnaces 
For manufactured-home gas furnaces (Table 5.3), the results show positive average LCC savings for the $81 \%$ and $82 \%$ AFUE levels. The $90 \%$ AFUE condensing level shows an average LCC savings of \$192, but nearly half of the households have a negative impact. The ECM option has a negative effect on LCC. Figure 5.4 shows the range of LCC savings by design option for manufactured-home gas furnaces.

Table 5.3 LCC and PBP Results for Manufactured-Home Gas Furnaces

\begin{tabular}{|l|c|c|c|c|c|c|c|}
\hline & \multicolumn{3}{|c|}{ LCC } & \multicolumn{3}{c|}{ Payback } \\
\hline $\begin{array}{c}\text { Design Option } \\
\text { (AFUE and technology } \\
\text { description }\end{array}$ & $\begin{array}{c}\text { Average } \\
\text { LCC }\end{array}$ & $\begin{array}{c}\text { Average } \\
\text { Savings }\end{array}$ & Net Cost & $\begin{array}{c}\text { No } \\
\text { Impact* }\end{array}$ & $\begin{array}{c}\text { Net } \\
\text { Benefit }\end{array}$ & Median & Average** \\
\hline $75 \%$ Baseline & $\$ 7,904$ & & & & & & \\
\hline $80 \%$ & $\$ 7,480$ & $\$ 64$ & $1 \%$ & $85 \%$ & $14 \%$ & 2.4 & 4.7 \\
\hline $80 \%$ ECM & $\$ 7,568$ & $-\$ 21$ & $67 \%$ & $5 \%$ & $28 \%$ & 20.0 & 36.1 \\
\hline $80 \%$-stage modulation & $\$ 7,718$ & $-\$ 163$ & $80 \%$ & $5 \%$ & $15 \%$ & 26.0 & 60.5 \\
\hline $81 \%$ & $\$ 7,428$ & $\$ 112$ & $10 \%$ & $5 \%$ & $85 \%$ & 4.4 & 6.3 \\
\hline $81 \%$ ECM & $\$ 7,517$ & $\$ 28$ & $57 \%$ & $5 \%$ & $38 \%$ & 15.6 & 21.2 \\
\hline $81 \% 2$-stage modulation & $\$ 7,670$ & $-\$ 117$ & $75 \%$ & $5 \%$ & $20 \%$ & 24.9 & 60.3 \\
\hline $82 \%$ & $\$ 7,385$ & $\$ 153$ & $14 \%$ & $5 \%$ & $81 \%$ & 5.1 & 7.5 \\
\hline $82 \%$ ECM & $\$ 7,473$ & $\$ 69$ & $49 \%$ & $5 \%$ & $46 \%$ & 13.3 & 17.4 \\
\hline $82 \%$ 2-stage modulation & $\$ 7,630$ & $-\$ 80$ & $70 \%$ & $5 \%$ & $25 \%$ & 22.9 & 56.3 \\
\hline $90 \%$ & $\$ 7,352$ & $\$ 184$ & $46 \%$ & $5 \%$ & $49 \%$ & 12.5 & 22.7 \\
\hline
\end{tabular}

"No impact" means that the base case furnace assigned to the household has greater efficiency than the level indicated, so the household is not affected.

** From the form of the payback calculation, a very small change in operating cost can result in extremely large paybacks. These extremely large paybacks will skew the average payback. In these cases, median is probably a better indicator. 


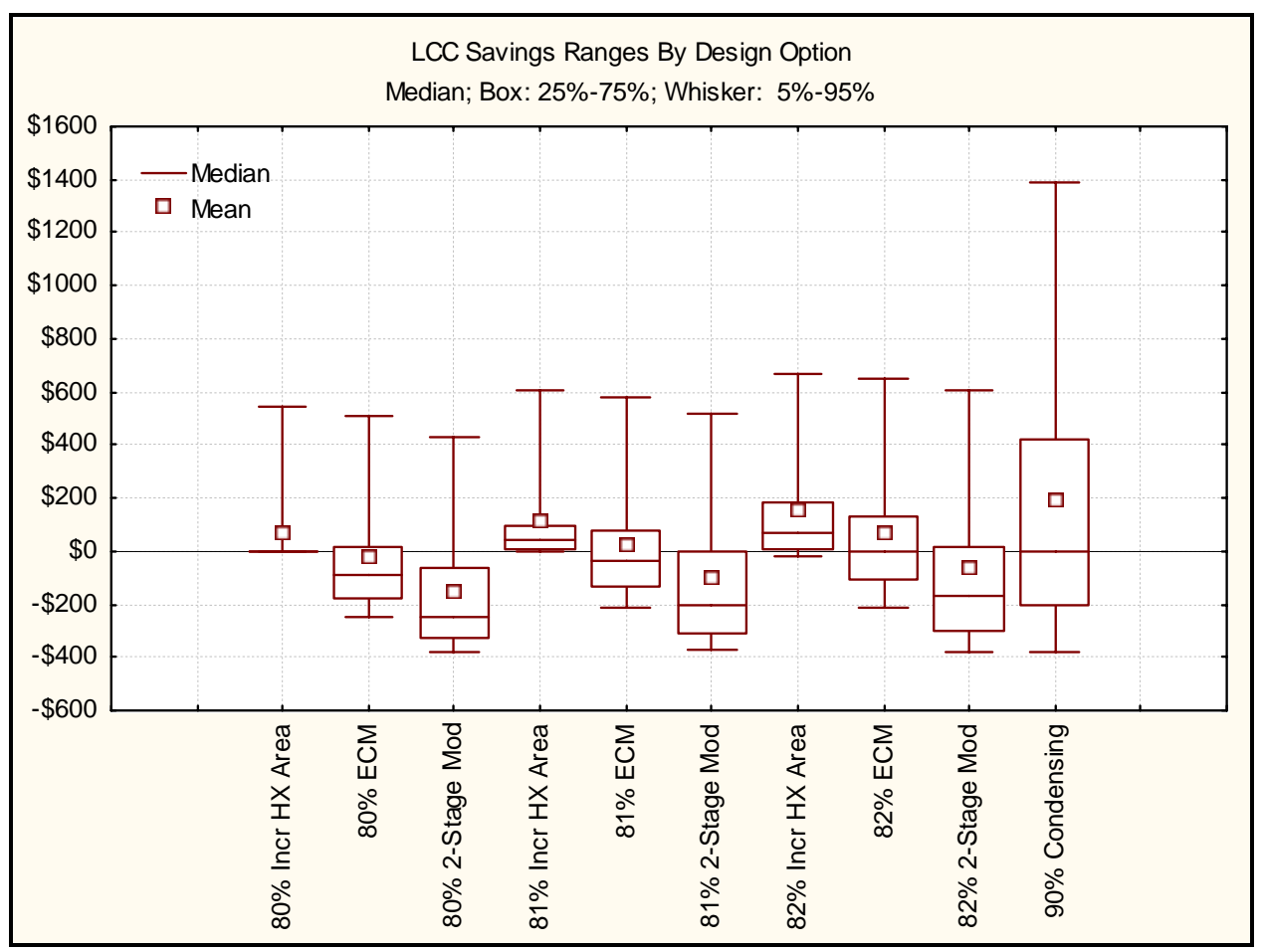

$\begin{array}{ll}\text { Figure 5.4 } & \begin{array}{l}\text { Range of LCC Savings by Design Option for } \\ \text { Manufactured-Home Gas Furnaces }\end{array}\end{array}$

For oil-fired furnaces (Table 5.4), the results show positive average LCC savings for AFUE levels from $80 \%$ through $83 \%$. The electricity-efficiency design options all have lower LCC savings than designs with baseline electricity-related features. Figure 5.5 shows the range of LCC savings by design option for oil-fired furnaces. 
Table 5.4 LCC and PBP Results for Oil-Fired Furnaces

\begin{tabular}{|c|c|c|c|c|c|c|c|}
\hline \multirow{2}{*}{$\begin{array}{c}\text { Design Option } \\
\text { (AFUE and technology description }\end{array}$} & \multicolumn{5}{|c|}{ LCC } & \multicolumn{2}{|c|}{ Payback } \\
\hline & Average & $\begin{array}{l}\text { Average } \\
\text { Savings }\end{array}$ & $\begin{array}{l}\text { Net } \\
\text { Cost }\end{array}$ & $\begin{array}{c}\text { No } \\
\text { Impact* }\end{array}$ & $\begin{array}{c}\text { Net } \\
\text { Benefit }\end{array}$ & Median & Average** \\
\hline 78\% Baseline & $\$ 16,194$ & & & & & & \\
\hline 80\% Increased HX Area & $\$ 15,900$ & $\$ 11$ & $0 \%$ & $96 \%$ & $4 \%$ & 0.2 & 0.2 \\
\hline $81 \%$ & $\$ 15,762$ & $\$ 95$ & $2 \%$ & $39 \%$ & $59 \%$ & 0.4 & 0.5 \\
\hline 81\% Atom Burner 2-stage Mod. & $\$ 15,885$ & $\$ 8$ & $42 \%$ & $30 \%$ & $28 \%$ & 11.7 & 19.4 \\
\hline 81\% Interrupted Ignition & $\$ 15,785$ & $\$ 79$ & $13 \%$ & $30 \%$ & $57 \%$ & 2.8 & 4.9 \\
\hline 81\% ImprovedSupplyFanMotor(ECM) & $\$ 15,945$ & $-\$ 33$ & $50 \%$ & $30 \%$ & $20 \%$ & 14.4 & 22.8 \\
\hline $82 \%$ & $\$ 15,625$ & $\$ 190$ & $2 \%$ & $30 \%$ & $68 \%$ & 0.3 & 0.4 \\
\hline 82\% Atom Burner 2-stage Mod. & $\$ 15,753$ & $\$ 89$ & $35 \%$ & $22 \%$ & $42 \%$ & 8.5 & 13.8 \\
\hline 82\% Interrupted Ignition & $\$ 15,648$ & $\$ 173$ & $10 \%$ & $22 \%$ & $68 \%$ & 1.7 & 3.5 \\
\hline 82\% ImprovedSupplyFanMotor(ECM) & $\$ 15,807$ & $\$ 49$ & $39 \%$ & $22 \%$ & $38 \%$ & 9.2 & 16.8 \\
\hline $83 \%$ & $\$ 15,492$ & $\$ 293$ & $3 \%$ & $22 \%$ & $75 \%$ & 0.3 & 0.4 \\
\hline 83\% Atom Burner 2-stage Mod. & $\$ 15,626$ & $\$ 178$ & $31 \%$ & $15 \%$ & $54 \%$ & 6.8 & 11.2 \\
\hline 83\% Interrupted Ignition & $\$ 15,515$ & $\$ 273$ & $10 \%$ & $15 \%$ & $75 \%$ & 1.3 & 2.9 \\
\hline 83\% ImprovedSupplyFanMotor(ECM) & $\$ 15,674$ & $\$ 138$ & $32 \%$ & $15 \%$ & $53 \%$ & 7.1 & 14.7 \\
\hline $84 \%$ & $\$ 15,967$ & $-\$ 111$ & $58 \%$ & $15 \%$ & $27 \%$ & 13.7 & 20.8 \\
\hline 84\% Atom Burner 2-stage Mod. & $\$ 16,106$ & $-\$ 240$ & $71 \%$ & $7 \%$ & $22 \%$ & 16.3 & 25.1 \\
\hline 84\% Interrupted Ignition & $\$ 15,990$ & $-\$ 133$ & $66 \%$ & $7 \%$ & $26 \%$ & 14.4 & 21.2 \\
\hline 84\% ImprovedSupplyFanMotor(ECM) & $\$ 16,148$ & $-\$ 279$ & $74 \%$ & $7 \%$ & $18 \%$ & 17.6 & 32.8 \\
\hline $85 \%$ & $\$ 15,845$ & $\$ 1$ & $49 \%$ & $7 \%$ & $44 \%$ & 10.0 & 13.8 \\
\hline 85\% Atom Burner 2-stage Mod. & $\$ 15,989$ & $-\$ 143$ & $69 \%$ & $0 \%$ & $31 \%$ & 13.7 & 20.1 \\
\hline 85\% Interrupted Ignition & $\$ 15,868$ & $-\$ 22$ & $58 \%$ & $0 \%$ & $42 \%$ & 10.8 & 14.9 \\
\hline 85\% ImprovedSupplyFanMotor(ECM) & $\$ 16,026$ & $-\$ 180$ & $72 \%$ & $0 \%$ & $28 \%$ & 14.6 & 27.3 \\
\hline
\end{tabular}

"No impact" means that the base case furnace assigned to the household has greater efficiency than the level indicated, so the household is not affected.

** From the form of the payback calculation, a very small change in operating cost can result in extremely large paybacks. These extremely large paybacks will skew the average payback. In these cases, median is probably a better indicator. 


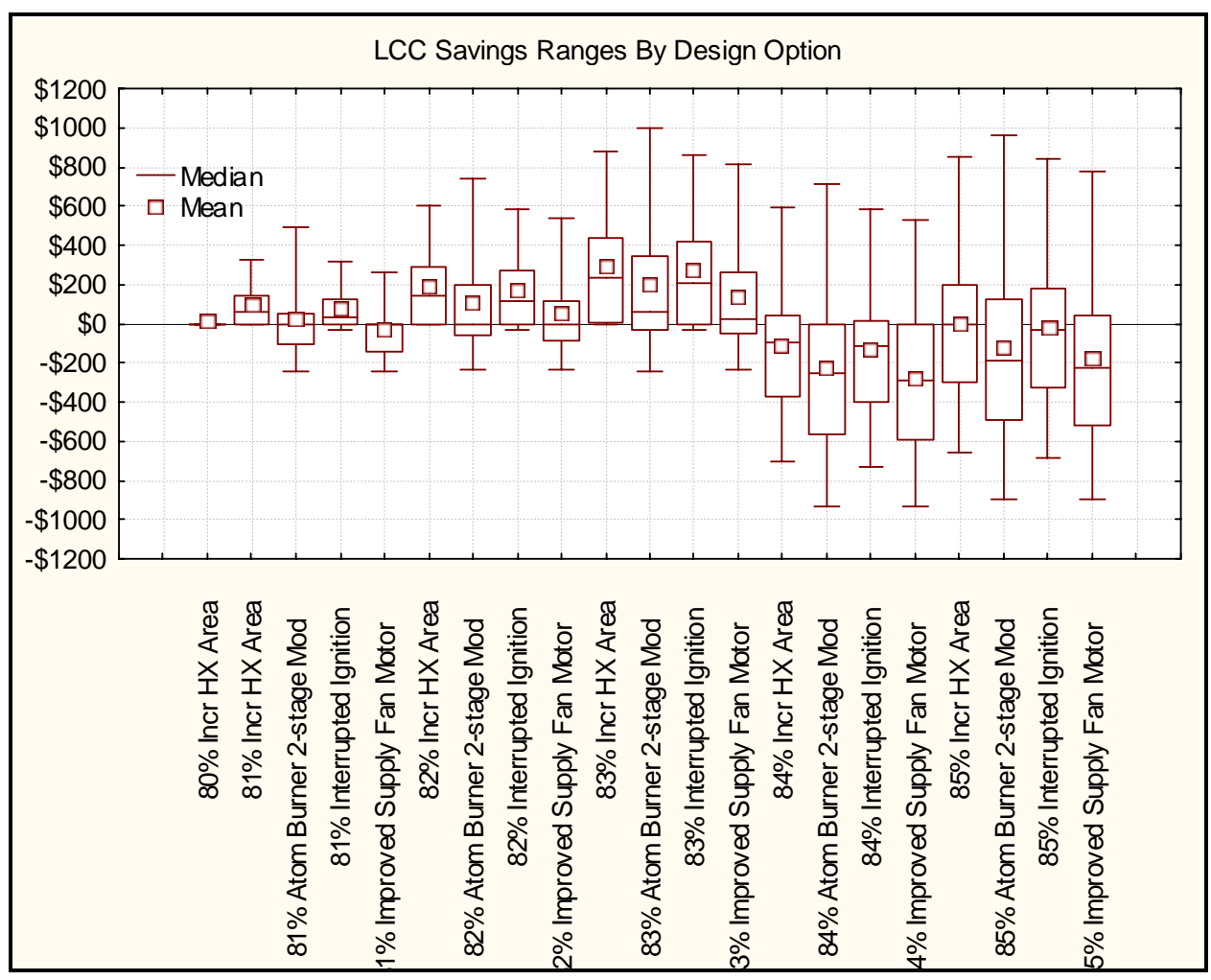

Figure 5.5 Range of LCC Savings by Design Option for Oil-Fired Furnaces 
For hot-water gas boilers (Table 5.5), the results show positive average LCC savings for the AFUE levels from 81\% through 84\%. The improved circulation pump (with ECM) has a negative effect on LCC. Figure 5.6 shows the range of LCC savings by design option for hotwater gas boilers. (Appendix D presents the LCC results for hot-water gas boilers using the alternative installation costs.)

Table 5.5 LCC and PBP Results for Hot-Water Gas Boilers

\begin{tabular}{|c|c|c|c|c|c|c|c|}
\hline \multirow{2}{*}{$\begin{array}{c}\text { Design Option } \\
\text { (AFUE and technology } \\
\text { description }\end{array}$} & \multicolumn{5}{|c|}{ LCC } & \multicolumn{2}{|c|}{ Payback } \\
\hline & $\begin{array}{c}\text { Average } \\
\text { LCC }\end{array}$ & $\begin{array}{c}\text { Average } \\
\text { Savings }\end{array}$ & Net Cost & $\begin{array}{c}\text { No } \\
\text { Impact }^{*}\end{array}$ & $\begin{array}{c}\text { Net } \\
\text { Benefit }\end{array}$ & Median & Average** \\
\hline 80\% Baseline & $\$ 10,635$ & & & & & & \\
\hline $81 \%$ & $\$ 10,371$ & $\$ 93$ & $0 \%$ & $65 \%$ & $35 \%$ & 2.1 & 2.4 \\
\hline 81\% 2-stage modulation & $\$ 10,599$ & $-\$ 36$ & $38 \%$ & $44 \%$ & $18 \%$ & 9.9 & 14.8 \\
\hline 81\% Imp Circ Pump & $\$ 10,620$ & $-\$ 48$ & $41 \%$ & $44 \%$ & $16 \%$ & 15.1 & 55.9 \\
\hline $82 \%$ & $\$ 10,314$ & $\$ 125$ & $3 \%$ & $44 \%$ & $53 \%$ & 2.5 & 3.3 \\
\hline $82 \%$ 2-stage modulation & $\$ 10,542$ & $-\$ 36$ & $48 \%$ & $30 \%$ & $22 \%$ & 9.3 & 19.6 \\
\hline 82\% Imp Circ Pump & $\$ 10,564$ & $-\$ 51$ & $51 \%$ & $30 \%$ & $19 \%$ & 19.1 & 42.9 \\
\hline $83 \%$ & $\$ 10,256$ & $\$ 166$ & $5 \%$ & $30 \%$ & $66 \%$ & 2.5 & 3.3 \\
\hline 83\% 2-stage modulation & $\$ 10,483$ & $-\$ 29$ & $59 \%$ & $15 \%$ & $27 \%$ & 9.9 & 23.3 \\
\hline 83\% Imp Circ Pump & $\$ 10,505$ & $-\$ 46$ & $61 \%$ & $15 \%$ & $24 \%$ & 17.8 & 39.6 \\
\hline $84 \%$ & $\$ 10,199$ & $\$ 215$ & $6 \%$ & $15 \%$ & $79 \%$ & 2.5 & 3.4 \\
\hline 84\% 2-stage modulation & $\$ 10,426$ & $\$ 0$ & $62 \%$ & $6 \%$ & $32 \%$ & 10.5 & 22.7 \\
\hline 84\% Imp Circ Pump & $\$ 10,448$ & $-\$ 20$ & $63 \%$ & $6 \%$ & $31 \%$ & 15.1 & 31.4 \\
\hline $88 \%$ & $\$ 10,741$ & $-\$ 294$ & $67 \%$ & $6 \%$ & $27 \%$ & 17.5 & 29.8 \\
\hline $91 \%$ & $\$ 10,823$ & $-\$ 372$ & $75 \%$ & $3 \%$ & $22 \%$ & 19.3 & 43.0 \\
\hline $99 \%$ & $\$ 11,304$ & $-\$ 853$ & $85 \%$ & $0 \%$ & $15 \%$ & 21.7 & 46.1 \\
\hline
\end{tabular}

"No impact" means that the base case furnace assigned to the household has greater efficiency than the level indicated, so the household is not affected.

** $\quad$ From the form of the payback calculation, a very small change in operating cost can result in extremely large paybacks. These extremely large paybacks will skew the average payback. In these cases, median is probably a better indicator.. 


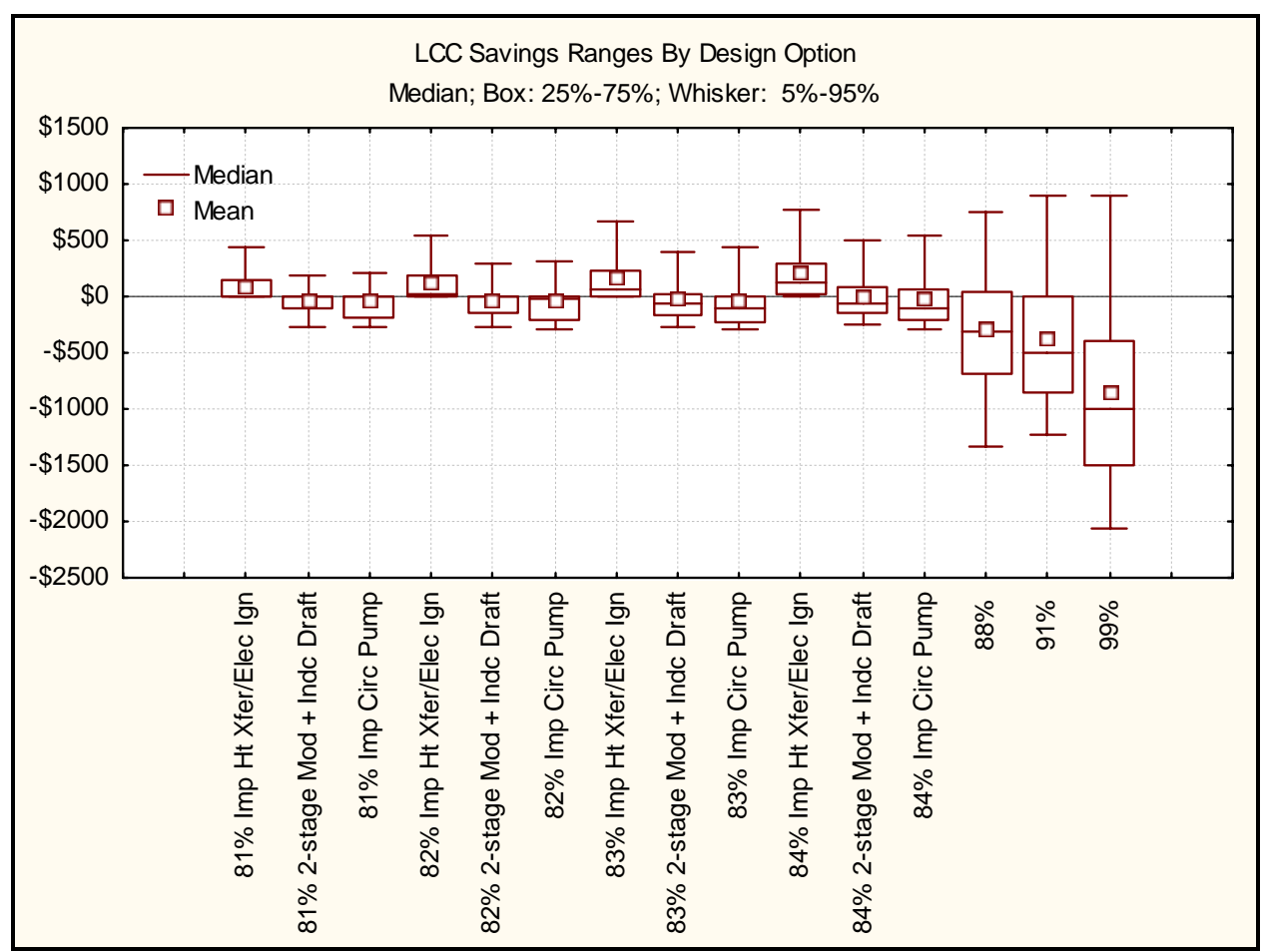

$\begin{array}{ll}\text { Figure 5.6 } & \begin{array}{l}\text { Range of LCC Savings by Design Option for Hot-Water } \\ \text { Gas Boilers }\end{array}\end{array}$

For hot-water oil-fired boilers (Table 5.6), the AFUE levels through 84\% have positive average LCC savings. Interrupted ignition shows LCC savings at the 81-83\% AFUE levels that are about the same as the designs with baseline features. The other electricity-efficiency design options have lower LCC savings than designs with baseline features. Figure 5.7 shows the range of LCC savings by design option for hot-water oil-fired boilers. 
Table 5.6 LCC and PBP Results for Hot-Water Oil-fired Boilers

\begin{tabular}{|c|c|c|c|c|c|c|c|}
\hline $\begin{array}{c}\text { Design Option } \\
\text { (AFUE and technology } \\
\text { description }\end{array}$ & Average & $\begin{array}{c}\text { Average } \\
\text { Savings }\end{array}$ & Net Cost & $\begin{array}{c}\text { No } \\
\text { Impact* }\end{array}$ & $\begin{array}{c}\text { Net } \\
\text { Benefit }\end{array}$ & Median & Average** \\
\hline 80\% Baseline & $\$ 14,890$ & & & & & & \\
\hline $81 \%$ & $\$ 14,772$ & $\$ 6$ & $0 \%$ & $95 \%$ & $5 \%$ & 0.6 & 0.8 \\
\hline 81\% Atomized Burner & $\$ 15,166$ & $-\$ 36$ & $11 \%$ & $89 \%$ & $0 \%$ & 70.4 & 104.9 \\
\hline 81\% Inter Ign & $\$ 14,776$ & $\$ 6$ & $4 \%$ & $89 \%$ & $7 \%$ & 6.0 & 9.4 \\
\hline 81\% Imp Circ Pump & $\$ 14,995$ & $-\$ 17$ & $10 \%$ & $89 \%$ & $1 \%$ & 39.5 & 64.0 \\
\hline $82 \%$ & $\$ 14,657$ & $\$ 18$ & $0 \%$ & $89 \%$ & $11 \%$ & 0.7 & 0.8 \\
\hline 82\% Atomized Burner & $\$ 15,051$ & $-\$ 45$ & $16 \%$ & $84 \%$ & $0 \%$ & 35.0 & 64.3 \\
\hline 82\% Inter Ign & $\$ 14,661$ & $\$ 18$ & $4 \%$ & $84 \%$ & $12 \%$ & 3.4 & 6.7 \\
\hline 82\% Imp Circ Pump & $\$ 14,880$ & $-\$ 17$ & $13 \%$ & $84 \%$ & $3 \%$ & 21.1 & 44.5 \\
\hline $83 \%$ & $\$ 14,545$ & $\$ 36$ & $0 \%$ & $84 \%$ & $16 \%$ & 0.7 & 0.8 \\
\hline 83\% Atomized Burner & $\$ 14,939$ & $-\$ 119$ & $37 \%$ & $61 \%$ & $2 \%$ & 23.0 & 45.0 \\
\hline 83\% Inter Ign & $\$ 14,549$ & $\$ 35$ & $16 \%$ & $61 \%$ & $23 \%$ & 7.8 & 10.1 \\
\hline 83\% Imp Circ Pump & $\$ 14,768$ & $-\$ 52$ & $33 \%$ & $61 \%$ & $6 \%$ & 52.8 & 67.8 \\
\hline $84 \%$ & $\$ 14,435$ & $\$ 79$ & $0 \%$ & $61 \%$ & $39 \%$ & 0.7 & 0.8 \\
\hline 84\% Atomized Burner & $\$ 14,830$ & $-\$ 169$ & $58 \%$ & $37 \%$ & $5 \%$ & 26.7 & 57.6 \\
\hline 84\% Inter Ign & $\$ 14,439$ & $\$ 77$ & $17 \%$ & $37 \%$ & $46 \%$ & 3.8 & 7.4 \\
\hline 84\% Imp Circ Pump & $\$ 14,659$ & $-\$ 61$ & $51 \%$ & $37 \%$ & $11 \%$ & 24.1 & 49.8 \\
\hline $86 \%$ & $\$ 14,943$ & $-\$ 234$ & $52 \%$ & $37 \%$ & $11 \%$ & 23.0 & 31.6 \\
\hline 86\% Atomized Burner & $\$ 15,338$ & $-\$ 602$ & $91 \%$ & $7 \%$ & $2 \%$ & 53.0 & 98.1 \\
\hline 86\% Inter Ign & $\$ 14,947$ & $-\$ 238$ & $73 \%$ & $7 \%$ & $20 \%$ & 17.4 & 24.9 \\
\hline 86\% Imp Circ Pump & $\$ 15,167$ & $-\$ 442$ & $88 \%$ & $7 \%$ & $5 \%$ & 41.3 & 59.3 \\
\hline $90 \%$ & $\$ 15,260$ & $-\$ 527$ & $81 \%$ & $7 \%$ & $12 \%$ & 19.6 & 23.8 \\
\hline $95 \%$ & $\$ 15,561$ & $-\$ 829$ & $88 \%$ & $0 \%$ & $12 \%$ & 19.1 & 23.0 \\
\hline
\end{tabular}

"No impact" means that the base case furnace assigned to the household has greater efficiency than the level indicated, so the household is not affected.

** From the form of the payback calculation, a very small change in operating cost can result in extremely large paybacks. These extremely large paybacks will skew the average payback. In these cases, median is probably a better indicator. 


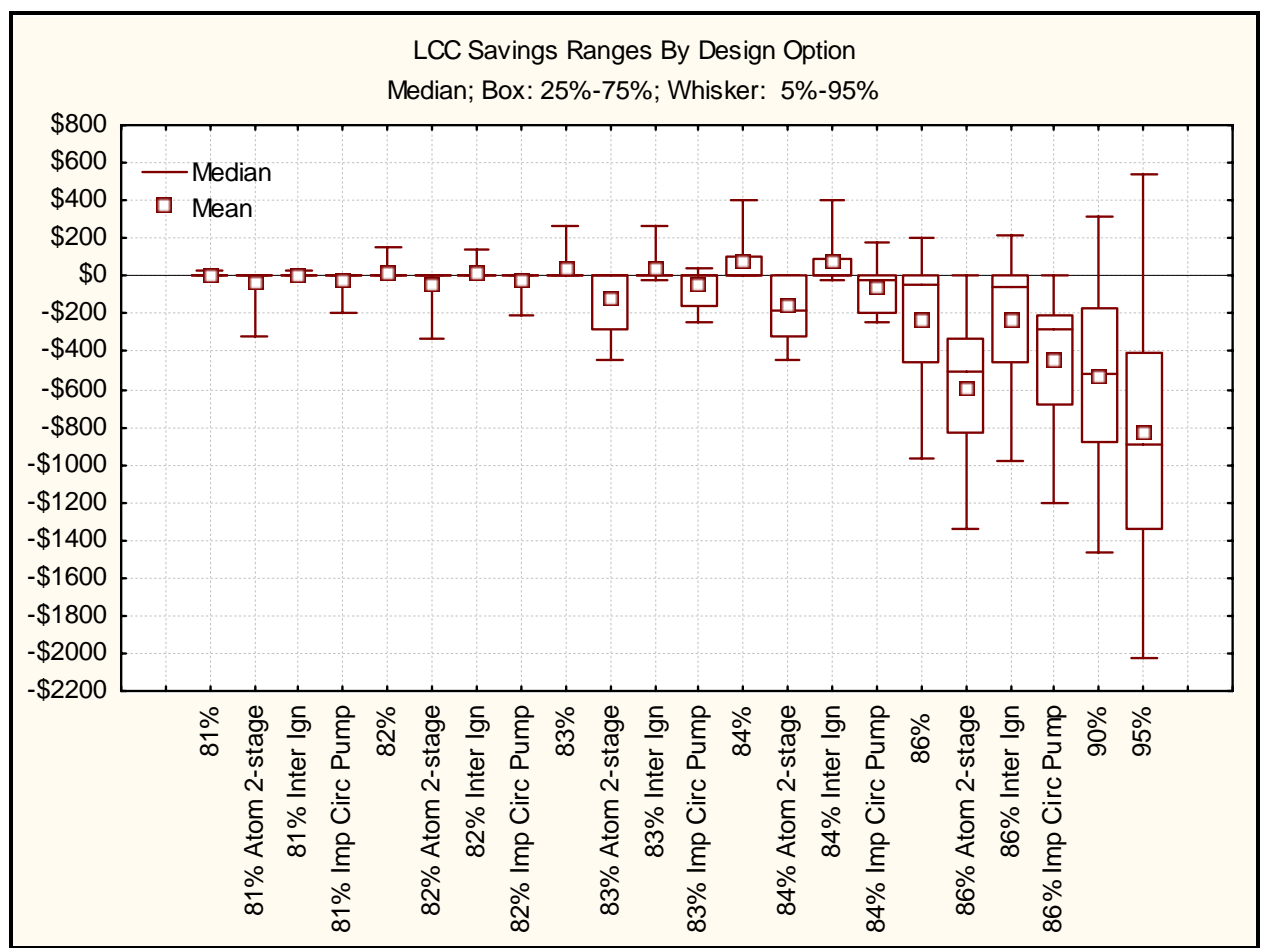

$\begin{array}{ll}\text { Figure 5.7 } & \begin{array}{l}\text { Range of LCC Savings by Design Option for Hot-Water } \\ \text { Oil-Fired Boilers }\end{array}\end{array}$

\section{CONCLUSION}

The analysis described in this report estimated the life-cycle cost (LCC) of alternative furnace and boiler designs in actual U.S. houses. We calculated the LCC for alternative equipment designs in houses that are representative of the segment of U.S. households that buy furnaces and boilers. We conducted detailed analysis of the two main components of the LCC: the first cost of buying and installing a furnace or boiler, and the annual operating costs over the lifetime of the equipment, discounted to the present. The LCC calculated in this analysis expresses the costs of installing and operating a furnace or boiler for its lifetime starting in the year 2012 — the year a new standard would take effect.

The results indicate that efficiency improvement relative to the baseline design can reduce the LCC in each of the product classes considered. For non-weatherized gas furnaces, the largest of the product classes considered, the 81\% AFUE level using single-stage shows basically no change in LCC impact, but the 81\% AFUE level using 2-stage modulation has a positive average LCC savings of $\$ 72$. The positive LCC savings for the $81 \%$ two-stage modulation design are due, in part, to it having lower energy consumption than the single-stage furnace of the same AFUE. The condensing furnace has a negative impact on average LCC, but has a positive LCC in some regions. 
For weatherized gas furnaces, the results show average LCC savings for AFUE levels through 83\%. For manufactured-home gas furnaces, the results show positive average LCC savings for the $81 \%$ and $82 \%$ AFUE levels. The $90 \%$ AFUE condensing level shows an average LCC savings of \$148, but nearly half of the households have a negative impact. For oil-fired furnaces, the results show positive average LCC savings for AFUE levels from $80 \%$ through $83 \%$.

For hot-water gas boilers and oil-fired boilers, the results show positive average LCC savings for the AFUE levels through $84 \%$

With respect to electricity efficiency design options, the improved PSC motor increases the LCC savings for gas furnaces slightly, but the ECM has a negative effect. For oil-fired furnaces and for gas and oil-fired boilers, the electricity-efficiency design options all have lower LCC savings than designs with baseline electricity-related features.

\section{Acknowledgments}

This work was supported by the Office of Building Technologies and Community Systems of the U.S. Department of Energy, under Contract No. DE-AC03-76SF00098. We acknowledge the guidance of the DOE Program manager, Mohammed Khan, and the comments of Evan Mills of LBNL. Diana Morris and Karen Olson assisted with production. 


\section{REFERENCES}

1. U.S. Department of Energy-Office of Building Technologies, Technical Support Document: Energy Efficiency Program for Consumer Products: Energy Conservation Standards for Residential Furnaces and Boilers - ANOPR Version, 2003, U.S. Department of Energy. Washington, DC. Report No. LBNL-53984.

2. Gas Appliance Manufacturers Association, "GAMA Shipment Data," DOE Docket No. EE-RM/STD-01-350. 2002.

3. Gas Appliance Manufacturers Association, Consumers' Directory of Certified Efficiency Ratings for Residential Heating and Water Heating Equipment, including First Supplement, April, 2002. Cortland, NY. Prepared by Intertek Testing Services.

4. Lekov, A., G. Stevens, J. Lutz, and S. Meyers, Cost and Energy Consumption of Energy Efficiency Design Options for Residential Furnaces and Boilers, 2003, Lawrence Berkeley National Laboratory. Berkeley, CA. Report No. LBNL-52762.

5. U.S. Department of Energy-Energy Information Administration, A Look at Residential Energy Consumption in 1997, 1999. Washington, DC. Report No. DOE/EIA-0632(97). <http://www.eia.doe.gov/pub/pdf/consumption/063297.pdf>

6. Gas Appliance Manufacturing Association, personal communication. Conference calls between GAMA and DOE. March and July, 1998.

7. U.S. Department of Commerce - Bureau of the Census, Housing Completions, 2001. 2001). <<http://www.census.gov/const/compann.pdf $>>$

8. Lutz, J. D., C. Dunham-Whitehead, and A. Lekov, Modeling Energy Consumption of Residential Furnaces and Boilers in U.S. Homes, 2003, Lawrence Berkeley National Laboratory. Berkeley, CA. Report No. LBNL-53924.

9. Chaitkin, S., J. E. McMahon, C. D. Whitehead, R. Van Buskirk, and J. Lutz, Estimating Marginal Residential Energy Prices in the Analysis of Proposed Appliance Energy Efficiency Standards. In ACEEE 2000 Summer Study on Energy Efficiency in Buildings.2000. Asilimar, CA, August 20-25: American Council for an Energy-Efficient Economy. 9: pp. 25-36. LBNL-44230.

10. The Life Expectancy/Replacement Picture. Appliance Magazine, 2001. 58(9).

11. U.S. Department of Energy-Office of Codes and Standards, Technical Support Document: Energy Efficiency Standards for Consumer Products: Room Air Conditioners, Water Heaters, Direct Heating Equipment, Mobile Home Furnaces, Kitchen Ranges and 
Ovens, Pool Heaters, Fluorescent Lamp Ballasts \& Television Sets, 1993. Washington, DC Vol. 1 of 3. Report No. DOE/EE-0009.

12. Gas Research Institute, Replacement Market for Residential Energy Service Equipment, 1990, Gas Research Institute. Report Phase A-Residential.

13. Survey of Consumer Finances, 1998. The Federal Reserve Board. (Last accessed October 8, 2002, 2002). <

http://www.federalreserve.gov/pubs/oss/oss2/98/scf98home.html.>

14. U.S. Department of Commerce - Bureau of the Census, Money Income in the United States: 2001, 2002. (Last accessed February 5, 2003, 2003).

$<$ http://www.census.gov/prod/2002pubs/p60-218.pdf>

15. Turbo Tax. 2003, Quicken. http://www.quicken.com/cms/viewers/article/taxes/53572

16. Federal Reserve Statistical Release Selected Interest Rates, H.15 Historical Data, 2000, The Federal Reserve Board.

17. Damodaran, A., Damodaran Online, 2002. Stern School of Business, New York University. (Last accessed January 16, 2002).

$<$ http://www.stern.nyu.edu/ adamodar/New_Home_Page/data.html.> 


\section{APPENDIX A: GLOSSARY OF VARIABLES AND THEIR VALUES FROM EIA'S RECS97}

We created a database using Microsoft ACCESS that contains a subset of the records and variables from EIA's 1997 Residential Energy Consumption Survey (RECS97). ${ }^{1}$ We used this RECS subset in the life-cycle cost (LCC) analysis of the residential furnace and boiler rulemaking. This appendix explains the variable name abbreviations and provides definitions of the variable values. For the entire RECS97 dataset, refer to http://www.eia.doe.gov/emeu/recs/contents.html.

In the glossary below, the variable names are listed alphabetically. A brief explanation of the variable name as it appears in the database file follows the name. Definitions of the variable's values are listed below the name.

In the ACCESS database file, we created one table and a query file for each of the six product classes. Looking at the query filter shows the algorithm used to select the records for each different product class. The variables listed appear in the LCC spreadsheets in essentially the same order as they do in the database file. 
AGECENAC AGE OF CENTRAL A/C

EQUIP

LESS THAN 2 YEARS OLD $=1$

2 TO 4 YEARS OLD $=2$

5 TO 9 YEARS OLD $=3$

10 TO 19 YEARS OLD $=4$

20 YEARS OR OLDER $=5$

AS OLD AS THE HOME (IF

VOLUNTEERED) $=6$

DON'T KNOW $=96$

NOT APPLICABLE $=99$

BTUELCOL ELEC AIR COND USE EST IN THOUSANDS OF BTU

$9999999=$ NOT APPLICABLE

BTUFOSPH FO SPACE HEAT USE EST THOUSANDS OF BTU $9999999=$ NOT APPLICABLE

BTULPSPH LPG SPACE HEAT USE EST IN KS OF BTU $9999999=$ NOT APPLICABLE

BTUNGSPH NAT GAS SPACE HEAT USE EST THOUSANDS OF BTU $9999999=$ NOT APPLICABLE
CDD65 COOLING DD TO BASE 65 1-97 TO 12-97

COOLING DEGREE DAYS ARE THE

NUMBER OF DEGREES THE AVERAGE DAILY TEMPERATURE IS ABOVE THE BASE TEMPERATURE.

TO CALCULATE DEGREE DAYS:

AVERAGE DAILY TEMPERATURE (ADT)

$=$

HIGH TEMPERATURE FOR DAY PLUS

THE LOW DIVIDED BY 2.

COOLING DEGREE DAY $(\mathrm{CDD})=\mathrm{ADT}-$ BASE TEMPERATURE. IF HDD OR CDD = OR $<0$, DEGREE DAY (DD) $=0$.

CUMULATED DEGREE DAYS ARE IN

WHOLE DAYS.

COOLTYPE TYPE OF AC EQUIP

CENTRAL SYSTEM $=1$

INDIVIDUAL UNITS $=2$

BOTH CENTRAL AND UNITS $=3$

DON'T KNOW $=6$

REFUSED $=7$

NO ANSWER $=8$

NOT APPLICABLE $=9$

DIVISION CENSUS DIVISION

NEW ENGLAND $=1$

MIDDLE ATLANTIC $=2$

EAST NORTH CENTRAL $=3$

WEST NORTH CENTRAL $=4$

SOUTH ATLANTIC $=5$

EAST SOUTH CENTRAL $=6$

WEST SOUTH CENTRAL $=7$

MOUNTAIN $=8$

PACIFIC $=9$

DOEID DOE 4-DIGIT IDENTIFICATION NUMBER

DOLLARFO ESTIMATED COST OF FO IN

DOLLARS $99999=$ NOT APPLICABLE 
DOLLARLP ESTIMATED COST OF LPG IN DOLLARS 99999 = NOT APPLICABLE

ELECRATE LOCAL ELECTRIC RATE FOR 1000KWH AVERAGE RESIDENTIAL RATE, IN CENTS PER KILOWATT, OF ELECTRICITY COMPUTED FROM 1997 TYPICAL ELECTRIC BILL DATA. WHERE DATA WERE NOT AVAILABLE, A RATE WAS IMPUTED FROM KNOWN RATES IN AREAS NEAR THE HOUSEHOLD WITH MISSING INFORMATION. DATA INCLUDES AN ERROR TERM.

FIELD CONTAINS ONE IMPLIED DECIMAL PLACE.

$999=$ NOT APPLICABLE

EQUIPAGE AGE OF MAIN HEATING EQUIP

LESS THAN 2 YEARS OLD $=1$

2 TO 4 YEARS OLD $=2$

5 TO 9 YEARS OLD $=3$

10 TO 19 YEARS OLD $=4$

20 YEARS OR OLDER $=5$

AS OLD AS THE HOME (IF

VOLUNTEERED) $=6$

DON'T KNOW $=96$

NOT APPLICABLE $=99$
EQUIPM MAIN HOME HEATING

EQUIPMENT

STEAM $=2$

CENTRAL WARM-AIR FURNACE WITH

DUCTS $=3$

HEAT PUMP $=4$

BUILT-IN ELECTRIC UNITS IN THE

WALLS, ETC. $=5$

BUILT-IN FLOOR $=6$

ROOM HEATER BURNING GAS, OIL, OR

KEROSENE $=7$

HEATING STOVE $=8$

FIREPLACE $=9$

PORTABLE ELECTRIC HEATERS $=10$

PORTABLE KEROSENE HEATERS $=11$

COOKING STOVE (USED TO HEAT

HOME) $=12$

EQUIPMENT NOT LISTED $=21$

NOT APPLICABLE $=99$

FUELHEAT MAIN HOME HEATING

FUEL CON 3

NATURAL GAS FROM UNDERGROUND

PIPES $=1$

BOTTLED GAS (LPG OR PROPANE) $=2$

FUEL OIL $=3$

KEROSENE $=4$

ELECTRICITY $=5$

WOOD $=7$

SOLAR $=8$

DISTRICT STEAM $=9$

SOME OTHER FUEL $=21$

DON'T HEAT HOME $=00$

GALLONFO EST GALLONS OF FUEL OIL BOUGHT 999999 = NOT APPLICABLE

GALLONLP EST GALLONS OF LPG BOUGHT OBS 6

$999999=$ NOT APPLICABLE

HDD65 HEATING DD TO BASE 65 1-97

TO 12-97 
HEATING DEGREE DAYS ARE THE NUMBER OF DEGREES THE AVERAGE DAILY TEMPERATURE IS BELOW THE BASE TEMPERATURE.

TO CALCULATE DEGREE DAYS: AVERAGE DAILY TEMPERATURE $($ ADT $)=$ HIGH TEMPERATURE FOR DAY PLUS THE LOW DIVIDED BY 2.

HEATING DEGREE DAY (HDD) = BASE TEMPERATURE (E.G. 65 DEGREES) - ADT IF HDD $=$ OR $<0$, DEGREE DAY (DD) $=0$. CUMULATED DEGREE DAYS ARE IN WHOLE DAYS.

LRG+DIV LARGE STATE AND CENSUS DIVISION DESIGNATIONS

NEW ENGLAND $=1$

MIDDLE ATLANTIC LESS NY $=2$

EAST NORTH CENTRAL $=3$

WEST NORTH CENTRAL $=4$

SOUTH ATLANTIC LESS FL $=5$

EAST SOUTH CENTRAL $=6$

WEST SOUTH CENTRAL LESS TX $=7$

MOUNTAIN $=8$

PACIFIC LESS CA $=9$

NEW YORK STATE $=10$

CALIFORNIA $=11$

TEXAS $=12$

FLORIDA $=13$

LRGSTATE LARGE STATE DESIGNATION NEW YORK STATE $=1$

CALIFORNIA $=2$

TEXAS $=3$

FLORIDA $=4$

NHSLDMEM NUMBER OF HOUSEHOLD MEMBERS

DON'T KNOW $=96$

REFUSED $=97$

NO ANSWER $=98$

NOT APPLICABLE $=99$

NWEIGHT THE FINAL WEIGHT

THE FINAL WEIGHT (REFLECTING THE PRODUCT OF THE PRE-SECOND STAGE WEIGHT AND THREE ADJUSTMENTS)
POOR100 BELOW 100 PERCENT OF

POVERTY

POVERTY DEFINED AS 100 PERCENT OF POVERTY LINE. POVERTY LINE VARIES WITH HOUSEHOLD SIZE (1-9), AGE AND HOUSEHOLD INCOME. FOR HOUSEHOLD SIZE OF :

1 - AGE 65 AND OVER, LESS THAN \$ 7,525

1 - AGE 64 AND UNDER, LESS THAN \$ 8,163

2 - AGE 65 AND OVER, LESS THAN \$ 9,491

2 - AGE 64 AND UNDER, LESS THAN \$ 10,507

3 - LESS THAN $\$ 12,516$

4 - LESS THAN $\$ 16,036$

5 - LESS THAN $\$ 18,952$

6 - LESS THAN \$21,389

7 - LESS THAN $\$ 24,268$

8 - LESS THAN $\$ 27,091$

9 OR MORE - LESS THAN \$31,971

POOR $100 \%=1$

NONPOOR $=0$

NO ANSWER $=8$

REGIONC CENSUS REGION

NORTHEAST $=1$

MIDWEST $=2$

SOUTH $=3$

$\mathrm{WEST}=4$

SQFTREG MODEL-BASED EST. OF HEATED SQ FT

$99999=$ NOT APPLICABLE

TYPEHUQ RESP REPORTED TYPE OF HOME MOBILE HOME = 1

SINGLE-FAMILY DETACHED $=2$

SINGLE-FAMILY ATTACHED $=3$

APARTMENT BUILDING WITH 2-4 UNITS $=4$ APARTMENT BUILDING WITH 5 OR MORE UNITS $=5$ 
UGASRATE LOCAL NATURAL GAS RATE FOR MCF AVERAGE RESIDENTIAL RATE FOR MCF OF NATURAL GAS COMPUTED FROM 1997 TYPICAL NATURAL GAS BILL DATA. WHERE DATA WERE NOT AVAILABLE, A RATE WAS IMPUTED FROM KNOWN RATES IN AREAS NEAR THE HOUSEHOLD WITH MISSING INFORMATION. DATA INCLUDES AN ERROR TERM. HOUSEHOLDS THAT DO NOT USE NATURAL GAS ARE CODED 9999 FOR NOT APPLICABLE. FIELD CONTAINS TWO IMPLIED DECIMAL PLACES.

YEARMADE YEAR HOME BUILT BEFORE $1940=1$

$1940-49=2$

$1950-59=3$

$1960-69=4$

$1970-76=5$

$1977-79=6$

$1980-86=7$

$1987-89=8$

$1990=9$

$1991=10$

$1992=11$

$1993=12$

$1994=13$

$1995=14$

$1996=15$

$1997=16$

NOT APPLICABLE $=99$

YEARS1 INFANTS IN HH UNDER 1

NOT APPLICABLE $=99$

YEARS2 CHILDREN IN HH 1-12

NOT APPLICABLE $=99$

YEARS3 ADULTS IN HH OVER 65

DON'T KNOW = 96

REFUSED $=97$

NO ANSWER $=98$

NOT APPLICABLE $=99$
YEARS4 ADULTS IN HH OVER 75

NOT APPLICABLE $=99$ 


\section{REFERENCE}

1. U.S. Department of Energy - Energy Information Administration, Residential Energy Consumption Survey: Household Energy Consumption and Expenditures 1997, 1999. Washington, DC. Report No. DOE/EIA-0321(97).

<http://www.eia.doe.gov/emeu/recs/recs97/publicusefiles.html> 


\section{APPENDIX B: DISTRIBUTION OF DISCOUNT RATES}

\section{B.1 DISTRIBUTION OF DISCOUNT RATES FOR NEW INSTALLATION FURNACES}

Figure B.1.1 shows the distribution of nominal interest rates for new home mortgages. ${ }^{1}$ The real discount rate equals the nominal rate after deducting taxes (28\%) and 1998 inflation $(1.5 \%) .^{2}$ The median U.S household income in 2000 was \$43,162. The marginal income tax of heads of households with this income is $27.5 \%$. We rounded the $27.5 \%$ figure to $28 \%$ for this analysis.

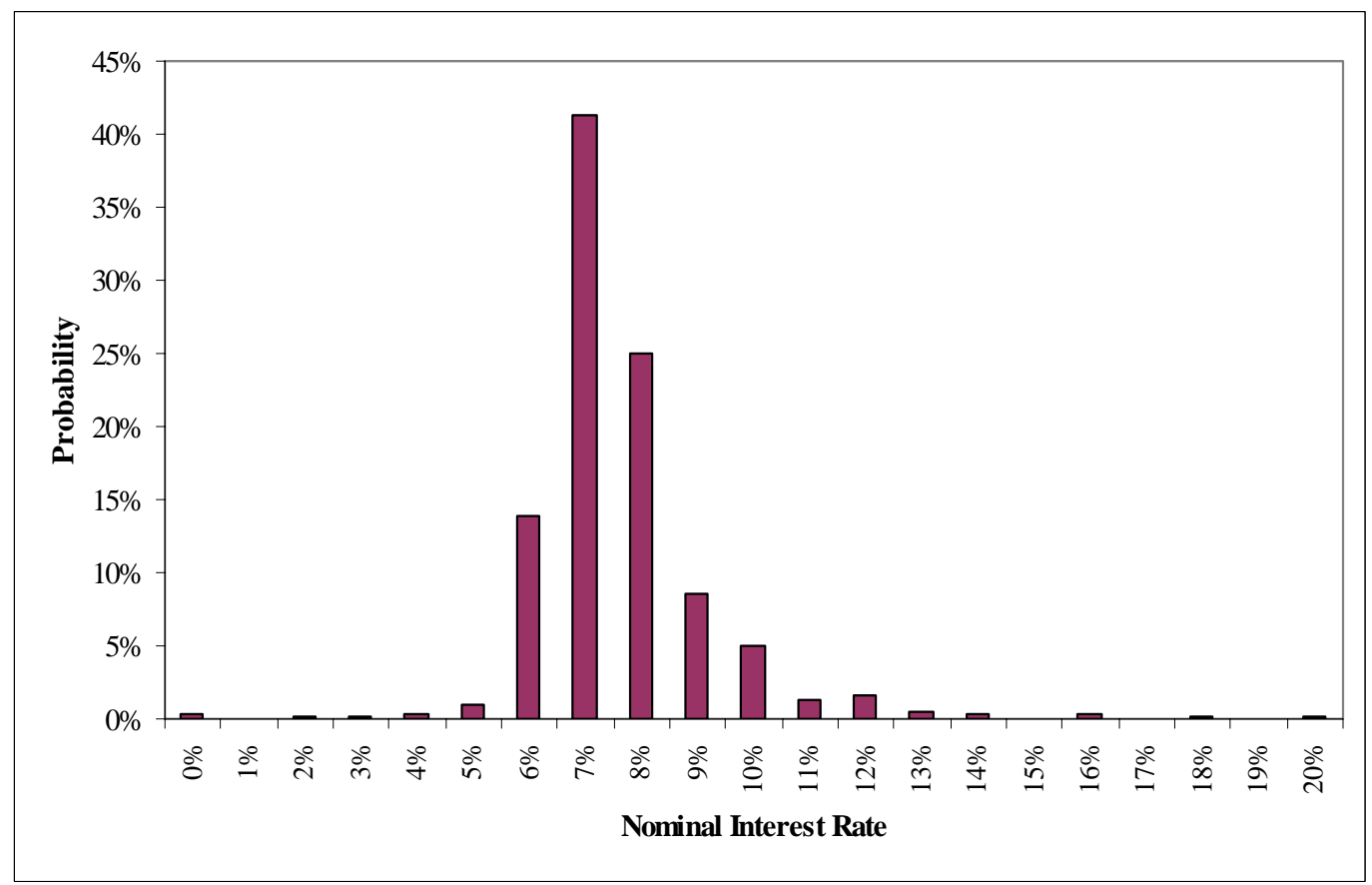

Figure B.1.1 Distribution of New Home Mortgage Nominal Interest Rates

\section{B.2 DISTRIBUTION OF DISCOUNT RATES FOR REPLACEMENT FURNACES}

Figures B.2.1 through B.2.6 show the distribution of nominal interest rates for types of debt and equity used to finance replacement furnaces. These include distributions for second mortgages and credit cards, ${ }^{1}$ certificates of deposit, ${ }^{3}$ savings bonds, ${ }^{4}$ and corporate bonds, ${ }^{5}$ stocks, ${ }^{6}$ and mutual funds. The real discount rate equals the nominal rate after deducting taxes (28\%) from mortgages and 1998 inflation (1.5\%) from the other finance methods.

We defined certificates of deposit (CDs) returns based on returns to six-month, secondary market CDs (1977-1999). We defined returns to savings bonds as the returns to one-year 
Treasury Bills (1977-1999). We defined returns to corporate bonds as the returns to Moody's AAA Corporate Bonds (1977-1999). We derived the mutual fund interest rate data according to the average return to stocks, treasury bonds, and savings bonds.

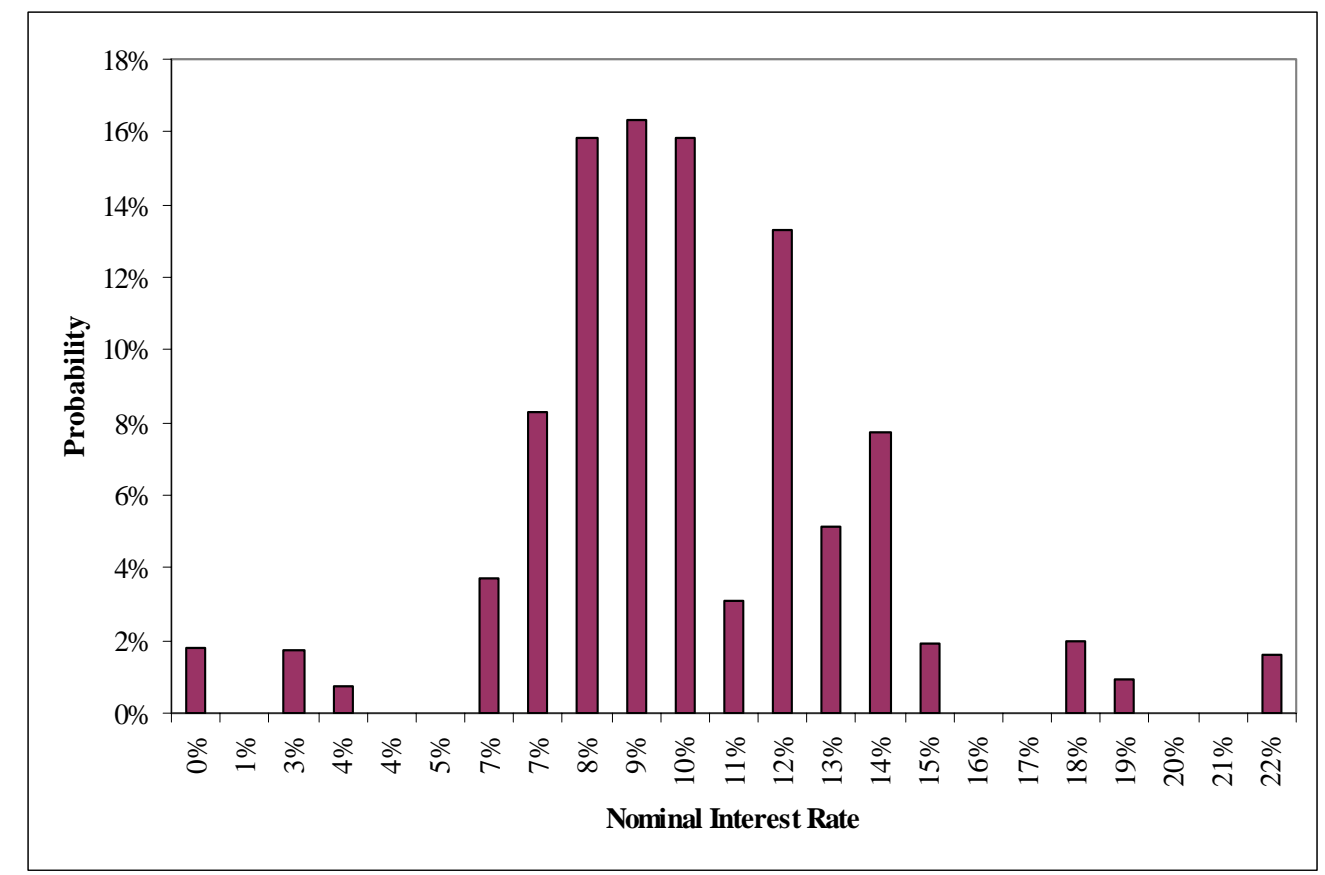

Figure B.2.1 Distribution of Second Mortgage Nominal Interest Rates 


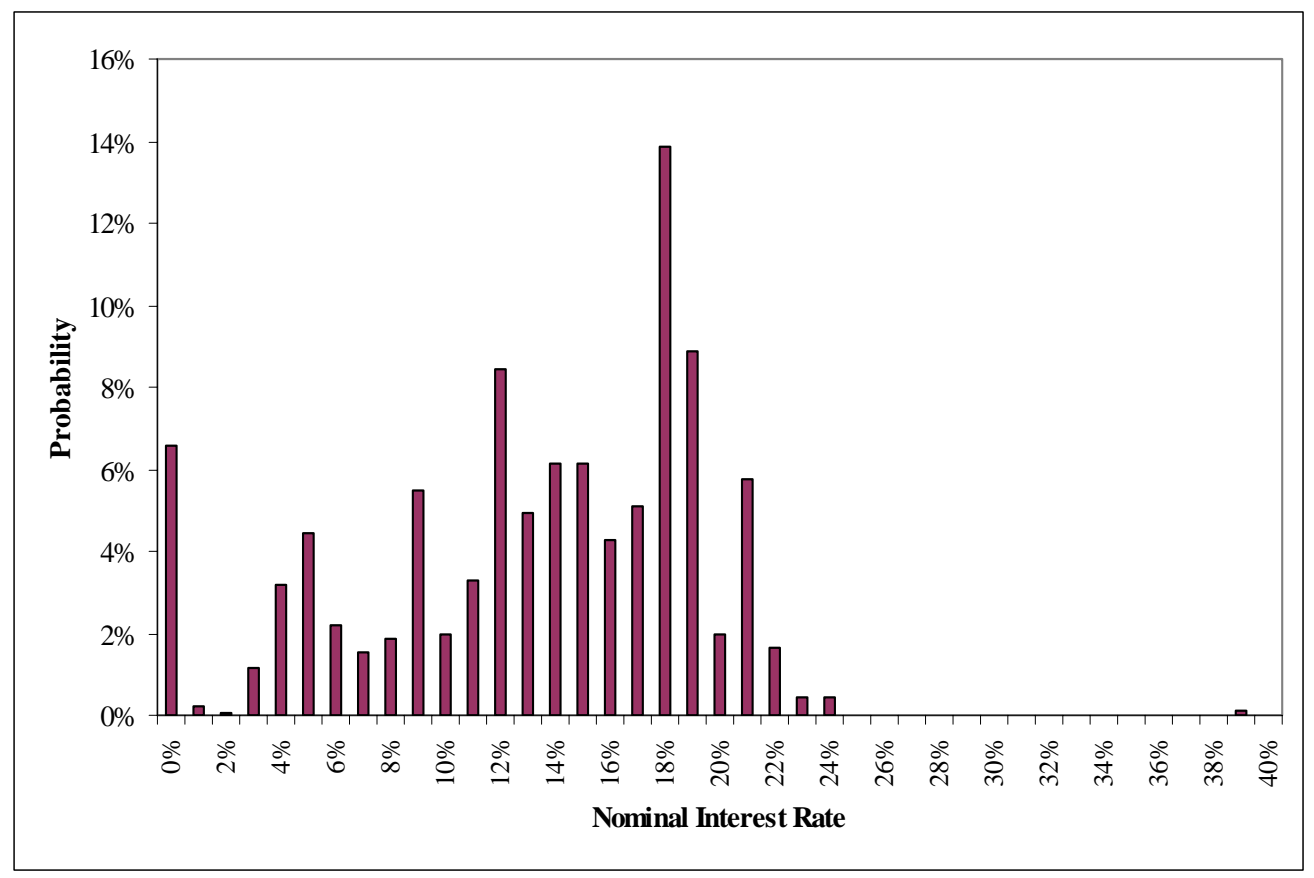

Figure B.2.2 Distribution of Credit Card Nominal Interest Rates

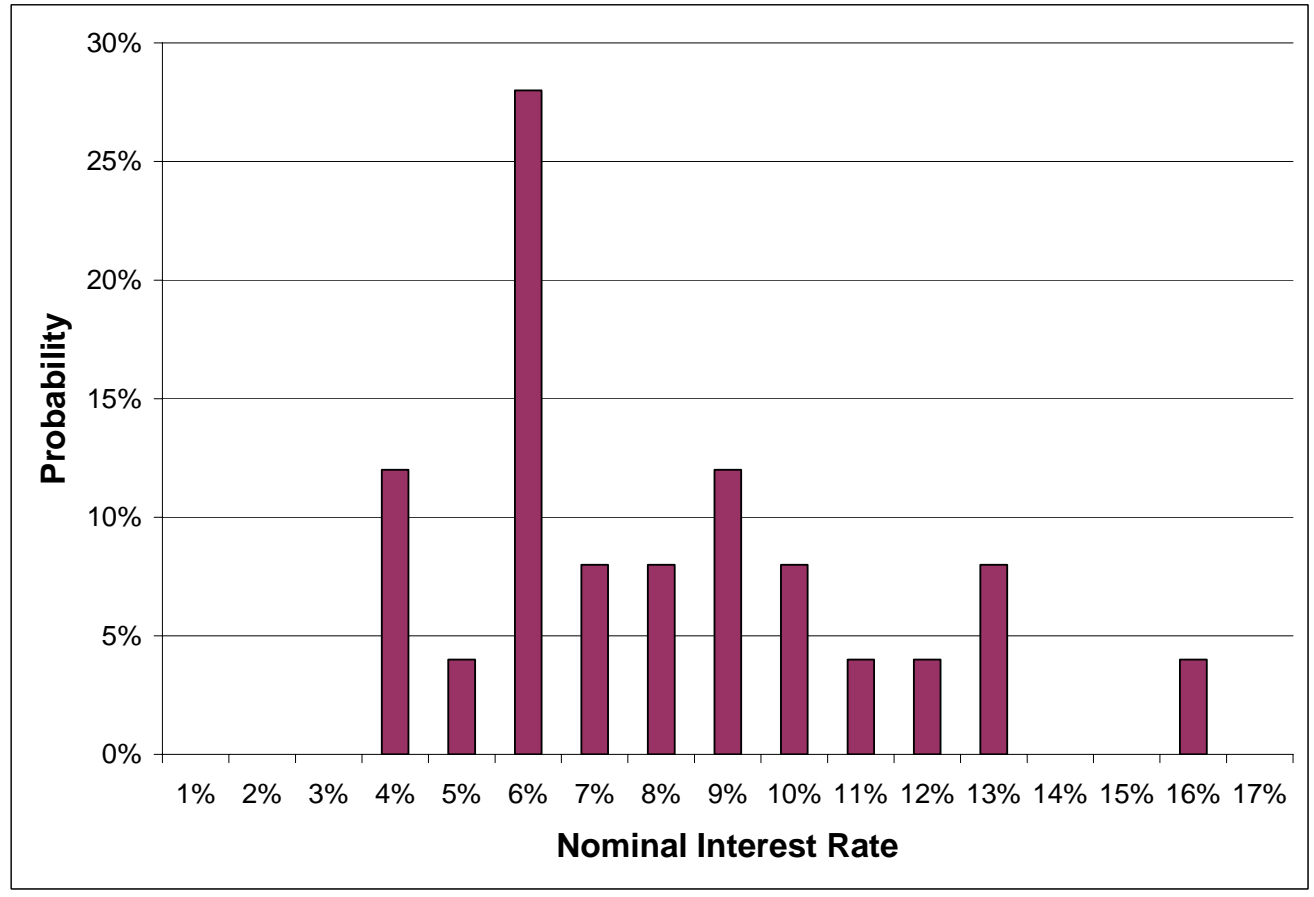

Figure B.2.3 Distribution of CD's Nominal Interest Rates 


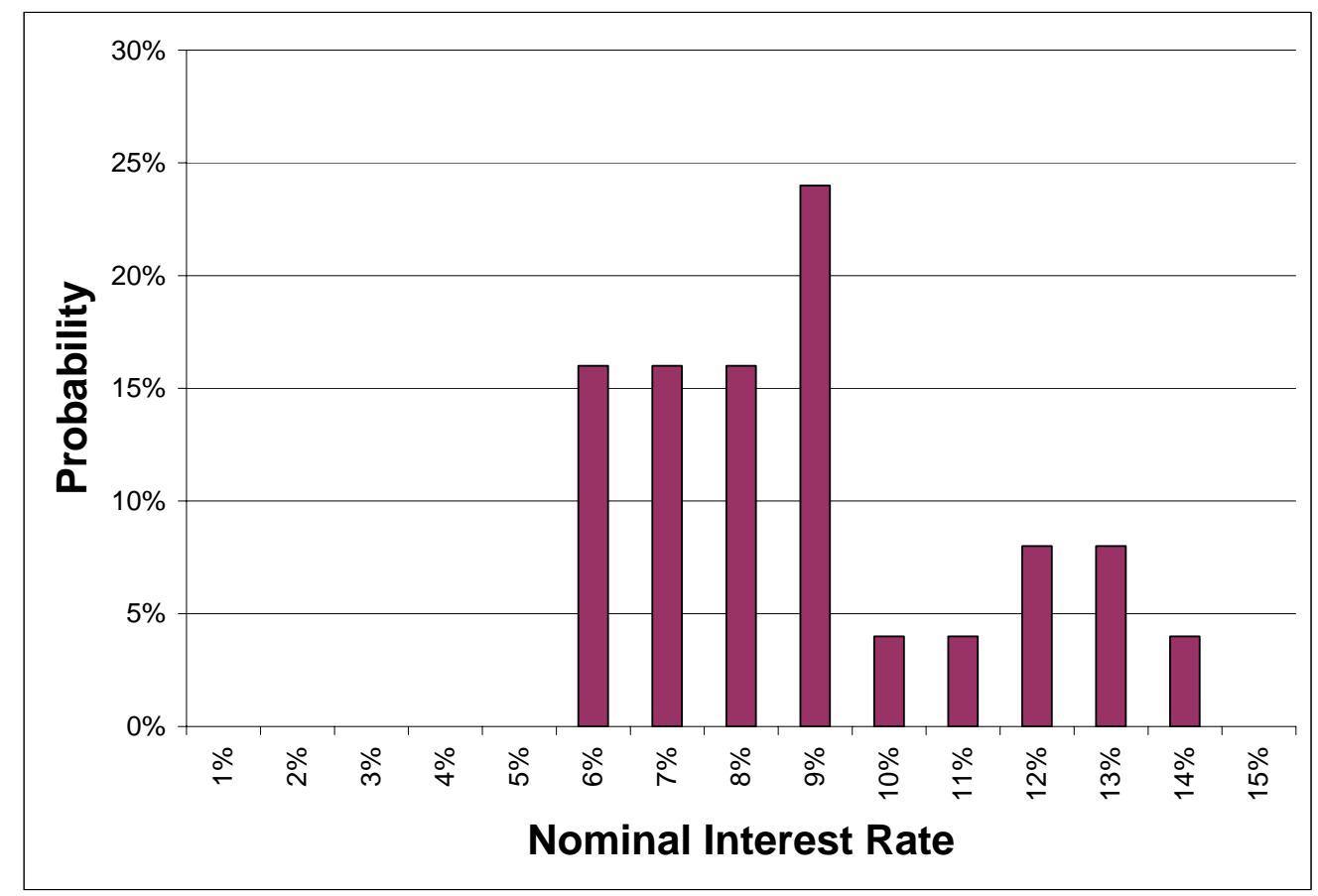

Figure B.2.4 Distribution of T-Bill Nominal Interest Rates

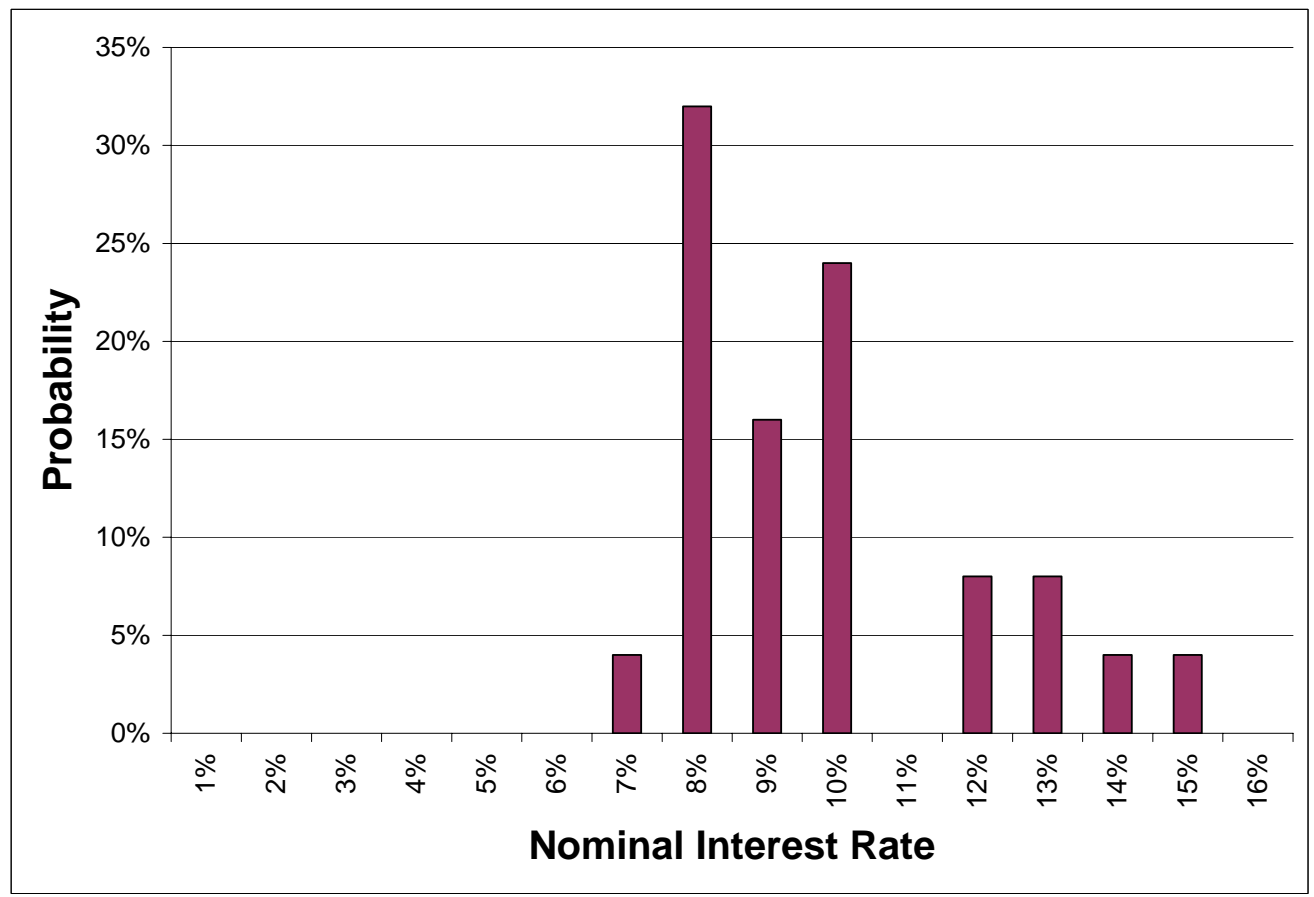

Figure B.2.5 Distribution of Corporate Bond Nominal Interest Rates 


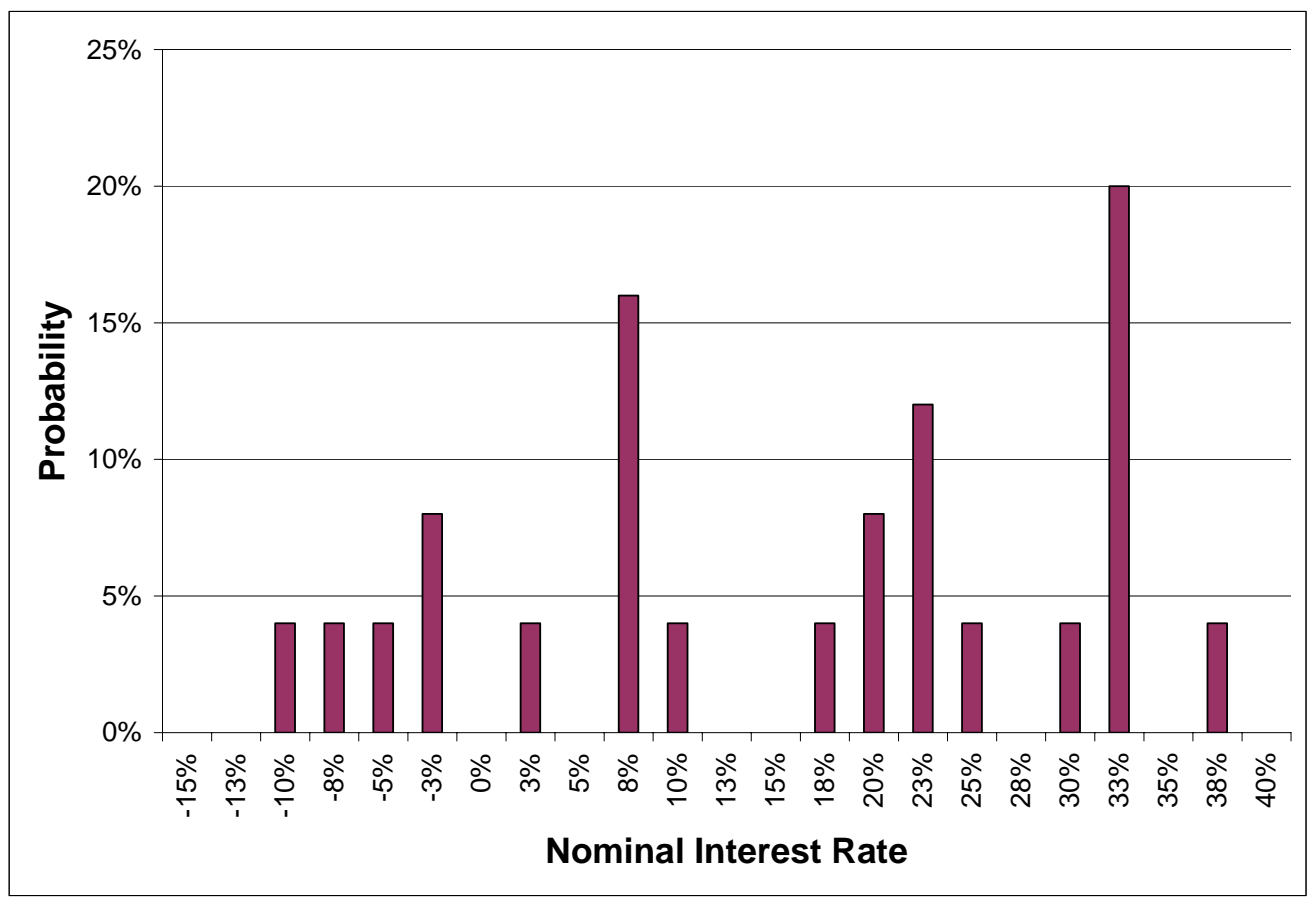

Figure B.2.6 Distribution of S\&P 500 Nominal Return Rates 


\section{REFERENCE}

1. Survey of Consumer Finances, 1998. The Federal Reserve Board. (Last accessed October 8, 2002, 2002). <

http://www.federalreserve.gov/pubs/oss/oss2/98/scf98home.html.>

2. Council of Economic Advisors, U. S. G. P. O., 1998 Inflation: Council of Economic Advisors, Economic Report of the President, 1998. 2003).

<http://w3.access.gpo.gov/usbudget/fy2003/erp.html>

3. The Federal Reserve Board, Federal Reserve Statistical Release, Selected Interest Rates, H.15 Historical Data, CDs (secondary market), 6-month, 2000. (Last accessed March 15, 2001). <http://www.bog.frb.fed.us/releases/H15/data.htm>

4. U.S. Federal Reserve Statistical Release, 2002. November, 2002).

$<$ http://www.federalreserve.gov/releases/h15/data/a/tcm30y.txt>

5. The Federal Reserve Board, Federal Reserve Statistical Release, Selected Interest Rates, H.15 Historical Data, Corporate bonds, Moody's seasoned, AAA, 2000. (Last accessed March 15, 2001). <http://www.bog.frb.fed.us/releases/H15/data.htm>

6. Damodaran Online Data Page, Historical Returns on Stocks, Bonds and Bills-United States, Damodaran. (Last accessed October 9, 2002),

$<$ http://pages.stern.nyu.edu/ adamodar/> 


\section{APPENDIX C: LCC AND PAYBACK PERIOD RESULTS USING ALTERNATIVE ENERGY PRICE SCENARIOS}

\section{TABLE OF CONTENTS}

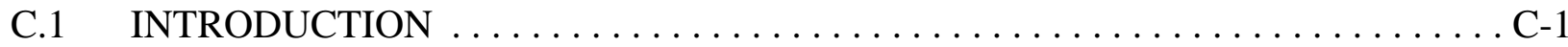

C.2 LCC AND PBP RESULTS USING AEO 2003 HIGH GROWTH

PRICE SCENARIO ...................................

C.3 LCC AND PBP RESULTS USING AEO 2003 LOW GROWTH

PRICE SCENARIO ................................... -16

\section{LIST OF TABLES}

Table C.2.1 LCC and PBP Results for Non-Weatherized Gas Furnaces (High Growth) ... C-3

Table C.2.2 LCC and PBP Results for Weatherized Gas Furnaces (High Growth) ....... C-6

Table C.2.3 LCC and PBP Results for Manufactured Home Furnaces (High Growth) . . . . C-8

Table C.2.4 LCC and PBP Results for Oil Furnaces (High Growth) $\ldots \ldots \ldots \ldots \ldots$ C-10

Table C.2.5 LCC and PBP Results for Gas Boilers (High Growth) $\ldots \ldots \ldots \ldots \ldots \ldots$ C-12

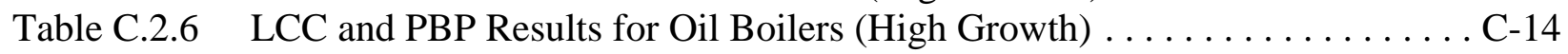

Table C.3.1 LCC and PBP Results for Non-Weatherized Gas Furnaces (Low Growth) . . C-16

Table C.3.2 LCC and PBP for Weatherized Furnaces (Low Growth) $\ldots \ldots \ldots \ldots \ldots$ C-19

Table C.3.3 LCC and PBP Results for Manufactured Home Furnaces (Low Growth) . . . C-21

Table C.3.4 LCC and PBP Results for Oil Furnaces (Low Growth) . . . . . . . . . . . C-23

Table C.3.5 LCC and PBP Results for Oil Boilers (Low Growth) $\ldots \ldots \ldots \ldots \ldots \ldots$ C-25

Table C.3.6 LCC and PBP Results for Gas Boilers (Low Growth) $\ldots \ldots \ldots \ldots \ldots \ldots$ C-27

\section{LIST OF FIGURES}

Figure C.1.1 Residential Natural Gas Price Forecast (AEO 2003) ................ C-1

Figure C.1.2 Residential Electricity Price Forecast (AEO 2003) . . . . . . . . . . . . . . C-2

Figure C.1.3 Residential Oil Fuel Price Forecast (AEO 2003) . . . . . . . . . . . . . . C-2

Figure C.2.1 National LCC Savings Results for Non-Weatherized Gas Furnaces

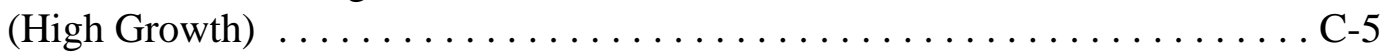

Figure C.2.2 National LCC Savings Results for Weatherized Furnaces (High Growth) . . . C-7 Figure C.2.3 National LCC Savings Results for Manufactured Home Furnaces

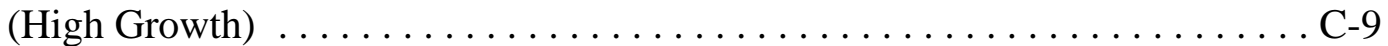

Figure C.2.4 National LCC Savings Results for Oil Furnaces (High Growth) $\ldots \ldots \ldots \ldots$. .

Figure C.2.5 National LCC Savings Results for Gas Boilers (High Growth) $\ldots \ldots \ldots \ldots$ C-13

Figure C.2.6 National LCC Savings Results for Oil Boilers (High Growth) . . . . . . . . C C-15

Figure C.3.1 National LCC Savings Results for Non-Weatherized Gas Furnaces

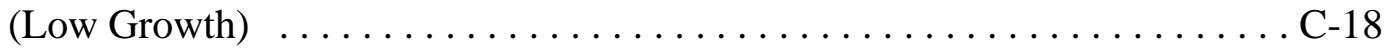


Figure C.3.2 National LCC Savings Results for Weatherized Furnaces (Low Growth) ... C-20

Figure C.3.3 National LCC Savings Results for Manufactured Home Furnaces

(Low Growth) . . . . . . . . . . . . . . . . . . . . . . . . . . . . . . . . C-22

Figure C.3.4 National LCC Savings Results for Oil Furnaces (Low Growth) . . . . . . . . . C-24

Figure C.3.5 National LCC Savings Result for Oil Boilers (Low Growth) . . . . . . . . . . C-26

Figure C.3.6 National LCC Savings Results for Gas Boilers (Low Growth) . . . . . . . . . . C-28 


\section{APPENDIX C: LCC AND PAYBACK PERIOD RESULTS USING ALTERNATIVE ENERGY PRICE SCENARIOS}

\section{C.1 INTRODUCTION}

This appendix presents LCC and payback results using alternative energy price scenarios from EIA's AEO 2003. ${ }^{1}$

Figures C.1.1, C.1.2 and C.1.3 show the price forecasts from AEO 2003 for natural gas, oil, and electricity for the three economic growth cases considered by EIA. For natural gas, the price in the High Economic Growth case is considerably higher than in the Reference case in 2012. The decline in 2018-2020 is due to the fact that initial gas flows from the Alaskan pipeline occur earlier in the High Economic Growth case than in the Reference case. The price in this case rises much faster than in the Reference case after 2020 due to higher economic growth causing greater demand for gas. ${ }^{\text {a }}$

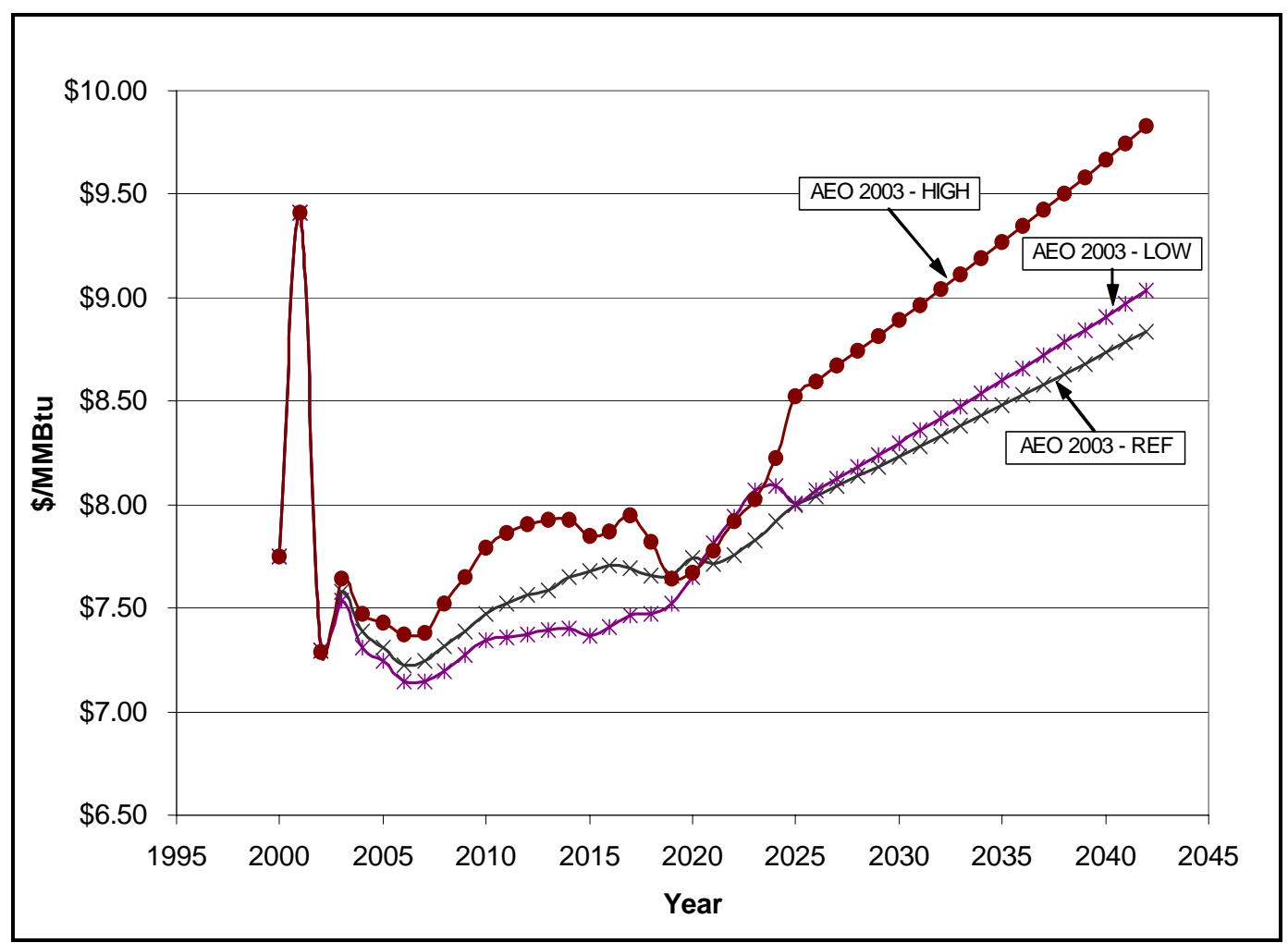

Figure C.1.1 Residential Natural Gas Price Forecast (AEO 2003)

\footnotetext{
a After 2025, the price in the Low Economic Growth case is higher than in the Reference case. This results from our use of the average annual growth rate in the $2010-2025$ period to project post-2025 prices. In the Low case, Alaskan gas flows occur later in time, so the price of gas rises significantly in the 2015-2025 period despite the lower economic growth in this case.
} 


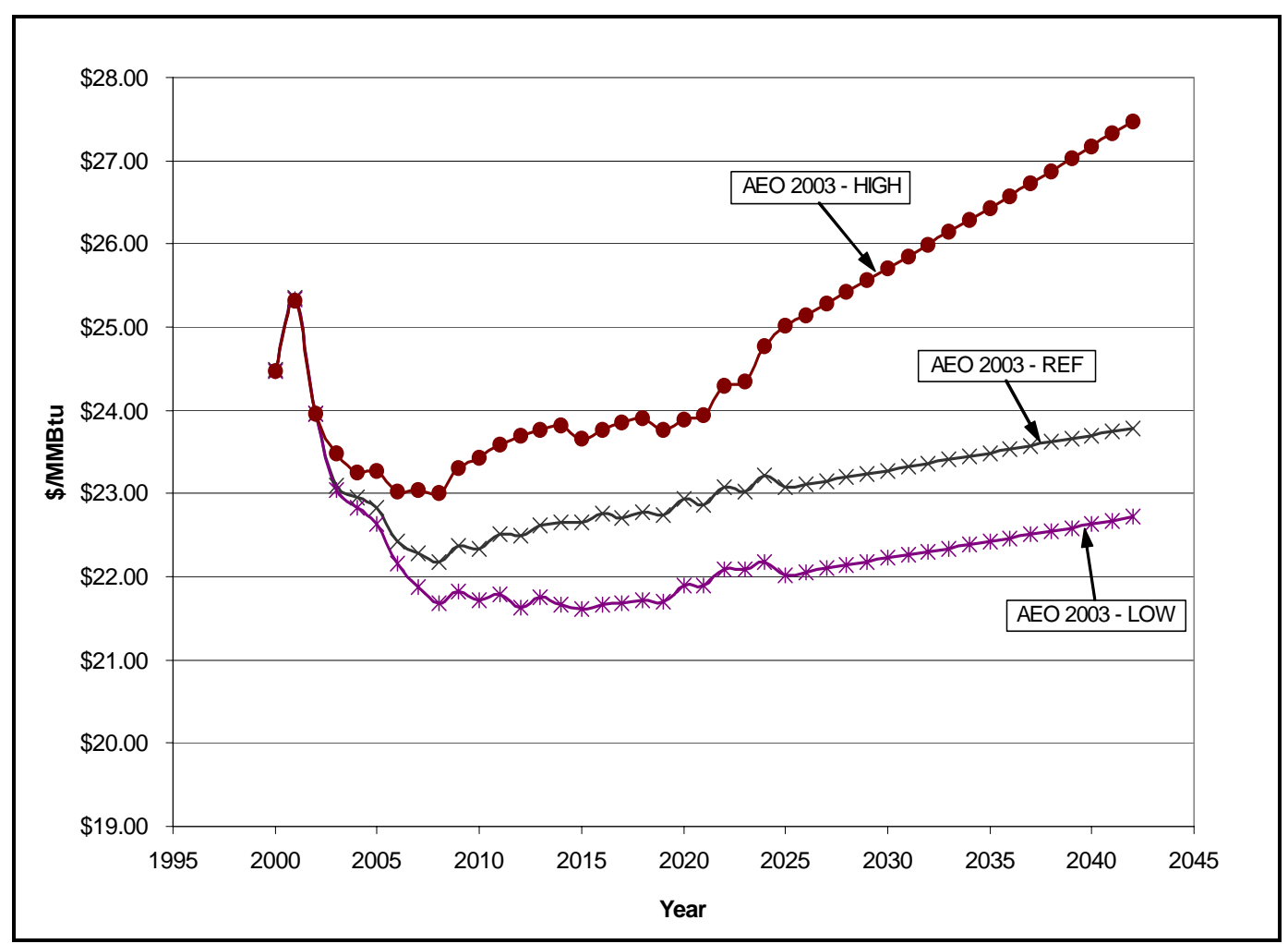

Figure C.1.2 Residential Electricity Price Forecast (AEO 2003)

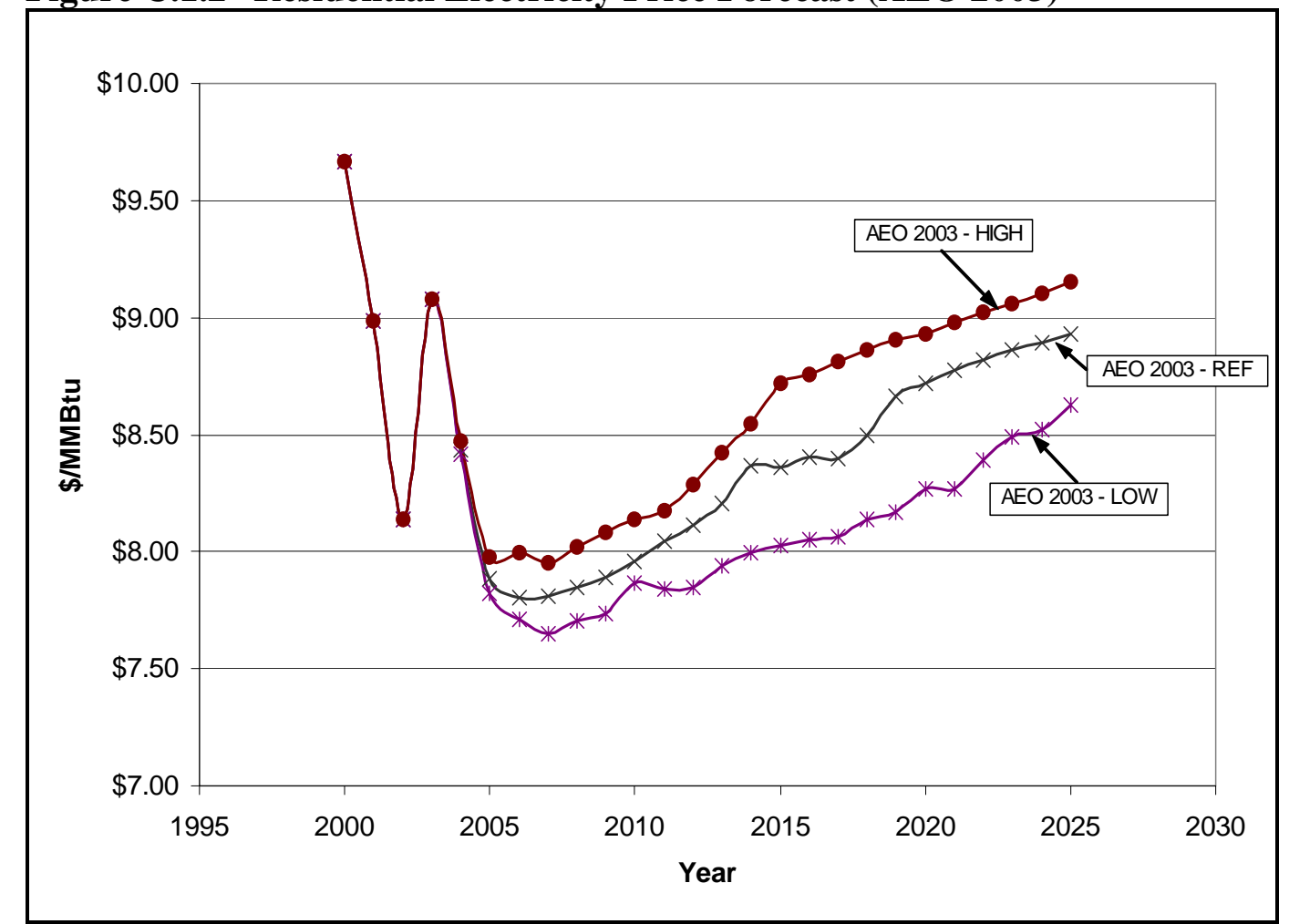

Figure C.1.3 Residential Oil Fuel Price Forecast (AEO 2003)

C-2 


\section{C.2 LCC AND PBP RESULTS USING AEO 2003 HIGH GROWTH PRICE SCENARIO}

Table C.2.1 LCC and PBP Results for Non-Weatherized Gas Furnaces (High Growth)

\begin{tabular}{|c|c|c|c|c|c|c|c|}
\hline \multirow[b]{2}{*}{$\begin{array}{l}\text { Design Option: } \\
\text { AFUE/Electricity }\end{array}$} & \multicolumn{5}{|c|}{ LCC } & \multicolumn{2}{|c|}{ Payback } \\
\hline & Average & $\begin{array}{l}\text { Average } \\
\text { Savings }\end{array}$ & $\begin{array}{l}\text { Net } \\
\text { Cost }\end{array}$ & $\begin{array}{c}\text { No } \\
\text { Impact* }\end{array}$ & $\begin{array}{c}\text { Net } \\
\text { Benefit }\end{array}$ & Median & Average* \\
\hline & $\$$ & $\$$ & $\%$ & $\%$ & $\%$ & years & years \\
\hline $78 \%$ & $\$ 10,264$ & & & & & & \\
\hline $80 \%$ & $\$ 10,087$ & $\$ 0$ & $0 \%$ & $99 \%$ & $1 \%$ & 2.1 & 34.7 \\
\hline $80 \%$ PSC+ & $\$ 10,075$ & $\$ 8$ & $15 \%$ & $27 \%$ & $58 \%$ & 5.3 & 5.1 \\
\hline $80 \%$ ECM & $\$ 10,155$ & $-\$ 51$ & $58 \%$ & $27 \%$ & $16 \%$ & 21.8 & 31.7 \\
\hline $80 \% \mathrm{BC} / \mathrm{ECM}+$ & $\$ 10,098$ & $-\$ 9$ & $48 \%$ & $27 \%$ & $25 \%$ & 16.3 & 24.6 \\
\hline $80 \%$ 2-stage mod. & $\$ 10,006$ & $\$ 44$ & $33 \%$ & $27 \%$ & $40 \%$ & 8.3 & 13.2 \\
\hline 80\% 2-mod. ECM & $\$ 10,071$ & $-\$ 2$ & $45 \%$ & $27 \%$ & $28 \%$ & 14.6 & 20.0 \\
\hline $80 \%$ 2-stage mod. BC/ECM+ & $\$ 10,054$ & $\$ 15$ & $43 \%$ & $27 \%$ & $30 \%$ & 13.6 & 19.9 \\
\hline 81\% 8\% Cat. III & $\$ 10,078$ & $-\$ 1$ & $32 \%$ & $27 \%$ & $42 \%$ & 8.5 & 26.7 \\
\hline 81\% PSC+ & $\$ 10,066$ & $\$ 8$ & $29 \%$ & $26 \%$ & $45 \%$ & 7.7 & 20.3 \\
\hline 81\% ECM & $\$ 10,147$ & $-\$ 53$ & $50 \%$ & $26 \%$ & $24 \%$ & 16.9 & 24.9 \\
\hline 81\% BC/ECM+ & $\$ 10,089$ & $-\$ 10$ & $43 \%$ & $26 \%$ & $31 \%$ & 14.0 & 21.8 \\
\hline 81\% 2-stage Mod, no Cat. III & $\$ 9,964$ & $\$ 68$ & $28 \%$ & $26 \%$ & $46 \%$ & 7.4 & 16.4 \\
\hline 81\% 2-stage Mod ECM & $\$ 10.068$ & $-\$ 7$ & $43 \%$ & $26 \%$ & $31 \%$ & 13.7 & 20.2 \\
\hline 81\% 2-stage Mod BC/ECM+ & $\$ 10,051$ & $\$ 11$ & $41 \%$ & $26 \%$ & $33 \%$ & 13.0 & 19.6 \\
\hline $82 \%$ & $\$ 10,455$ & $-\$ 287$ & $69 \%$ & $26 \%$ & $4 \%$ & 25.1 & 77.5 \\
\hline $82 \%$ PSC+ & $\$ 10,443$ & $-\$ 278$ & $69 \%$ & $26 \%$ & $5 \%$ & 25.2 & 74.6 \\
\hline $82 \%$ ECM & $\$ 10,524$ & $-\$ 339$ & $70 \%$ & $26 \%$ & $4 \%$ & 45.6 & 92.8 \\
\hline $82 \%$ BC/ECM+ & $\$ 10,467$ & $-\$ 297$ & $67 \%$ & $26 \%$ & $7 \%$ & 32.6 & 76.1 \\
\hline 82\% 2-stage Mod & $\$ 10,385$ & $-\$ 249$ & $64 \%$ & $26 \%$ & $10 \%$ & 17.7 & 52.2 \\
\hline 82\% 2-stage Mod ECM & $\$ 10,448$ & $-\$ 295$ & $66 \%$ & $26 \%$ & $8 \%$ & 33.1 & 78.4 \\
\hline 82\% 2-stage Mod BC/ECM+ & $\$ 10,430$ & $-\$ 277$ & $64 \%$ & $26 \%$ & $10 \%$ & 29.2 & 67.7 \\
\hline $83 \%$ & $\$ 10,682$ & $-\$ 462$ & $73 \%$ & $26 \%$ & $1 \%$ & 59.7 & 119.7 \\
\hline 90\% Baseline Cond. & $\$ 10,179$ & $-\$ 134$ & $54 \%$ & $26 \%$ & $19 \%$ & 17.0 & 41.4 \\
\hline $90 \%$ PSC + & $\$ 10,168$ & $-\$ 124$ & $56 \%$ & $15 \%$ & $29 \%$ & 13.7 & 36.8 \\
\hline
\end{tabular}




\begin{tabular}{|c|c|c|c|c|c|c|c|}
\hline $90 \%$ ECM & $\$ 10,260$ & $-\$ 199$ & $64 \%$ & $15 \%$ & $20 \%$ & 20.3 & 45.0 \\
\hline $90 \% \mathrm{BC} / \mathrm{ECM}+$ & $\$ 10,205$ & $-\$ 148$ & $61 \%$ & $15 \%$ & $24 \%$ & 18.0 & 40.2 \\
\hline 91\% 2-stage Mod ECM & $\$ 10,145$ & $-\$ 108$ & $57 \%$ & $15 \%$ & $28 \%$ & 15.7 & 40.5 \\
\hline 91\% 2-stage BC/ECM+ & $\$ 10,120$ & $-\$ 82$ & $55 \%$ & $15 \%$ & $29 \%$ & 15.3 & 36.1 \\
\hline 91\% Step Mod ECM & $\$ 10,363$ & $-\$ 294$ & $65 \%$ & $15 \%$ & $19 \%$ & 20.9 & 51.7 \\
\hline 91\% Step Mod BC/ECM+ & $\$ 10,351$ & $-\$ 270$ & $65 \%$ & $15 \%$ & $20 \%$ & 20.4 & 45.7 \\
\hline 92\%Incr. HX Area & $\$ 10,181$ & $-\$ 143$ & $58 \%$ & $15 \%$ & $26 \%$ & 15.3 & 38.8 \\
\hline $92 \%$ PSC+ & $\$ 10,170$ & $-\$ 132$ & $61 \%$ & $2 \%$ & $37 \%$ & 12.6 & 34.5 \\
\hline $92 \%$ ECM & $\$ 10,263$ & $-\$ 223$ & $74 \%$ & $2 \%$ & $24 \%$ & 20.3 & 45.3 \\
\hline $92 \%$ BC/ECM+ & $\$ 10,208$ & $-\$ 167$ & $71 \%$ & $2 \%$ & $28 \%$ & 18.1 & 38.4 \\
\hline 93\% 2-stage Mod ECM & $\$ 10,154$ & $-\$ 115$ & $64 \%$ & $2 \%$ & $34 \%$ & 15.0 & 38.3 \\
\hline 93\% 2-stage Mod BC/ECM+ & $\$ 10,129$ & $-\$ 90$ & $64 \%$ & $2 \%$ & $35 \%$ & 15.0 & 35.4 \\
\hline 93\% Step Mod ECM & $\$ 10,374$ & $-\$ 333$ & $76 \%$ & $2 \%$ & $23 \%$ & 20.6 & 49.8 \\
\hline 93\% Step Mod BC/ECM+ & $\$ 10,361$ & $-\$ 319$ & $76 \%$ & $2 \%$ & $23 \%$ & 20.3 & 45.0 \\
\hline 96\% Step Mod ECM & $\$ 10,958$ & $-\$ 907$ & $88 \%$ & $2 \%$ & $10 \%$ & 30.7 & 82.8 \\
\hline 96\% Step Mod BC/ECM+ & $\$ 10,967$ & $-\$ 917$ & $90 \%$ & $0 \%$ & $10 \%$ & 31.4 & 84.2 \\
\hline
\end{tabular}

* "No impact" means that the base case furnace assigned to the household has greater efficiency than the level indicated, so the household is not affected. 


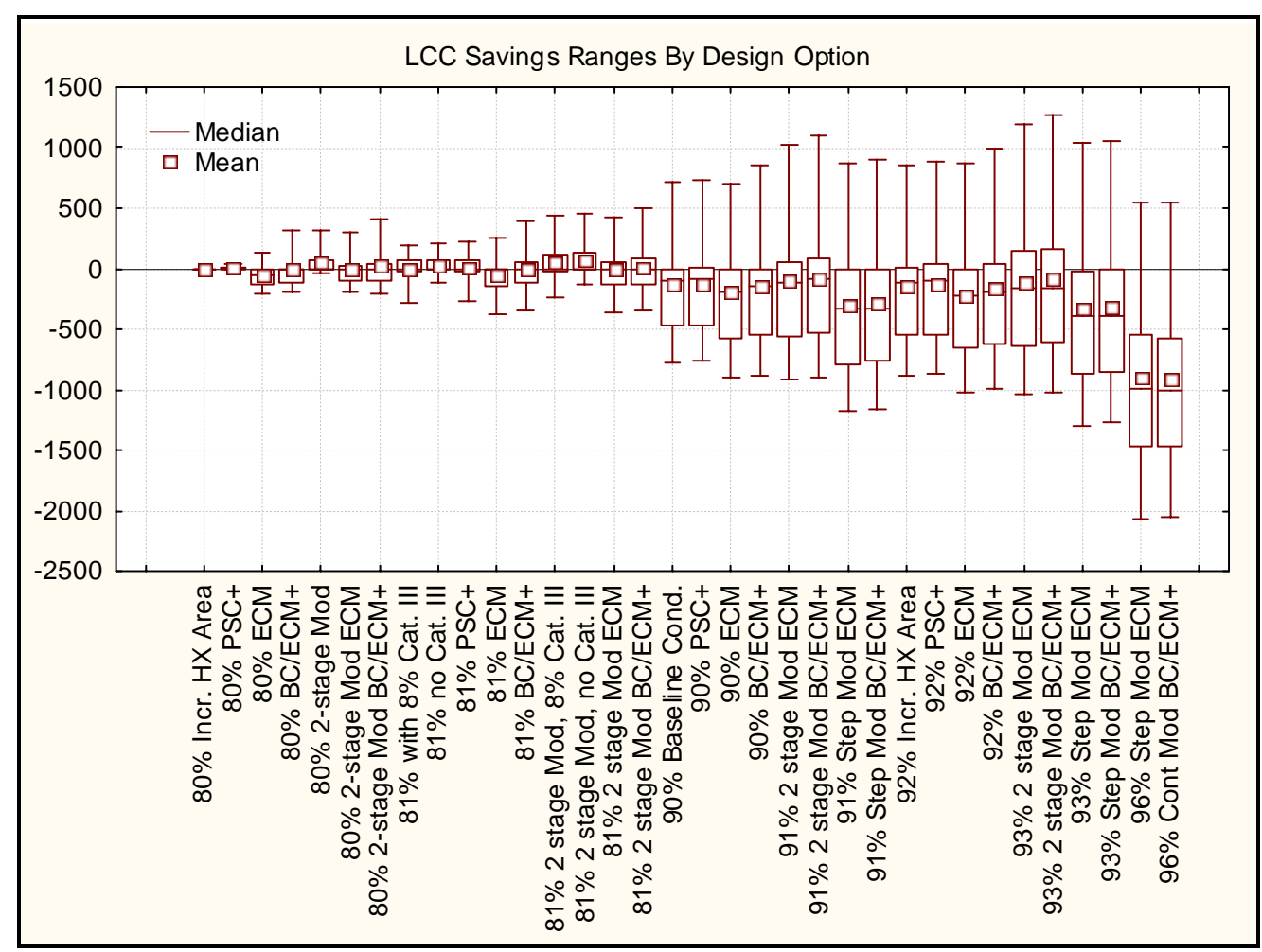

Figure C.2.1 National LCC Savings Results for Non-Weatherized Gas Furnaces (High Growth) 
Table C.2.2 LCC and PBP Results for Weatherized Gas Furnaces (High Growth)

\begin{tabular}{|c|c|c|c|c|c|c|c|}
\hline \multirow[b]{2}{*}{$\begin{array}{l}\text { Design Option: } \\
\text { AFUE/Electricity }\end{array}$} & \multicolumn{5}{|c|}{ LCC } & \multicolumn{2}{|c|}{ Payback } \\
\hline & Average & $\begin{array}{l}\text { Average } \\
\text { Savings }\end{array}$ & $\begin{array}{l}\text { Net } \\
\text { Cost }\end{array}$ & No Impact* & $\begin{array}{c}\text { Net } \\
\text { Benefit }\end{array}$ & Median & Average* \\
\hline 78\% Baseline & $\$ 8,716$ & & & & & & \\
\hline 80\% Incr. HX Area & $\$ 8,625$ & $\$ 2$ & $0 \%$ & $98 \%$ & $2 \%$ & 1.1 & 1.4 \\
\hline 80\% Improved Insulation & $\$ 8,621$ & $\$ 4$ & $25 \%$ & $46 \%$ & $29 \%$ & 9.0 & 8.1 \\
\hline $80 \%$ PSC + & $\$ 8,607$ & $\$ 11$ & $6 \%$ & $46 \%$ & $48 \%$ & 3.2 & 3.9 \\
\hline $80 \%$ ECM & $\$ 8,688$ & $-\$ 32$ & $42 \%$ & $46 \%$ & $13 \%$ & 18.2 & 25.0 \\
\hline 80\% Improved Heat Xfer & $\$ 8,635$ & $-\$ 4$ & $52 \%$ & $46 \%$ & $2 \%$ & 2.7 & 3.4 \\
\hline 81\% Incr. HX Area & $\$ 8,584$ & $\$ 24$ & $2 \%$ & $46 \%$ & $52 \%$ & 1.9 & 2.5 \\
\hline 81\% Improved Insulation & $\$ 8,580$ & $\$ 27$ & $19 \%$ & $20 \%$ & $61 \%$ & 5.0 & 6.2 \\
\hline $81 \%$ PSC + & $\$ 8,566$ & $\$ 38$ & $4 \%$ & $20 \%$ & $76 \%$ & 2.7 & 3.2 \\
\hline 81\% ECM & $\$ 8,647$ & $-\$ 27$ & $55 \%$ & $20 \%$ & $25 \%$ & 15.2 & 20.0 \\
\hline 81\% Improved Heat Xfer & $\$ 8,590$ & $\$ 19$ & $32 \%$ & $20 \%$ & $48 \%$ & 3.7 & 4.9 \\
\hline 82\% Incr. HX Area & $\$ 8,544$ & $\$ 55$ & $3 \%$ & $20 \%$ & $78 \%$ & 2.0 & 2.8 \\
\hline 82\% Improved Insulation & $\$ 8,541$ & $\$ 59$ & $18 \%$ & $0 \%$ & $82 \%$ & 4.2 & 5.4 \\
\hline $82 \%$ PSC+ & $\$ 8,527$ & $\$ 73$ & $3 \%$ & $0 \%$ & $97 \%$ & 2.5 & 3.1 \\
\hline $82 \%$ ECM & $\$ 8,608$ & $-\$ 8$ & $62 \%$ & $0 \%$ & $38 \%$ & 13.4 & 17.4 \\
\hline 82\% Improved Heat Xfer & $\$ 8,546$ & $\$ 54$ & $24 \%$ & $0 \%$ & $76 \%$ & 2.4 & 3.3 \\
\hline 83\% Incr. HX Area & $\$ 8,510$ & $\$ 90$ & $6 \%$ & $0 \%$ & $94 \%$ & 2.8 & 3.8 \\
\hline 83\% Improved Insulation & $\$ 8,507$ & $\$ 93$ & $11 \%$ & $0 \%$ & $89 \%$ & 3.8 & 5.2 \\
\hline $83 \%$ PSC+ & $\$ 8,493$ & $\$ 107$ & $3 \%$ & $0 \%$ & $97 \%$ & 2.8 & 3.5 \\
\hline 83\% ECM & $\$ 8,574$ & $\$ 26$ & $54 \%$ & $0 \%$ & $46 \%$ & 11.7 & 14.2 \\
\hline 83\% Improved Heat Xfer & $\$ 8,507$ & $\$ 92$ & $4 \%$ & $0 \%$ & $96 \%$ & 2.3 & 3.2 \\
\hline
\end{tabular}

"No impact" means that the base case furnace assigned to the household has greater efficiency than the level indicated, so the household is not affected. 


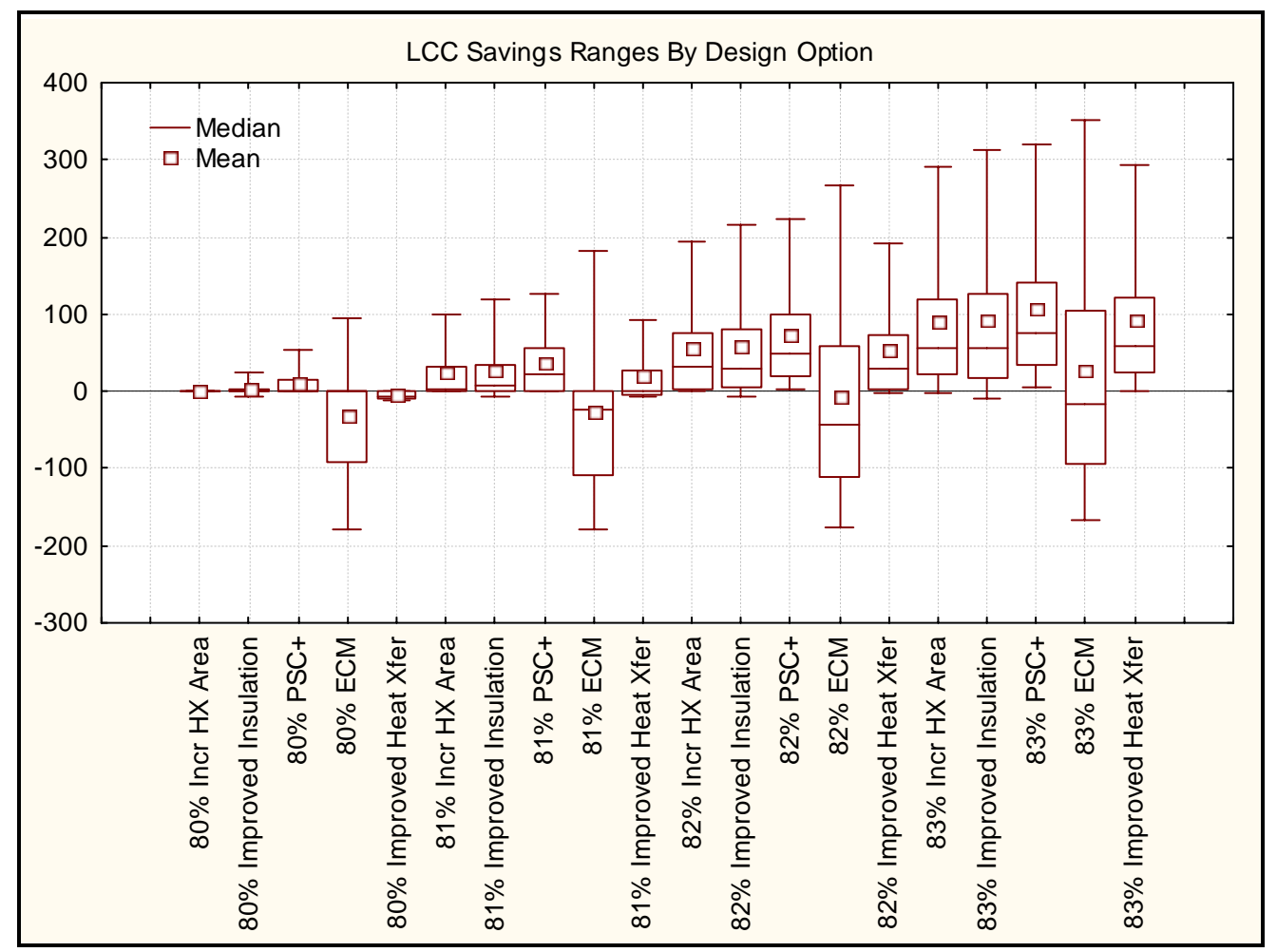

Figure C.2.2 National LCC Savings Results for Weatherized Furnaces (High Growth) 
Table C.2.3 LCC and PBP Results for Manufactured Home Furnaces (High Growth)

\begin{tabular}{|l|c|c|c|c|c|c|c|}
\hline & \multicolumn{3}{|c|}{ LCC } & \multicolumn{2}{c|}{ Payback } \\
\hline $\begin{array}{l}\text { Design Option: } \\
\text { AFUE/Electricity }\end{array}$ & $\begin{array}{c}\text { Average } \\
\text { LCC }\end{array}$ & $\begin{array}{c}\text { Average } \\
\text { Savings }\end{array}$ & $\begin{array}{c}\text { Net } \\
\text { Cost }\end{array}$ & $\begin{array}{c}\text { No } \\
\text { Impact* }\end{array}$ & $\begin{array}{c}\text { Net } \\
\text { Benefit }\end{array}$ & Median & Average* \\
\hline $75 \%$ Baseline & $\$ 8,179$ & & & & & \\
\hline $80 \%$ & $\$ 7,728$ & $\$ 69$ & $1 \%$ & $85 \%$ & $14 \%$ & 2.2 & 4.4 \\
\hline $80 \%$ ECM & $\$ 7,807$ & $-\$ 5$ & $65 \%$ & $5 \%$ & $30 \%$ & 18.9 & 35.7 \\
\hline $80 \%$ 2-stage modulation & $\$ 7,938$ & $-\$ 156$ & $79 \%$ & $5 \%$ & $16 \%$ & 25.2 & 60.8 \\
\hline $81 \%$ & $\$ 7,674$ & $\$ 120$ & $9 \%$ & $5 \%$ & $86 \%$ & 4.1 & 6.0 \\
\hline $81 \%$ ECM & $\$ 7,752$ & $\$ 47$ & $54 \%$ & $5 \%$ & $41 \%$ & 14.6 & 20.1 \\
\hline $81 \%$ 2-stage modulation & $\$ 7,888$ & $-\$ 109$ & $74 \%$ & $5 \%$ & $21 \%$ & 24.3 & 59.0 \\
\hline $82 \%$ & $\$ 7,628$ & $\$ 164$ & $13 \%$ & $5 \%$ & $82 \%$ & 4.9 & 7.2 \\
\hline $82 \%$ ECM & $\$ 7,706$ & $\$ 90$ & $45 \%$ & $5 \%$ & $50 \%$ & 12.6 & 16.5 \\
\hline $82 \%$ 2-stage modulation & $\$ 7,846$ & $-\$ 69$ & $69 \%$ & $5 \%$ & $26 \%$ & 22.2 & 55.0 \\
\hline $90 \%$ & $\$ 7,574$ & $\$ 215$ & $44 \%$ & $5 \%$ & $51 \%$ & 11.7 & 21.6 \\
\hline
\end{tabular}
indicated, so the household is not affected. 


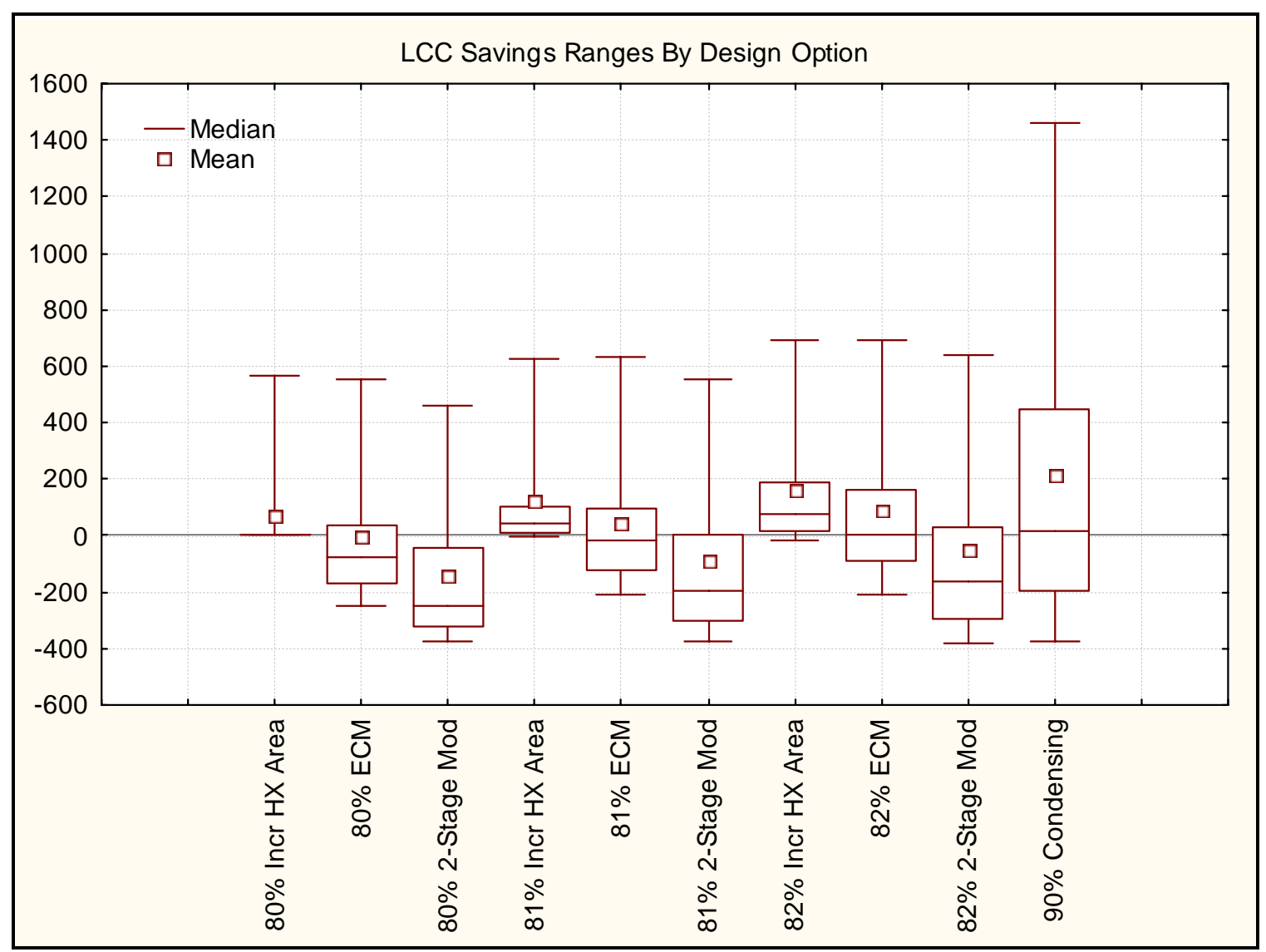

Figure C.2.3 National LCC Savings Results for Manufactured Home Furnaces (High Growth) 
Table C.2.4 LCC and PBP Results for Oil Furnaces (High Growth)

\begin{tabular}{|c|c|c|c|c|c|c|c|}
\hline \multirow[b]{2}{*}{$\begin{array}{l}\text { Design Option: } \\
\text { AFUE/Electricity }\end{array}$} & \multicolumn{5}{|c|}{ LCC } & \multicolumn{2}{|c|}{ Payback } \\
\hline & Average & $\begin{array}{l}\text { Average } \\
\text { Savings }\end{array}$ & $\begin{array}{l}\text { Net } \\
\text { Cost }\end{array}$ & $\begin{array}{c}\text { No } \\
\text { Impact* }\end{array}$ & $\begin{array}{c}\text { Net } \\
\text { Benefit }\end{array}$ & Median & Average* \\
\hline 78\% AFUE - Baseline & $\$ 16,584$ & & & & & & \\
\hline 80\% AFUE- Incr. HX Area & $\$ 16,281$ & $\$ 12$ & $0 \%$ & $96 \%$ & $4 \%$ & 0.2 & 0.2 \\
\hline 81\% AFUE- Incr. HX Area & $\$ 16,138$ & $\$ 98$ & $2 \%$ & $39 \%$ & $59 \%$ & 0.4 & 0.5 \\
\hline 81\% AFUE Atom Burner 2-stage Mod. & $\$ 16,258$ & $\$ 13$ & $42 \%$ & $30 \%$ & $28 \%$ & 11.5 & 14.1 \\
\hline 81\% AFUE Interrupted Ignition & $\$ 16,160$ & $\$ 82$ & $12 \%$ & $30 \%$ & $58 \%$ & 2.7 & 4.8 \\
\hline $\begin{array}{l}\text { 81\% AFUE } \\
\text { ImprovedSupplyFanMotor(ECM) }\end{array}$ & $\$ 16,313$ & $-\$ 24$ & $49 \%$ & $30 \%$ & $21 \%$ & 13.7 & 21.6 \\
\hline 82\% AFUE- Incr. HX Area & $\$ 15,997$ & $\$ 196$ & $2 \%$ & $30 \%$ & $68 \%$ & 0.3 & 0.4 \\
\hline 82\% AFUE Atom Burner 2-stage Mod. & $\$ 16,123$ & $\$ 98$ & $34 \%$ & $22 \%$ & $43 \%$ & 8.4 & 13.7 \\
\hline 82\% AFUE Interrupted Ignition & $\$ 16,019$ & $\$ 179$ & $10 \%$ & $22 \%$ & $68 \%$ & 1.6 & 3.5 \\
\hline $\begin{array}{l}\text { 82\%AFUE } \\
\text { ImprovedSupplyFanMotor(ECM) }\end{array}$ & $\$ 16,171$ & $\$ 62$ & $37 \%$ & $22 \%$ & $40 \%$ & 8.8 & 16.0 \\
\hline 83\% AFUE- Incr. HX Area & $\$ 15,860$ & $\$ 302$ & $3 \%$ & $22 \%$ & $75 \%$ & 0.3 & 0.4 \\
\hline 83\% AFUE Atom Burner 2-stage Mod. & $\$ 15,991$ & $\$ 190$ & $30 \%$ & $15 \%$ & $55 \%$ & 6.7 & 11.2 \\
\hline 83\% AFUE Interrupted Ignition & $\$ 15,882$ & $\$ 284$ & $10 \%$ & $15 \%$ & $75 \%$ & 1.3 & 2.9 \\
\hline $\begin{array}{l}\text { 83\%AFUE } \\
\text { ImprovedSupplyFanMotor(ECM) }\end{array}$ & $\$ 16,033$ & $\$ 154$ & $31 \%$ & $15 \%$ & $54 \%$ & 6.8 & 14.3 \\
\hline 84\% AFUE- Incr. HX Area & $\$ 16,331$ & $-\$ 98$ & $56 \%$ & $15 \%$ & $29 \%$ & 13.3 & 20.3 \\
\hline 84\% AFUE Atom Burner 2-stage Mod. & $\$ 16,467$ & $-\$ 225$ & $69 \%$ & $7 \%$ & $23 \%$ & 16.0 & 24.8 \\
\hline 84\% AFUE Interrupted Ignition & $\$ 16,352$ & $-\$ 119$ & $65 \%$ & $7 \%$ & $28 \%$ & 14.1 & 20.7 \\
\hline $\begin{array}{l}\text { 84\%AFUE } \\
\text { ImprovedSupplyFanMotor(ECM) }\end{array}$ & $\$ 16,504$ & $-\$ 259$ & $73 \%$ & $7 \%$ & $20 \%$ & 17.0 & 31.4 \\
\hline 85\% AFUE- Incr. HX Area & $\$ 16,205$ & $\$ 17$ & $47 \%$ & $7 \%$ & $45 \%$ & 9.7 & 13.5 \\
\hline 85\% AFUE Atom Burner 2-stage Mod. & $\$ 16,346$ & $-\$ 124$ & $68 \%$ & $0 \%$ & $32 \%$ & 13.5 & 19.9 \\
\hline 85\% AFUE Interrupted Ignition & $\$ 16,227$ & $-\$ 4$ & $56 \%$ & $0 \%$ & $44 \%$ & 10.5 & 14.6 \\
\hline $\begin{array}{l}\text { 85\%AFUE } \\
\text { ImprovedSupplyFanMotor(ECM) }\end{array}$ & $\$ 16,378$ & $-\$ 155$ & $70 \%$ & $0 \%$ & $30 \%$ & 14.1 & 26.1 \\
\hline
\end{tabular}

* "No impact" means that the base case furnace assigned to the household has greater efficiency than the level indicated, so the household is not affected. 


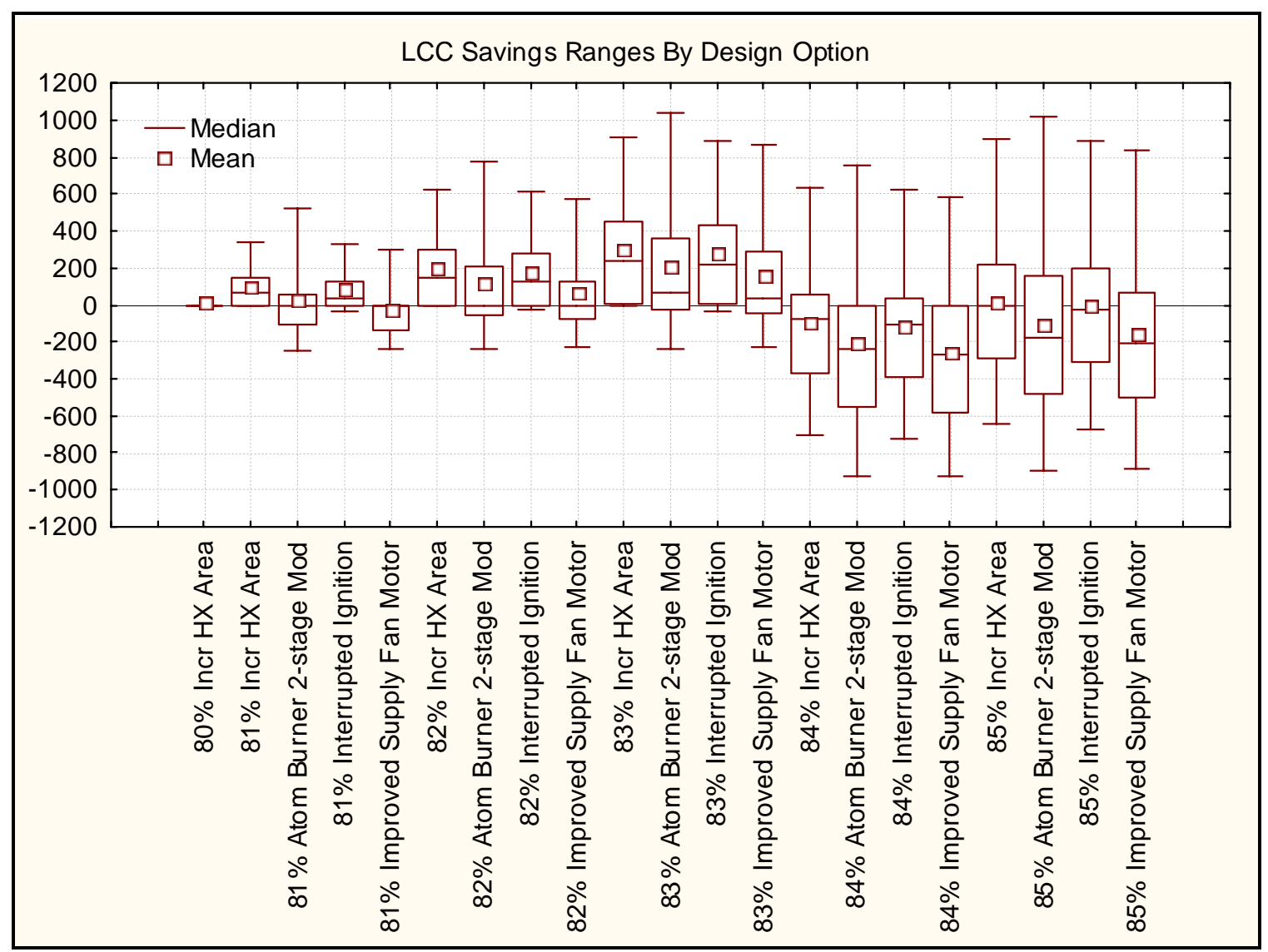

Figure C.2.4 National LCC Savings Results for Oil Furnaces (High Growth) 
Table C.2.5 LCC and PBP Results for Gas Boilers (High Growth)

\begin{tabular}{|c|c|c|c|c|c|c|c|}
\hline \multirow[b]{2}{*}{$\begin{array}{l}\text { Design Option: } \\
\text { AFUE/Electricity }\end{array}$} & \multicolumn{5}{|c|}{ LCC } & \multicolumn{2}{|c|}{ Payback } \\
\hline & $\begin{array}{c}\text { Average } \\
\text { LCC }\end{array}$ & $\begin{array}{l}\text { Average } \\
\text { Savings }\end{array}$ & $\begin{array}{l}\text { Net } \\
\text { Cost }\end{array}$ & $\begin{array}{c}\text { No } \\
\text { Impact* }\end{array}$ & $\begin{array}{c}\text { Net } \\
\text { Benefit }\end{array}$ & Median & Average* \\
\hline 80\% Baseline & $\$ 10,876$ & & & & & & \\
\hline $81 \%$ & $\$ 10,601$ & $\$ 96$ & $0 \%$ & $65 \%$ & $35 \%$ & 2.1 & 2.3 \\
\hline $81 \%$ 2-stage modulation & $\$ 10,837$ & $-\$ 37$ & $38 \%$ & $44 \%$ & $18 \%$ & 9.6 & 14.4 \\
\hline 81\% Imp Circ Pump & $\$ 10,848$ & $-\$ 43$ & $40 \%$ & $44 \%$ & $17 \%$ & 14.5 & 53.6 \\
\hline $82 \%$ & $\$ 10,542$ & $\$ 130$ & $3 \%$ & $44 \%$ & $54 \%$ & 2.4 & 3.1 \\
\hline $82 \%$ 2-stage modulation & $\$ 10,777$ & $-\$ 36$ & $48 \%$ & $30 \%$ & $22 \%$ & 8.9 & 18.8 \\
\hline 82\% Imp Circ Pump & $\$ 10,789$ & $-\$ 44$ & $50 \%$ & $30 \%$ & $20 \%$ & 18.3 & 41.3 \\
\hline $83 \%$ & $\$ 10,480$ & $\$ 173$ & $4 \%$ & $30 \%$ & $66 \%$ & 2.4 & 3.2 \\
\hline 83\% 2-stage modulation & $\$ 10,716$ & $-\$ 28$ & $58 \%$ & $15 \%$ & $27 \%$ & 9.4 & 22.3 \\
\hline 83\% Imp Circ Pump & $\$ 10,728$ & $-\$ 37$ & $60 \%$ & $15 \%$ & $25 \%$ & 17.0 & 38.1 \\
\hline $84 \%$ & $\$ 10,421$ & $\$ 224$ & $6 \%$ & $15 \%$ & $79 \%$ & 2.4 & 3.3 \\
\hline $84 \%$ 2-stage modulation & $\$ 10,656$ & $\$ 2$ & $61 \%$ & $6 \%$ & $33 \%$ & 10.0 & 21.9 \\
\hline 84\% Imp Circ Pump & $\$ 10,669$ & $-\$ 9$ & $62 \%$ & $6 \%$ & $32 \%$ & 14.4 & 30.2 \\
\hline $88 \%$ & $\$ 10,954$ & $-\$ 276$ & $66 \%$ & $6 \%$ & $28 \%$ & 16.8 & 28.7 \\
\hline $91 \%$ & $\$ 11,027$ & $-\$ 346$ & $73 \%$ & $3 \%$ & $24 \%$ & 18.1 & 39.7 \\
\hline $99 \%$ & $\$ 11,492$ & $-\$ 811$ & $84 \%$ & $0 \%$ & $16 \%$ & 20.5 & 41.6 \\
\hline
\end{tabular}

"No impact" means that the base case furnace assigned to the household has greater efficiency than the level indicated, so the household is not affected. 


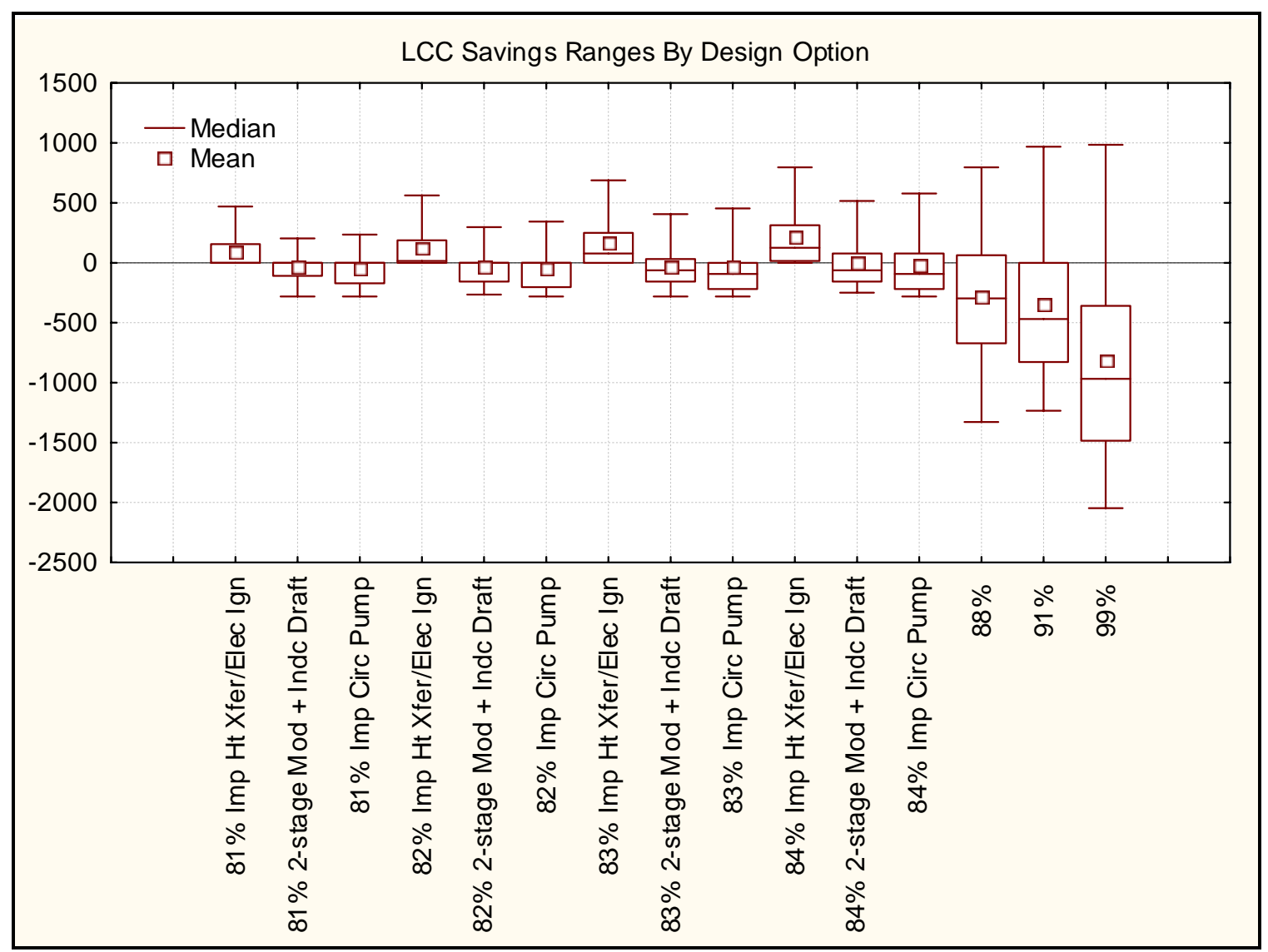

Figure C.2.5 National LCC Savings Results for Gas Boilers (High Growth) 
Table C.2.6 LCC and PBP Results for Oil Boilers (High Growth)

\begin{tabular}{|c|c|c|c|c|c|c|c|}
\hline \multirow[b]{2}{*}{$\begin{array}{l}\text { Design Option: } \\
\text { AFUE/Electricity }\end{array}$} & \multicolumn{5}{|c|}{ LCC } & \multicolumn{2}{|c|}{ Payback } \\
\hline & Average & $\begin{array}{l}\text { Average } \\
\text { Savings }\end{array}$ & $\begin{array}{l}\text { Net } \\
\text { Cost }\end{array}$ & $\begin{array}{c}\text { No } \\
\text { Impact* }\end{array}$ & $\begin{array}{c}\text { Net } \\
\text { Benefit }\end{array}$ & Median & Average* \\
\hline $80 \%$ & $\$ 15,210$ & & & & & & \\
\hline $81 \%$ & $\$ 15,088$ & $\$ 6$ & $0 \%$ & $95 \%$ & $5 \%$ & 0.6 & 0.8 \\
\hline 81\% Atomized Burner & $\$ 15,491$ & $-\$ 36$ & $11 \%$ & $89 \%$ & $0 \%$ & 70.5 & 105.0 \\
\hline 81\% Inter Ign & $\$ 15,090$ & $\$ 6$ & $4 \%$ & $89 \%$ & $7 \%$ & 5.7 & 9.0 \\
\hline 81\% Imp Circ Pump & $\$ 15,309$ & $-\$ 17$ & $10 \%$ & $89 \%$ & $1 \%$ & 37.5 & 60.2 \\
\hline $82 \%$ & $\$ 14,969$ & $\$ 19$ & $0 \%$ & $89 \%$ & $11 \%$ & 0.6 & 0.8 \\
\hline 82\% Atomized Burner & $\$ 15,373$ & $-\$ 46$ & $16 \%$ & $84 \%$ & $0 \%$ & 33.6 & 61.0 \\
\hline 82\% Inter Ign & $\$ 14,971$ & $\$ 19$ & $4 \%$ & $84 \%$ & $12 \%$ & 3.3 & 6.4 \\
\hline 82\% Imp Circ Pump & $\$ 15,190$ & $-\$ 16$ & $13 \%$ & $84 \%$ & $3 \%$ & 20.3 & 42.2 \\
\hline $83 \%$ & $\$ 14,853$ & $\$ 38$ & $0 \%$ & $84 \%$ & $16 \%$ & 0.6 & 0.8 \\
\hline 83\% Atomized Burner & $\$ 15,257$ & $-\$ 120$ & $37 \%$ & $61 \%$ & $2 \%$ & 23.3 & 44.8 \\
\hline 83\% Inter Ign & $\$ 14,855$ & $\$ 37$ & $16 \%$ & $61 \%$ & $24 \%$ & 7.5 & 9.5 \\
\hline 83\% Imp Circ Pump & $\$ 15,075$ & $-\$ 50$ & $33 \%$ & $61 \%$ & $7 \%$ & 49.9 & 63.8 \\
\hline $84 \%$ & $\$ 14,740$ & $\$ 82$ & $0 \%$ & $61 \%$ & $39 \%$ & 0.7 & 0.8 \\
\hline 84\% Atomized Burner & $\$ 15,144$ & $-\$ 172$ & $58 \%$ & $37 \%$ & $5 \%$ & 25.9 & 55.3 \\
\hline 84\% Inter Ign & $\$ 14,742$ & $\$ 80$ & $16 \%$ & $37 \%$ & $47 \%$ & 3.7 & 7.1 \\
\hline 84\% Imp Circ Pump & $\$ 14,962$ & $-\$ 57$ & $51 \%$ & $37 \%$ & $12 \%$ & 23.2 & 47.1 \\
\hline $86 \%$ & $\$ 15,241$ & $-\$ 227$ & $51 \%$ & $37 \%$ & $11 \%$ & 22.4 & 30.9 \\
\hline 86\% Atomized Burner & $\$ 15,645$ & $-\$ 603$ & $91 \%$ & $7 \%$ & $2 \%$ & 53.7 & 102.2 \\
\hline 86\% Inter Ign & $\$ 15,243$ & $-\$ 229$ & $71 \%$ & $7 \%$ & $22 \%$ & 17.0 & 24.2 \\
\hline 86\% Imp Circ Pump & $\$ 15,463$ & $-\$ 433$ & $87 \%$ & $7 \%$ & $6 \%$ & 39.9 & 56.8 \\
\hline $90 \%$ & $\$ 15,541$ & $-\$ 505$ & $80 \%$ & $7 \%$ & $13 \%$ & 19.0 & 23.1 \\
\hline $95 \%$ & $\$ 15,828$ & $-\$ 791$ & $87 \%$ & $0 \%$ & $13 \%$ & 18.6 & 22.5 \\
\hline
\end{tabular}

* "No impact" means that the base case furnace assigned to the household has greater efficiency than the level indicated, so the household is not affected. 


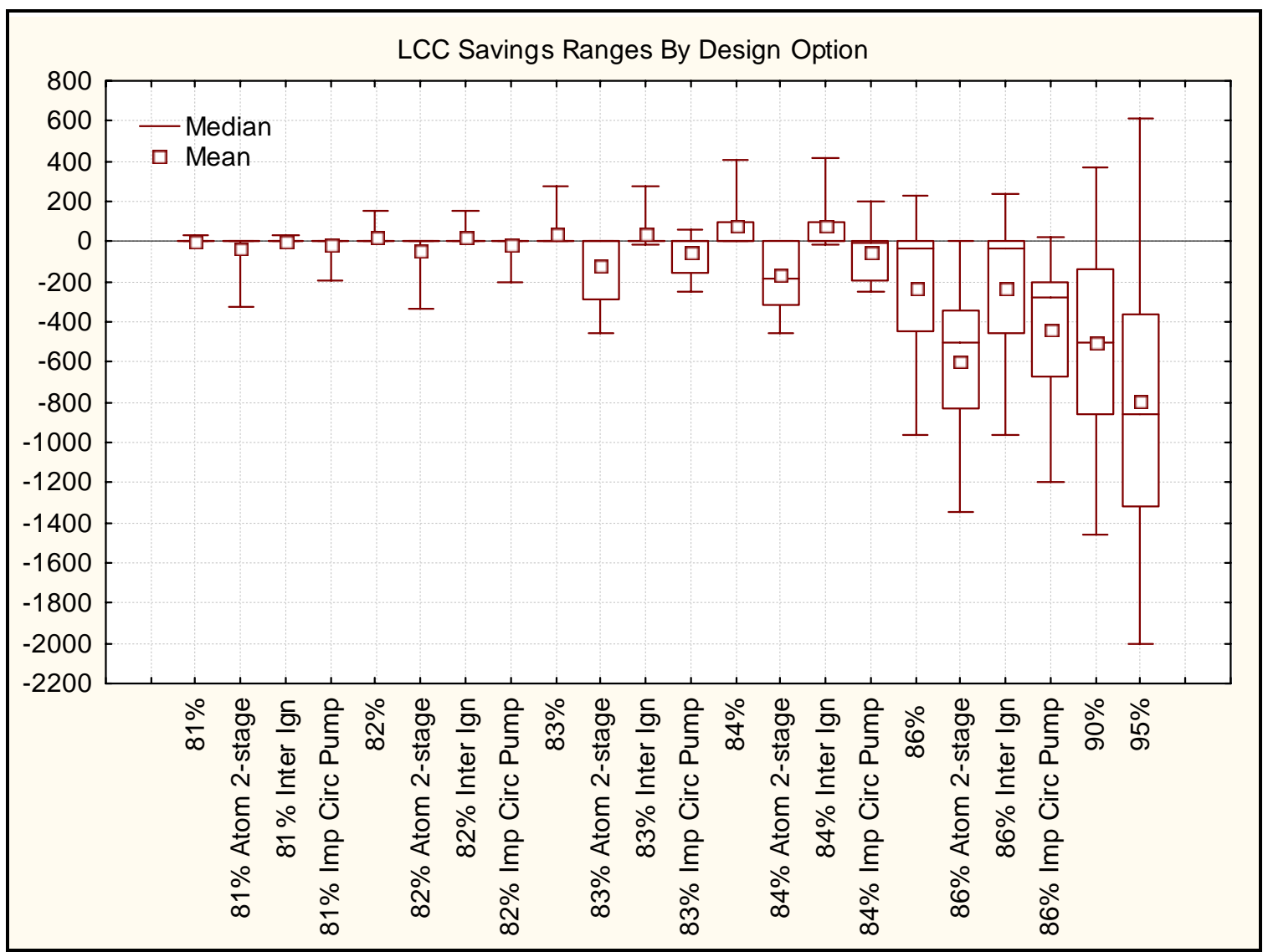

Figure C.2.6 National LCC Savings Results for Oil Boilers (High Growth) 


\section{C.3 LCC AND PBP RESULTS USING AEO 2003 LOW GROWTH PRICE SCENARIO}

Table C.3.1 LCC and PBP Results for Non-Weatherized Gas Furnaces (Low Growth)

\begin{tabular}{|c|c|c|c|c|c|c|c|}
\hline \multirow[b]{2}{*}{$\begin{array}{l}\text { Design Option: } \\
\text { AFUE/Electricity }\end{array}$} & \multicolumn{5}{|c|}{ LCC } & \multicolumn{2}{|c|}{ Payback } \\
\hline & Average & $\begin{array}{l}\text { Average } \\
\text { Savings }\end{array}$ & $\begin{array}{l}\text { Net } \\
\text { Cost }\end{array}$ & $\begin{array}{c}\text { No } \\
\text { Impact* }\end{array}$ & $\begin{array}{c}\text { Net } \\
\text { Benefit }\end{array}$ & Median & Average* \\
\hline & $\$$ & $\$$ & $\%$ & $\%$ & $\%$ & years & years \\
\hline $78 \%$ & $\$ 9,855$ & & & & & & \\
\hline $80 \%$ & $\$ 9,687$ & $\$ 0$ & $0 \%$ & $99 \%$ & $1 \%$ & 2.1 & 38.5 \\
\hline $80 \%$ PSC+ & $\$ 9,678$ & $\$ 7$ & $18 \%$ & $27 \%$ & $55 \%$ & 5.4 & 5.4 \\
\hline 80\% ECM & $\$ 9,774$ & $-\$ 65$ & $61 \%$ & $27 \%$ & $12 \%$ & 24.1 & 35.2 \\
\hline $80 \%$ BC/ECM+ & $\$ 9,726$ & $-\$ 29$ & $53 \%$ & $27 \%$ & $21 \%$ & 18.0 & 27.5 \\
\hline 80\% 2-stage mod. & $\$ 9,612$ & $\$ 41$ & $33 \%$ & $27 \%$ & $40 \%$ & 8.7 & 13.7 \\
\hline 80\% 2-mod. ECM & $\$ 9,699$ & $-\$ 21$ & $49 \%$ & $27 \%$ & $24 \%$ & 16.1 & 21.9 \\
\hline $\begin{array}{l}\text { 80\% 2-stage mod. } \\
\text { BC/ECM+ }\end{array}$ & $\$ 9,689$ & $-\$ 9$ & $47 \%$ & $27 \%$ & $26 \%$ & 14.9 & 21.8 \\
\hline 81\% 8\% Cat. III & $\$ 9,683$ & $-\$ 4$ & $32 \%$ & $27 \%$ & $41 \%$ & 9.2 & 28.3 \\
\hline 81\% PSC+ & $\$ 9,673$ & $\$ 3$ & $30 \%$ & $26 \%$ & $43 \%$ & 8.3 & 21.9 \\
\hline 81\% ECM & $\$ 9,770$ & $-\$ 69$ & $53 \%$ & $26 \%$ & $21 \%$ & 18.5 & 27.3 \\
\hline 81\% BC/ECM+ & $\$ 9,722$ & $-\$ 33$ & $47 \%$ & $26 \%$ & $27 \%$ & 15.4 & 23.9 \\
\hline $\begin{array}{l}81 \% \text { 2-stage Mod, no Cat. } \\
\text { III }\end{array}$ & $\$ 9,574$ & $\$ 62$ & $29 \%$ & $26 \%$ & $45 \%$ & 7.8 & 17.3 \\
\hline 81\% 2-stage Mod ECM & $\$ 9,701$ & $-\$ 29$ & $46 \%$ & $26 \%$ & $28 \%$ & 14.9 & 21.9 \\
\hline $\begin{array}{l}\text { 81\% 2-stage Mod } \\
\text { BC/ECM+ }\end{array}$ & $\$ 9,690$ & $-\$ 16$ & $44 \%$ & $26 \%$ & $30 \%$ & 14.3 & 21.3 \\
\hline $82 \%$ & $\$ 10,064$ & $-\$ 293$ & $70 \%$ & $26 \%$ & $4 \%$ & 28.7 & 86.4 \\
\hline $82 \%$ PSC+ & $\$ 10,055$ & $-\$ 286$ & $69 \%$ & $26 \%$ & $4 \%$ & 29.2 & 85.3 \\
\hline $82 \%$ ECM & $\$ 10,151$ & $-\$ 358$ & $71 \%$ & $26 \%$ & $3 \%$ & 51.4 & 109.2 \\
\hline $82 \%$ BC/ECM+ & $\$ 10,104$ & $-\$ 322$ & $68 \%$ & $26 \%$ & $6 \%$ & 36.6 & 83.4 \\
\hline 82\% 2-stage Mod & $\$ 9,998$ & $-\$ 258$ & $65 \%$ & $26 \%$ & $9 \%$ & 19.3 & 59.8 \\
\hline 82\% 2-stage Mod ECM & $\$ 10,084$ & $-\$ 319$ & $67 \%$ & $26 \%$ & $6 \%$ & 36.1 & 84.9 \\
\hline $\begin{array}{l}\text { 82\% 2-stage Mod } \\
\text { BC/ECM+ }\end{array}$ & $\$ 10,073$ & $-\$ 306$ & $66 \%$ & $26 \%$ & $7 \%$ & 32.4 & 73.9 \\
\hline $83 \%$ & $\$ 10,296$ & $-\$ 470$ & $73 \%$ & $26 \%$ & $1 \%$ & 66.4 & 120.5 \\
\hline 90\% Baseline Cond. & $\$ 9,820$ & $-\$ 161$ & $56 \%$ & $26 \%$ & $18 \%$ & 18.5 & 42.5 \\
\hline $90 \%$ PSC+ & $\$ 9,811$ & $-\$ 152$ & $58 \%$ & $15 \%$ & $27 \%$ & 14.8 & 38.0 \\
\hline
\end{tabular}

C-16 


\begin{tabular}{|c|c|c|c|c|c|c|c|}
\hline $90 \%$ ECM & $\$ 9,917$ & $-\$ 239$ & $67 \%$ & $15 \%$ & $18 \%$ & 22.4 & 48.8 \\
\hline $90 \% \mathrm{BC} / \mathrm{ECM}+$ & $\$ 9,871$ & $-\$ 196$ & $64 \%$ & $15 \%$ & $20 \%$ & 19.9 & 44.1 \\
\hline 91\% 2-stage Mod ECM & $\$ 9,811$ & $-\$ 156$ & $59 \%$ & $15 \%$ & $25 \%$ & 17.1 & 41.0 \\
\hline 91\% 2-stage BC/ECM+ & $\$ 9,794$ & $-\$ 137$ & $59 \%$ & $15 \%$ & $26 \%$ & 16.8 & 39.6 \\
\hline 91\% Step Mod ECM & $\$ 10,032$ & $-\$ 344$ & $67 \%$ & $15 \%$ & $17 \%$ & 22.9 & 53.8 \\
\hline 91\% Step Mod BC/ECM+ & $\$ 10,027$ & $-\$ 334$ & $67 \%$ & $15 \%$ & $17 \%$ & 22.4 & 50.5 \\
\hline 92\%Incr. HX Area & $\$ 9,829$ & $-\$ 174$ & $60 \%$ & $15 \%$ & $24 \%$ & 16.6 & 41.0 \\
\hline $92 \%$ PSC+ & $\$ 9,820$ & $-\$ 166$ & $64 \%$ & $2 \%$ & $34 \%$ & 13.6 & 37.1 \\
\hline $92 \%$ ECM & $\$ 9,927$ & $-\$ 271$ & $77 \%$ & $2 \%$ & $21 \%$ & 22.1 & 47.5 \\
\hline $92 \% \mathrm{BC} / \mathrm{ECM}+$ & $\$ 9,880$ & $-\$ 224$ & $74 \%$ & $2 \%$ & $24 \%$ & 19.9 & 41.3 \\
\hline 93\% 2-stage Mod ECM & $\$ 9,827$ & $-\$ 173$ & $68 \%$ & $2 \%$ & $31 \%$ & 16.3 & 40.4 \\
\hline $\begin{array}{l}\text { 93\% 2-stage Mod } \\
\text { BC/ECM+ }\end{array}$ & $\$ 9,809$ & $-\$ 154$ & $67 \%$ & $2 \%$ & $31 \%$ & 16.3 & 36.2 \\
\hline 93\% Step Mod ECM & $\$ 10,050$ & $-\$ 392$ & $78 \%$ & $2 \%$ & $20 \%$ & 22.4 & 51.7 \\
\hline 93\% Step Mod BC/ECM+ & $\$ 10,043$ & $-\$ 384$ & $79 \%$ & $2 \%$ & $20 \%$ & 22.4 & 47.2 \\
\hline 96\% Step Mod ECM & $\$ 10,642$ & $-\$ 976$ & $90 \%$ & $2 \%$ & $8 \%$ & 33.4 & 92.2 \\
\hline 96\% Step Mod BC/ECM+ & $\$ 10,658$ & $-\$ 992$ & $92 \%$ & $0 \%$ & $9 \%$ & 34.2 & 87.0 \\
\hline
\end{tabular}

"No impact" means that the base case furnace assigned to the household has greater efficiency than the level indicated, so the household is not affected. 


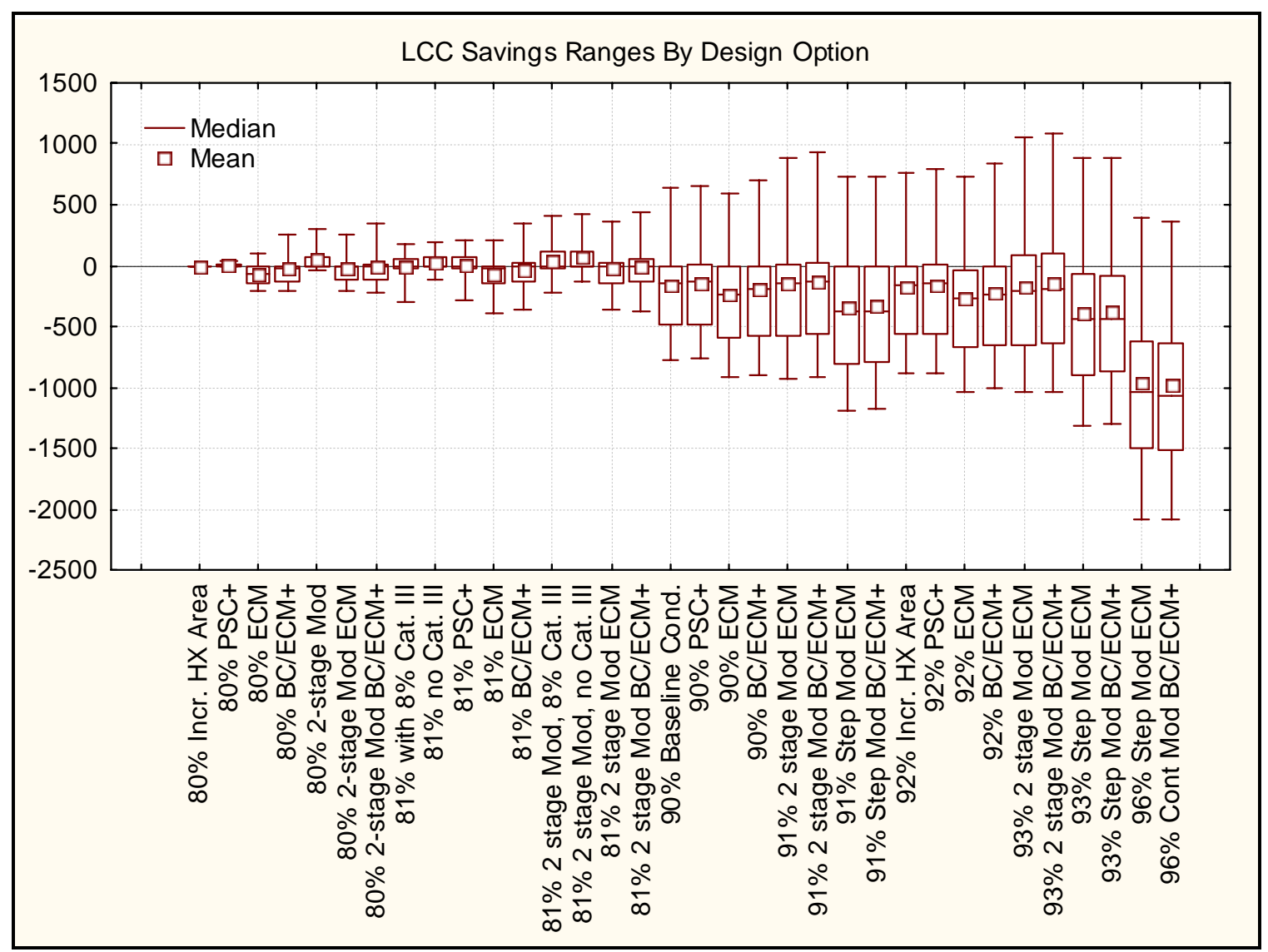

Figure C.3.1 National LCC Savings Results for Non-Weatherized Gas Furnaces (Low Growth) 
Table C.3.2 LCC and PBP for Weatherized Furnaces (Low Growth)

\begin{tabular}{|c|c|c|c|c|c|c|c|}
\hline \multirow[b]{2}{*}{$\begin{array}{l}\text { Design Option: } \\
\text { AFUE/Electricity }\end{array}$} & \multicolumn{5}{|c|}{ LCC } & \multicolumn{2}{|c|}{ Payback } \\
\hline & Average & $\begin{array}{l}\text { Average } \\
\text { Savings }\end{array}$ & $\begin{array}{l}\text { Net } \\
\text { Cost }\end{array}$ & $\begin{array}{c}\text { No } \\
\text { Impact* }\end{array}$ & $\begin{array}{c}\text { Net } \\
\text { Benefit }\end{array}$ & Median & Average* \\
\hline 78\% Baseline & $\$ 8,468$ & & & & & & \\
\hline 80\% Incr. HX Area & $\$ 8,381$ & $\$ 2$ & $0 \%$ & $98 \%$ & $2 \%$ & 1.1 & 1.5 \\
\hline 80\% Improved Insulation & $\$ 8,378$ & $\$ 3$ & $27 \%$ & $46 \%$ & $27 \%$ & 9.1 & 8.2 \\
\hline $80 \%$ PSC + & $\$ 8,366$ & $\$ 10$ & $7 \%$ & $46 \%$ & $47 \%$ & 3.5 & 4.1 \\
\hline $80 \%$ ECM & $\$ 8,461$ & $-\$ 41$ & $44 \%$ & $46 \%$ & $10 \%$ & 20.1 & 27.9 \\
\hline 80\% Improved Heat Xfer & $\$ 8,391$ & $-\$ 4$ & $52 \%$ & $46 \%$ & $2 \%$ & 2.9 & 3.8 \\
\hline 81\% Incr. HX Area & $\$ 8,343$ & $\$ 22$ & $2 \%$ & $46 \%$ & $52 \%$ & 2.1 & 2.7 \\
\hline 81\% Improved Insulation & $\$ 8,340$ & $\$ 25$ & $20 \%$ & $20 \%$ & $60 \%$ & 5.3 & 6.5 \\
\hline $81 \%$ PSC+ & $\$ 8,328$ & $\$ 35$ & $5 \%$ & $20 \%$ & $75 \%$ & 2.8 & 3.4 \\
\hline 81\% ECM & $\$ 8,423$ & $-\$ 41$ & $60 \%$ & $20 \%$ & $20 \%$ & 16.7 & 22.0 \\
\hline 81\% Improved Heat Xfer & $\$ 8,349$ & $\$ 18$ & $32 \%$ & $20 \%$ & $48 \%$ & 3.9 & 5.2 \\
\hline 82\% Incr. HX Area & $\$ 8,306$ & $\$ 52$ & $3 \%$ & $20 \%$ & $77 \%$ & 2.2 & 3.0 \\
\hline 82\% Improved Insulation & $\$ 8,303$ & $\$ 55$ & $19 \%$ & $0 \%$ & $81 \%$ & 4.4 & 5.7 \\
\hline $82 \%$ PSC+ & $\$ 8,291$ & $\$ 67$ & $4 \%$ & $0 \%$ & $96 \%$ & 2.7 & 3.3 \\
\hline $82 \%$ ECM & $\$ 8,385$ & $-\$ 28$ & $67 \%$ & $0 \%$ & $33 \%$ & 14.7 & 19.0 \\
\hline 82\% Improved Heat Xfer & $\$ 8,307$ & $\$ 51$ & $24 \%$ & $0 \%$ & $76 \%$ & 2.6 & 3.5 \\
\hline 83\% Incr. HX Area & $\$ 8,274$ & $\$ 84$ & $7 \%$ & $0 \%$ & $93 \%$ & 3.0 & 4.0 \\
\hline 83\% Improved Insulation & $\$ 8,271$ & $\$ 87$ & $12 \%$ & $0 \%$ & $88 \%$ & 4.0 & 5.6 \\
\hline $83 \%$ PSC+ & $\$ 8,259$ & $\$ 99$ & $4 \%$ & $0 \%$ & $96 \%$ & 3.0 & 3.7 \\
\hline $83 \%$ ECM & $\$ 8,353$ & $\$ 4$ & $60 \%$ & $0 \%$ & $40 \%$ & 12.7 & 15.5 \\
\hline 83\% Improved Heat Xfer & $\$ 8,271$ & $\$ 87$ & $4 \%$ & $0 \%$ & $96 \%$ & 2.5 & 3.4 \\
\hline
\end{tabular}

* "No impact" means that the base case furnace assigned to the household has greater efficiency than the level indicated, so the household is not affected. 


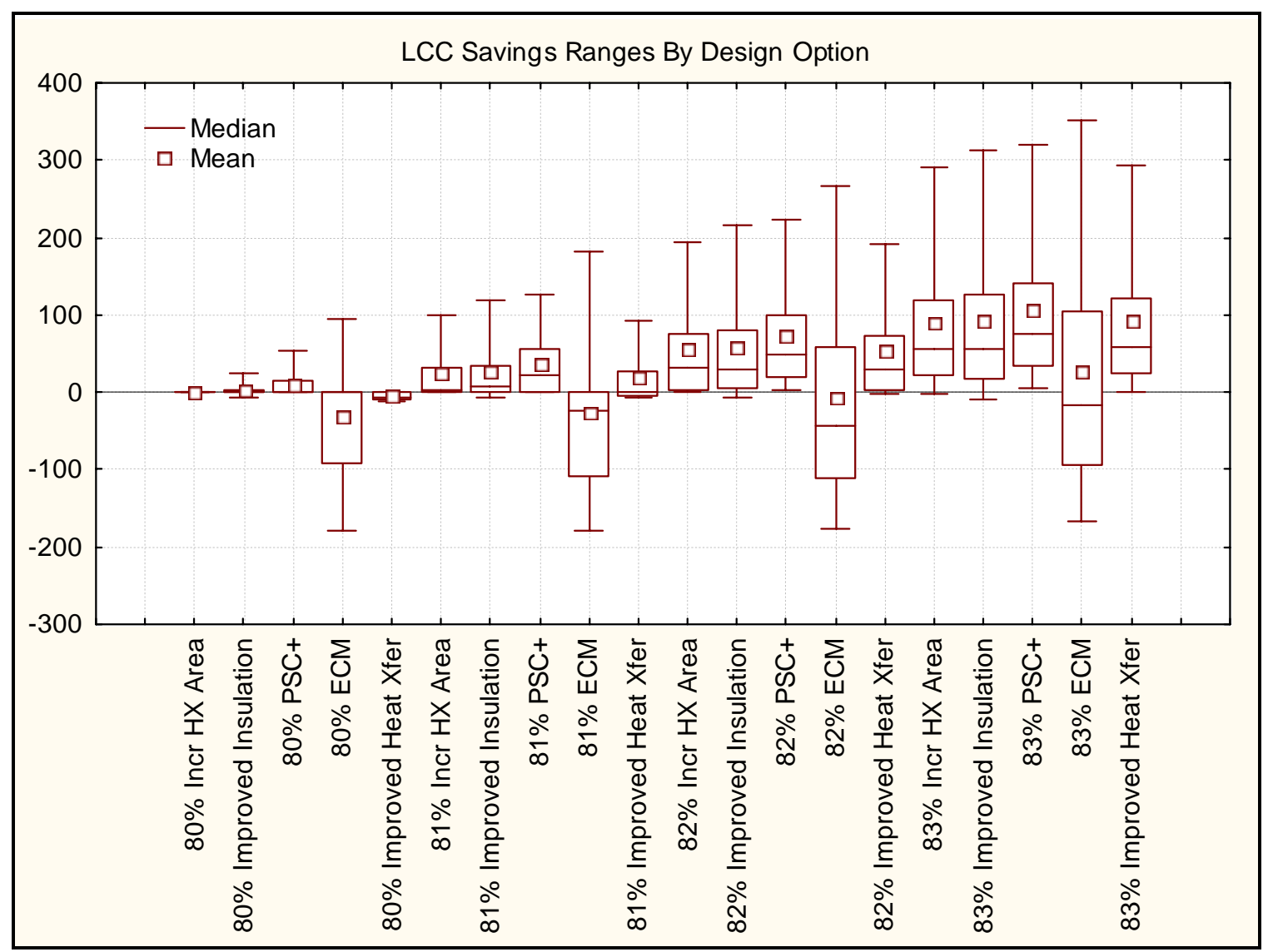

Figure C.3.2 National LCC Savings Results for Weatherized Furnaces (Low Growth) 
Table C.3.3 LCC and PBP Results for Manufactured Home Furnaces (Low Growth)

\begin{tabular}{|l|c|c|c|c|c|c|c|}
\hline & \multicolumn{3}{|c|}{ LCC } & \multicolumn{3}{c|}{ Payback } \\
\hline $\begin{array}{l}\text { Design Option: } \\
\text { AFUE/Electricity }\end{array}$ & $\begin{array}{c}\text { Average } \\
\text { LCC }\end{array}$ & $\begin{array}{c}\text { Average } \\
\text { Savings }\end{array}$ & Net Cost & $\begin{array}{c}\text { No } \\
\text { Impact* }\end{array}$ & $\begin{array}{c}\text { Net } \\
\text { Benefit }\end{array}$ & Median & Average* \\
\hline $75 \%$ Baseline & $\$ 7,797$ & & & & & \\
\hline $80 \%$ & $\$ 7,379$ & $\$ 64$ & $1 \%$ & $85 \%$ & $14 \%$ & 2.4 & 5.2 \\
\hline $80 \%$ ECM & $\$ 7,480$ & $-\$ 32$ & $69 \%$ & $5 \%$ & $26 \%$ & 20.8 & 36.7 \\
\hline $80 \%$ 2-stage modulation & $\$ 7,580$ & $-\$ 165$ & $80 \%$ & $5 \%$ & $15 \%$ & 25.5 & 62.6 \\
\hline $81 \%$ & $\$ 7,328$ & $\$ 112$ & $10 \%$ & $5 \%$ & $85 \%$ & 4.3 & 6.4 \\
\hline $81 \%$ ECM & $\$ 7,429$ & $\$ 16$ & $60 \%$ & $5 \%$ & $35 \%$ & 16.2 & 22.0 \\
\hline $81 \%$ 2-stage modulation & $\$ 7,533$ & $-\$ 120$ & $75 \%$ & $5 \%$ & $20 \%$ & 25.3 & 62.1 \\
\hline $82 \%$ & $\$ 7,286$ & $\$ 152$ & $14 \%$ & $5 \%$ & $81 \%$ & 5.1 & 7.7 \\
\hline $82 \%$ ECM & $\$ 7,387$ & $\$ 57$ & $51 \%$ & $5 \%$ & $44 \%$ & 13.8 & 17.9 \\
\hline $82 \%$ 2-stage modulation & $\$ 7,495$ & $-\$ 83$ & $70 \%$ & $5 \%$ & $25 \%$ & 23.0 & 57.5 \\
\hline $90 \%$ & $\$ 7,257$ & $\$ 179$ & $46 \%$ & $5 \%$ & $49 \%$ & 12.5 & 23.5 \\
\hline
\end{tabular}
"No impact" means that the base case furnace
indicated, so the household is not affected. 


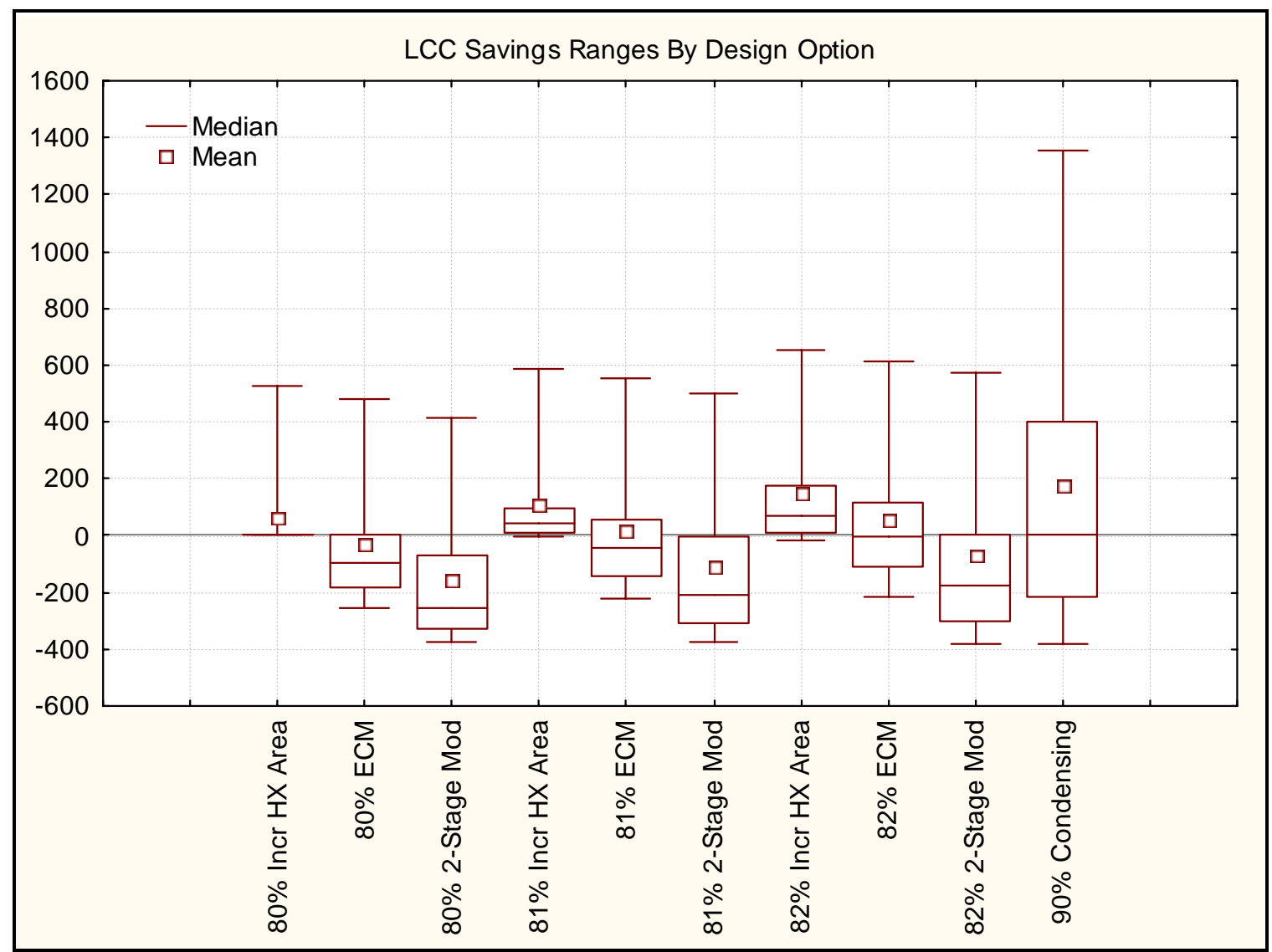

Figure C.3.3 National LCC Savings Results for Manufactured Home Furnaces (Low Growth) 
Table C.3.4 LCC and PBP Results for Oil Furnaces (Low Growth)

\begin{tabular}{|c|c|c|c|c|c|c|c|}
\hline \multirow[b]{2}{*}{$\begin{array}{l}\text { Design Option: } \\
\text { AFUE/Electricity }\end{array}$} & \multicolumn{5}{|c|}{ LCC } & \multicolumn{2}{|c|}{ Payback } \\
\hline & Average & $\begin{array}{l}\text { Average } \\
\text { Savings }\end{array}$ & $\begin{array}{l}\text { Net } \\
\text { Cost }\end{array}$ & $\begin{array}{c}\text { No } \\
\text { Impact }\end{array}$ & $\begin{array}{c}\text { Net } \\
\text { Benefit }\end{array}$ & Median & Average \\
\hline 78\% Baseline & $\$ 15,669$ & & & & & & \\
\hline 80\% Incr. HX Area & $\$ 15,388$ & $\$ 11$ & $0 \%$ & $96 \%$ & $4 \%$ & 0.2 & 0.2 \\
\hline 81\% Incr. HX Area & $\$ 15,256$ & $\$ 91$ & $2 \%$ & $39 \%$ & $59 \%$ & 0.4 & 0.5 \\
\hline 81\% Atom Burner 2-stage Mod. & $\$ 15,332$ & $-\$ 2$ & $44 \%$ & $30 \%$ & $26 \%$ & 12.3 & 22.0 \\
\hline 81\% Interrupted Ignition & $\$ 15,280$ & $\$ 74$ & $13 \%$ & $30 \%$ & $57 \%$ & 2.9 & 5.0 \\
\hline 81\% ECM & $\$ 15,443$ & $-\$ 40$ & $51 \%$ & $30 \%$ & $19 \%$ & 15.0 & 23.7 \\
\hline 82\% Incr. HX Area & $\$ 15,125$ & $\$ 182$ & $2 \%$ & $30 \%$ & $68 \%$ & 0.3 & 0.4 \\
\hline 82\% Atom Burner 2-stage Mod. & $\$ 15,207$ & $\$ 76$ & $37 \%$ & $22 \%$ & $40 \%$ & 8.9 & 14.1 \\
\hline 82\% Interrupted Ignition & $\$ 15,149$ & $\$ 164$ & $10 \%$ & $22 \%$ & $67 \%$ & 1.7 & 3.6 \\
\hline $82 \%$ ECM & $\$ 15,311$ & $\$ 38$ & $41 \%$ & $22 \%$ & $37 \%$ & 9.5 & 17.6 \\
\hline 83\% Incr. HX Area & $\$ 14,998$ & $\$ 280$ & $3 \%$ & $22 \%$ & $75 \%$ & 0.3 & 0.4 \\
\hline 83\% Atom Burner 2-stage Mod. & $\$ 15,085$ & $\$ 159$ & $33 \%$ & $15 \%$ & $52 \%$ & 7.1 & 11.9 \\
\hline 83\% Interrupted Ignition & $\$ 15,022$ & $\$ 260$ & $10 \%$ & $15 \%$ & $75 \%$ & 1.4 & 3.0 \\
\hline 83\% ECM & $\$ 15,184$ & $\$ 122$ & $34 \%$ & $15 \%$ & $51 \%$ & 7.3 & 15.4 \\
\hline 84\% Incr. HX Area & $\$ 15,479$ & $-\$ 129$ & $59 \%$ & $15 \%$ & $26 \%$ & 14.1 & 21.5 \\
\hline 84\% Atom Burner 2-stage Mod. & $\$ 15,571$ & $-\$ 265$ & $72 \%$ & $7 \%$ & $20 \%$ & 16.8 & 26.0 \\
\hline 84\% AFUE Interrupted Ignition & $\$ 15,502$ & $-\$ 151$ & $68 \%$ & $7 \%$ & $25 \%$ & 14.9 & 21.9 \\
\hline $84 \%$ ECM & $\$ 15,664$ & $-\$ 301$ & $76 \%$ & $7 \%$ & $17 \%$ & 18.3 & 34.3 \\
\hline 85\% Incr. HX Area & $\$ 15,363$ & $-\$ 22$ & $51 \%$ & $7 \%$ & $42 \%$ & 10.3 & 14.3 \\
\hline 85\% Atom Burner 2-stage Mod. & $\$ 15,461$ & $-\$ 173$ & $71 \%$ & $0 \%$ & $29 \%$ & 14.2 & 20.8 \\
\hline 85\% Interrupted Ignition & $\$ 15,386$ & $-\$ 45$ & $60 \%$ & $0 \%$ & $40 \%$ & 11.1 & 15.4 \\
\hline $85 \%$ ECM & $\$ 15,548$ & $-\$ 207$ & $74 \%$ & $0 \%$ & $26 \%$ & 15.1 & 28.4 \\
\hline
\end{tabular}

* "No impact" means that the base case furnace assigned to the household has greater efficiency than the level indicated, so the household is not affected. 


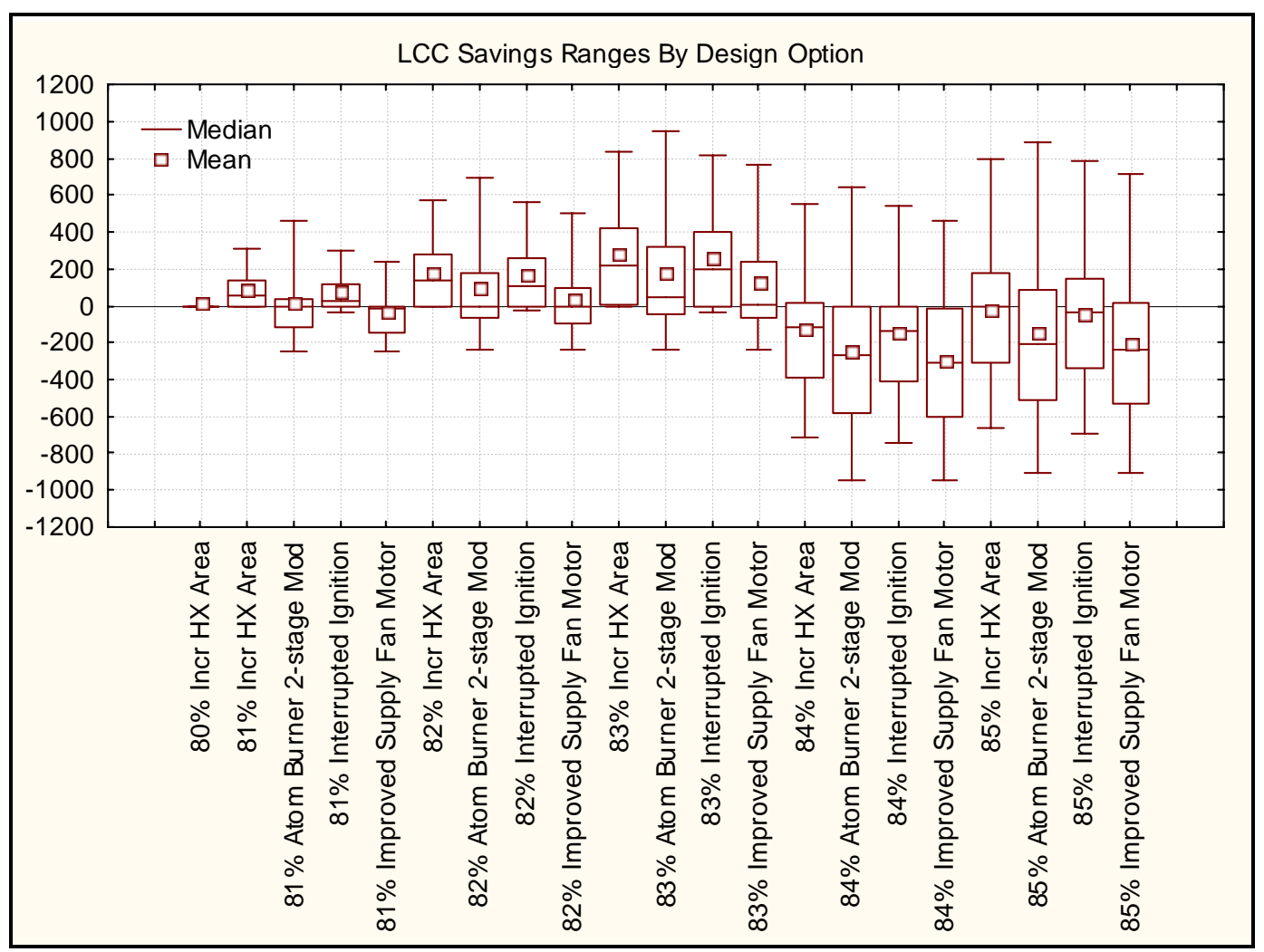

Figure C.3.4 National LCC Savings Results for Oil Furnaces (Low Growth) 
Table C.3.5 LCC and PBP Results for Oil Boilers (Low Growth)

\begin{tabular}{|c|c|c|c|c|c|c|c|}
\hline \multirow[b]{2}{*}{$\begin{array}{l}\text { Design Option: } \\
\text { AFUE/Electricity }\end{array}$} & \multicolumn{5}{|c|}{ LCC } & \multicolumn{2}{|c|}{ Payback } \\
\hline & Average & $\begin{array}{l}\text { Average } \\
\text { Savings }\end{array}$ & Net Cost & $\begin{array}{c}\text { No } \\
\text { Impact* }\end{array}$ & $\begin{array}{c}\text { Net } \\
\text { Benefit }\end{array}$ & Median & Average* \\
\hline $80 \%$ & $\$ 14,454$ & & & & & & \\
\hline $81 \%$ & $\$ 14,341$ & $\$ 6$ & $0 \%$ & $95 \%$ & $5 \%$ & 0.7 & 0.8 \\
\hline 81\% Atomized Burner & $\$ 14,729$ & $-\$ 35$ & $11 \%$ & $89 \%$ & $0 \%$ & 73.0 & 107.1 \\
\hline 81\% Inter Ign & $\$ 14,346$ & $\$ 5$ & $4 \%$ & $89 \%$ & $7 \%$ & 6.0 & 9.6 \\
\hline 81\% Imp Circ Pump & $\$ 14,566$ & $-\$ 18$ & $10 \%$ & $89 \%$ & $1 \%$ & 40.4 & 67.9 \\
\hline $82 \%$ & $\$ 14,231$ & $\$ 18$ & $0 \%$ & $89 \%$ & $11 \%$ & 0.7 & 0.8 \\
\hline 82\% Atomized Burner & $\$ 14,620$ & $-\$ 45$ & $16 \%$ & $84 \%$ & $0 \%$ & 36.8 & 67.8 \\
\hline 82\% Inter Ign & $\$ 14,236$ & $\$ 17$ & $4 \%$ & $84 \%$ & $12 \%$ & 3.5 & 6.9 \\
\hline 82\% Imp Circ Pump & $\$ 14,456$ & $-\$ 18$ & $13 \%$ & $84 \%$ & $3 \%$ & 21.9 & 46.6 \\
\hline $83 \%$ & $\$ 14,124$ & $\$ 35$ & $0 \%$ & $84 \%$ & $16 \%$ & 0.7 & 0.8 \\
\hline 83\% Atomized Burner & $\$ 14,513$ & $-\$ 118$ & $38 \%$ & $61 \%$ & $2 \%$ & 24.1 & 46.3 \\
\hline 83\% Inter Ign & $\$ 14,129$ & $\$ 33$ & $17 \%$ & $61 \%$ & $22 \%$ & 8.0 & 10.4 \\
\hline 83\% Imp Circ Pump & $\$ 14,349$ & $-\$ 54$ & $33 \%$ & $61 \%$ & $6 \%$ & 54.6 & 71.7 \\
\hline $84 \%$ & $\$ 14,019$ & $\$ 76$ & $0 \%$ & $61 \%$ & $39 \%$ & 0.7 & 0.9 \\
\hline 84\% Atomized Burner & $\$ 14,409$ & $-\$ 169$ & $58 \%$ & $37 \%$ & $4 \%$ & 28.2 & 60.1 \\
\hline 84\% Inter Ign & $\$ 14,025$ & $\$ 72$ & $18 \%$ & $37 \%$ & $45 \%$ & 3.9 & 7.7 \\
\hline 84\% Imp Circ Pump & $\$ 14,245$ & $-\$ 66$ & $52 \%$ & $37 \%$ & $11 \%$ & 24.9 & 52.3 \\
\hline $86 \%$ & $\$ 14,536$ & $-\$ 243$ & $53 \%$ & $37 \%$ & $10 \%$ & 23.7 & 32.8 \\
\hline 86\% Atomized Burner & $\$ 14,927$ & $-\$ 606$ & $91 \%$ & $7 \%$ & $2 \%$ & 54.4 & 99.7 \\
\hline 86\% Inter Ign & $\$ 14,542$ & $-\$ 248$ & $75 \%$ & $7 \%$ & $18 \%$ & 18.0 & 25.8 \\
\hline 86\% Imp Circ Pump & $\$ 14,762$ & $-\$ 453$ & $88 \%$ & $7 \%$ & $5 \%$ & 42.6 & 61.8 \\
\hline $90 \%$ & $\$ 14,874$ & $-\$ 556$ & $83 \%$ & $7 \%$ & $10 \%$ & 20.2 & 24.6 \\
\hline $95 \%$ & $\$ 15,195$ & $-\$ 877$ & $89 \%$ & $0 \%$ & $11 \%$ & 19.7 & 23.8 \\
\hline
\end{tabular}

* "No impact" means that the base case furnace assigned to the household has greater efficiency than the level indicated, so the household is not affected. 


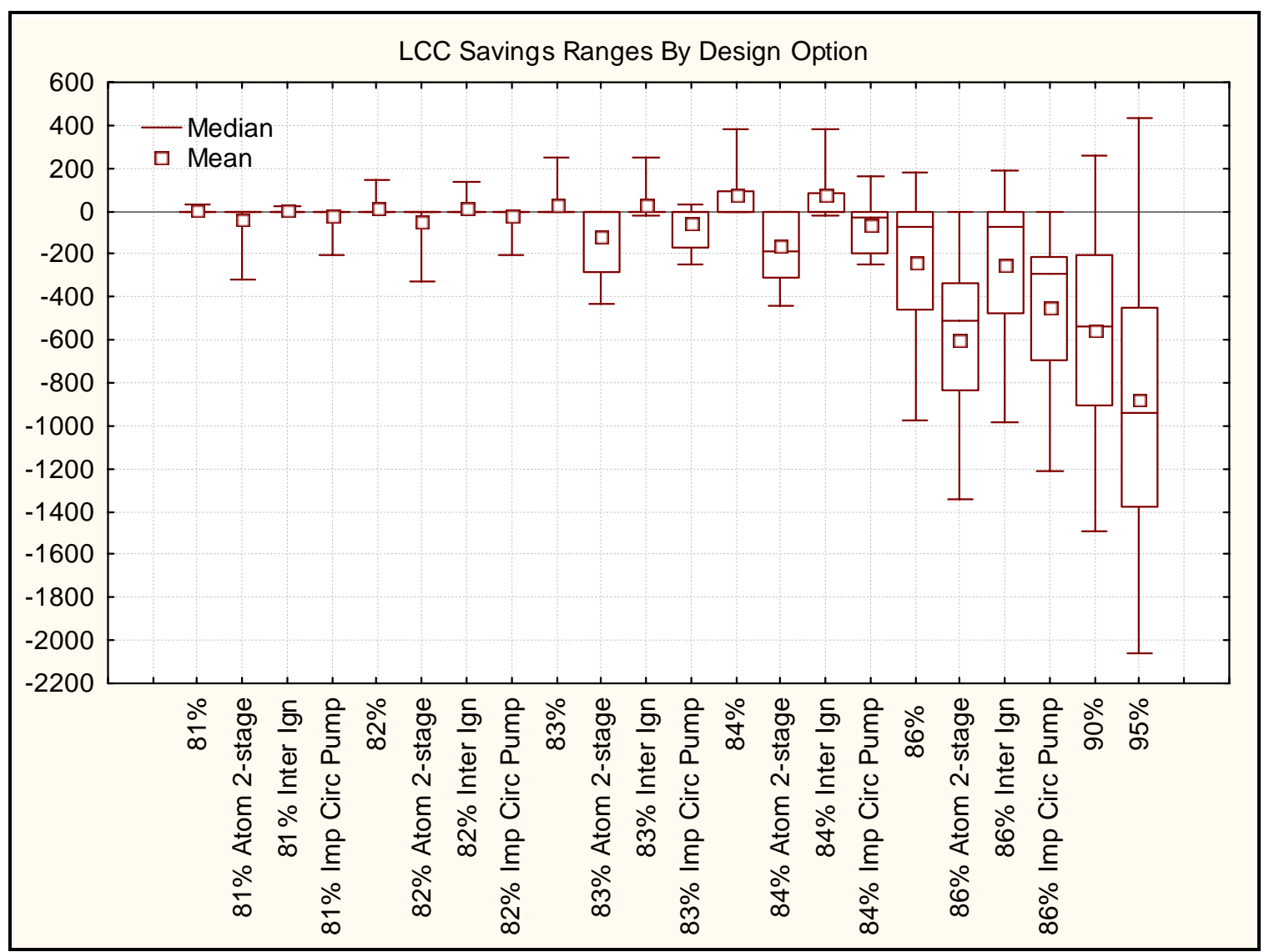

Figure C.3.5 National LCC Savings Result for Oil Boilers (Low Growth) 
Table C.3.6 LCC and PBP Results for Gas Boilers (Low Growth)

\begin{tabular}{|c|c|c|c|c|c|c|c|}
\hline \multirow[b]{2}{*}{$\begin{array}{l}\text { Design Option: } \\
\text { AFUE/Electricity }\end{array}$} & \multicolumn{5}{|c|}{ LCC } & \multicolumn{2}{|c|}{ Payback } \\
\hline & $\begin{array}{c}\text { Average } \\
\text { LCC }\end{array}$ & $\begin{array}{l}\text { Average } \\
\text { Savings }\end{array}$ & Net Cost & $\begin{array}{c}\text { No } \\
\text { Impact* }\end{array}$ & $\begin{array}{c}\text { Net } \\
\text { Benefit }\end{array}$ & Median & Average* \\
\hline 80\% Baseline & $\$ 10,536$ & & & & & & \\
\hline $81 \%$ & $\$ 10,276$ & $\$ 91$ & $0 \%$ & $65 \%$ & $35 \%$ & 2.2 & 2.5 \\
\hline 81\% 2-stage modulation & $\$ 10,409$ & $-\$ 35$ & $38 \%$ & $44 \%$ & $18 \%$ & 10.1 & 14.7 \\
\hline 81\% Imp Circ Pump & $\$ 10,527$ & $-\$ 50$ & $41 \%$ & $44 \%$ & $16 \%$ & 15.5 & 57.2 \\
\hline $82 \%$ & $\$ 10,221$ & $\$ 123$ & $3 \%$ & $44 \%$ & $53 \%$ & 2.6 & 3.3 \\
\hline $82 \%$ 2-stage modulation & $\$ 10,354$ & $-\$ 35$ & $49 \%$ & $30 \%$ & $22 \%$ & 9.7 & 21.1 \\
\hline 82\% Imp Circ Pump & $\$ 10,472$ & $-\$ 54$ & $51 \%$ & $30 \%$ & $19 \%$ & 19.6 & 44.0 \\
\hline $83 \%$ & $\$ 10,163$ & $\$ 163$ & $5 \%$ & $30 \%$ & $66 \%$ & 2.6 & 3.4 \\
\hline 83\% 2-stage modulation & $\$ 10,298$ & $-\$ 29$ & $59 \%$ & $15 \%$ & $26 \%$ & 10.2 & 24.0 \\
\hline 83\% Imp Circ Pump & $\$ 10,414$ & $-\$ 50$ & $62 \%$ & $15 \%$ & $24 \%$ & 18.3 & 40.8 \\
\hline $84 \%$ & $\$ 10,107$ & $\$ 211$ & $6 \%$ & $15 \%$ & $79 \%$ & 2.6 & 3.5 \\
\hline $84 \%$ 2-stage modulation & $\$ 10,243$ & $\$-2$ & $62 \%$ & $6 \%$ & $32 \%$ & 10.7 & 22.9 \\
\hline 84\% Imp Circ Pump & $\$ 10,358$ & $-\$ 26$ & $64 \%$ & $6 \%$ & $30 \%$ & 15.5 & 32.5 \\
\hline $88 \%$ & $\$ 10,653$ & $-\$ 301$ & $67 \%$ & $6 \%$ & $27 \%$ & 18.0 & 30.5 \\
\hline $91 \%$ & $\$ 10,739$ & $-\$ 384$ & $75 \%$ & $3 \%$ & $22 \%$ & 20.1 & 46.3 \\
\hline $99 \%$ & $\$ 11,226$ & $-\$ 870$ & $86 \%$ & $0 \%$ & $14 \%$ & 22.4 & 48.6 \\
\hline
\end{tabular}

"No impact" means that the base case furnace assigned to the household has greater efficiency than the level indicated, so the household is not affected. 


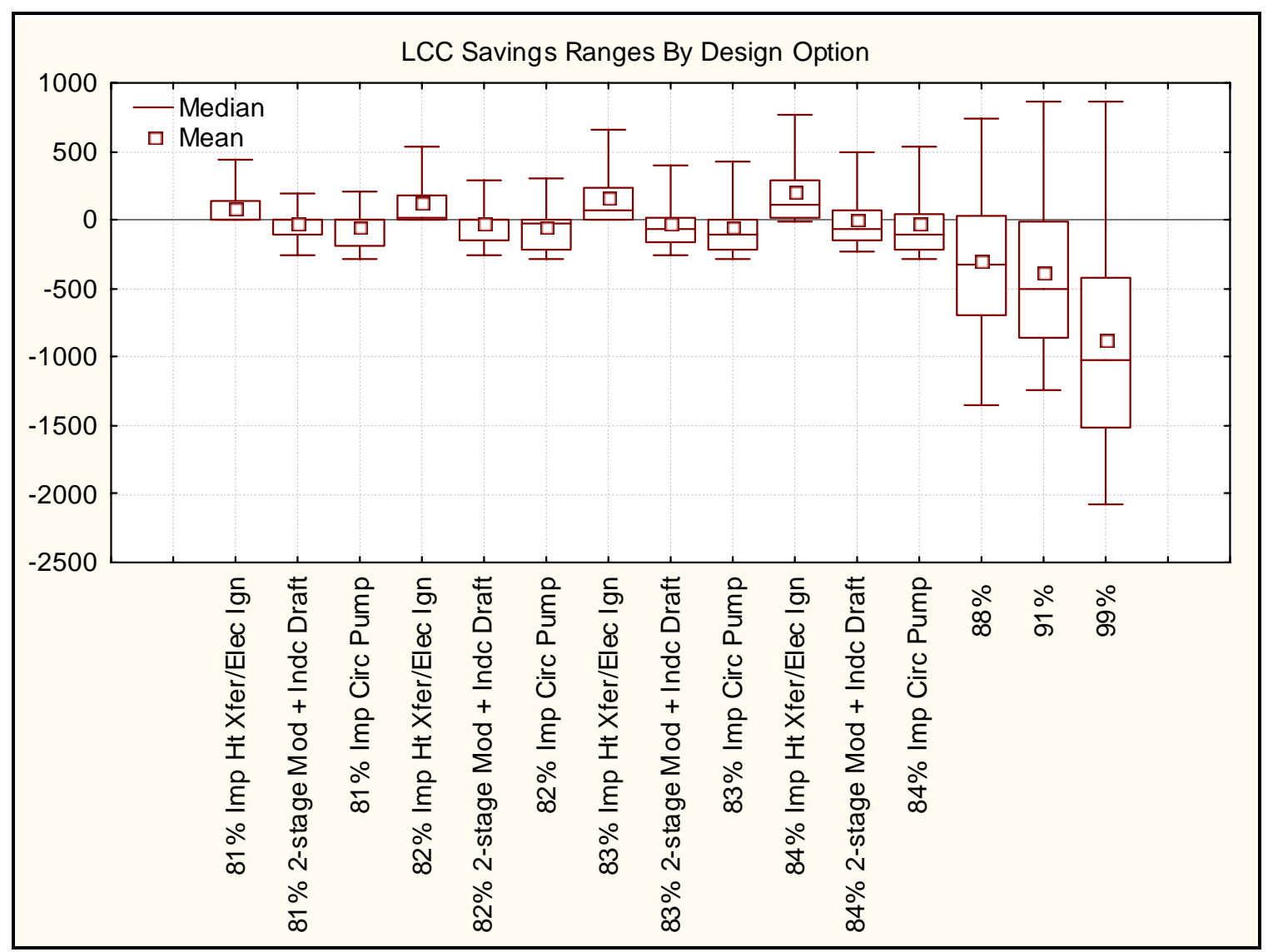

Figure C.3.6 National LCC Savings Results for Gas Boilers (Low Growth) 


\section{REFERENCES}

1. U.S. Department of Energy - Energy Information Administration, Annual Energy Outlook 2003: With Projections Through 2025, January, 2003. Washington, DC. Report No. DOE/EIA-0383(2003). <http://www.eia.doe.gov/oiaf/aeo> 



\section{APPENDIX D: LCC AND PAYBACK PERIOD RESULTS USING ALTERNATIVE INSTALLATION COST SCENARIOS}

\section{TABLE OF CONTENTS}

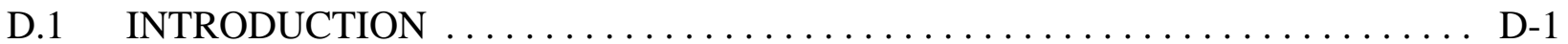

D.2 LCC AND PBP RESULTS FOR NON-WEATHERIZED GAS FURNACES

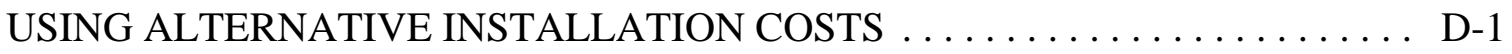

D.3 LCC AND PBP RESULTS FOR GAS BOILERS USING ALTERNATIVE

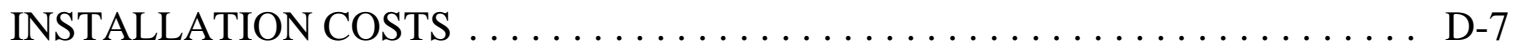

\section{LIST OF TABLES}

Table D.2.1 LCC and PBP Results for Non-Weatherized Gas Furnaces Using

GRI Installation Costs .......................... D-1

Table D.2.2 LCC and PBP Results for Non-Weatherized Gas Furnaces Using

NRCanada Installation Costs ....................... D-4

Table D.3.1 LCC and PBP Results for Hot-Water Gas Boilers Using

GRI Installation Costs $\ldots \ldots \ldots \ldots \ldots \ldots \ldots \ldots \ldots \ldots \ldots \ldots \ldots \ldots \ldots \ldots \ldots \ldots$

\section{LIST OF FIGURES}

Figure D.1 National LCC Savings for Non-Weatherized Gas Furnaces,

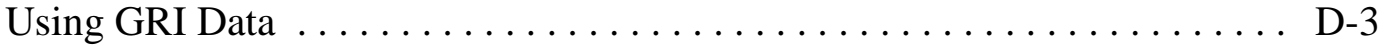

Figure D.2 National LCC Savings for Non-Weatherized Gas Furnaces,

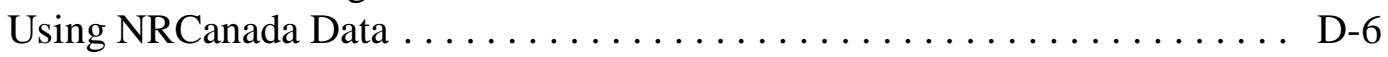

Figure D.1 National LCC Savings for Gas Boilers, Using GRI Data $\ldots \ldots \ldots \ldots \ldots$ D-8 


\section{APPENDIX D.1: LCC AND PAYBACK PERIOD RESULTS USING ALTERNATIVE INSTALLATION COST SCENARIOS}

\section{D.1 INTRODUCTION}

This appendix presents LCC and PBP results using alternative installation costs for nonweatherized gas furnaces and gas boilers. These results are presented as high and low sensitivity cases. For non-weatherized gas furnaces, DOE used two alternative sources: a 1994 Gas Research Institute (GRI) report, and data from Natural Resources Canada (NRCanada) (see References in main body of this report). For gas boilers, DOE used the GRI report as an alternative source.

\section{D.2 LCC AND PBP RESULTS FOR NON-WEATHERIZED GAS FURNACES USING ALTERNATIVE INSTALLATION COSTS}

Table D.2.1 LCC and PBP Results for Non-Weatherized Gas Furnaces Using GRI Installation Costs

\begin{tabular}{|l|c|c|c|c|c|c|c|}
\hline & \multicolumn{3}{|c|}{ LCC } & \multicolumn{2}{c|}{ Payback } \\
\hline $\begin{array}{l}\text { Design Option: } \\
\text { AFUE/Electricity }\end{array}$ & Average & $\begin{array}{c}\text { Average } \\
\text { Savings }\end{array}$ & Net Cost & $\begin{array}{c}\text { No } \\
\text { Impact* }\end{array}$ & $\begin{array}{c}\text { Net } \\
\text { Benefit }\end{array}$ & Median & Average* \\
\hline & $\$$ & $\$$ & $\%$ & $\%$ & $\%$ & years & years \\
\hline $78 \%$ & $\$ 10,022$ & & & & & & \\
\hline $80 \%$ & $\$ 10,042$ & $-\$ 1$ & $1 \%$ & $99 \%$ & $1 \%$ & 21.2 & 60.3 \\
\hline $80 \%$ PSC+ & $\$ 10,031$ & $\$ 7$ & $17 \%$ & $27 \%$ & $56 \%$ & 5.4 & 5.8 \\
\hline $80 \%$ ECM & $\$ 10,121$ & $-\$ 60$ & $60 \%$ & $27 \%$ & $14 \%$ & 23.1 & 33.8 \\
\hline $80 \%$ BC/ECM+ & $\$ 10,069$ & $-\$ 22$ & $51 \%$ & $27 \%$ & $22 \%$ & 17.3 & 26.4 \\
\hline $80 \%$ 2-stage mod. & $\$ 9,952$ & $\$ 49$ & $28 \%$ & $27 \%$ & $45 \%$ & 7.6 & 12.4 \\
\hline $80 \%$ 2-mod. ECM & $\$ 10,041$ & $-\$ 13$ & $48 \%$ & $27 \%$ & $26 \%$ & 15.3 & 21.0 \\
\hline $80 \%$ 2-stage mod. BC/ECM+ & $\$ 10,027$ & $\$ 2$ & $45 \%$ & $27 \%$ & $28 \%$ & 14.3 & 20.8 \\
\hline $81 \%$ 8\% Cat. III & $\$ 10,088$ & $-\$ 42$ & $7 \%$ & $27 \%$ & $66 \%$ & 1.4 & 38.2 \\
\hline $81 \%$ no Cat. III & $\$ 9,962$ & $\$ 50$ & $2 \%$ & $27 \%$ & $72 \%$ & 1.3 & 2.6 \\
\hline $81 \%$ PSC+ & $\$ 10,077$ & $-\$ 34$ & $8 \%$ & $26 \%$ & $66 \%$ & 2.2 & 29.4 \\
\hline $81 \%$ ECM & $\$ 10,167$ & $-\$ 101$ & $49 \%$ & $26 \%$ & $25 \%$ & 15.5 & 30.9 \\
\hline $81 \%$ BC/ECM+ & $\$ 10,115$ & $-\$ 63$ & $42 \%$ & $26 \%$ & $32 \%$ & 13.0 & 26.7 \\
\hline $\begin{array}{l}81 \% \text { 2-stage Mod, 8\% Cat. } \\
\text { III }\end{array}$ & $\$ 10,005$ & $\$ 4$ & $21 \%$ & $26 \%$ & $53 \%$ & 5.6 & 29.1 \\
\hline
\end{tabular}




\begin{tabular}{|c|c|c|c|c|c|c|c|}
\hline 81\% 2-stage Mod, no Cat. III & $\$ 9,879$ & $\$ 97$ & $16 \%$ & $26 \%$ & $57 \%$ & 5.1 & 9.0 \\
\hline 81\% 2-stage Mod ECM & $\$ 10,093$ & $-\$ 58$ & $41 \%$ & $26 \%$ & $32 \%$ & 12.9 & 24.5 \\
\hline 81\% 2-stage Mod BC/ECM+ & $\$ 10,078$ & $-\$ 43$ & $39 \%$ & $26 \%$ & $34 \%$ & 12.2 & 23.5 \\
\hline $82 \%$ & $\$ 10,808$ & $-\$ 579$ & $70 \%$ & $26 \%$ & $4 \%$ & 8.4 & 204.4 \\
\hline $82 \%$ PSC + & $\$ 10,798$ & $-\$ 571$ & $70 \%$ & $26 \%$ & $4 \%$ & 12.0 & 192.8 \\
\hline $82 \%$ ECM & $\$ 10,887$ & $-\$ 638$ & $71 \%$ & $26 \%$ & $3 \%$ & 66.6 & 189.6 \\
\hline $82 \% \mathrm{BC} / \mathrm{ECM}+$ & $\$ 10,836$ & $-\$ 600$ & $67 \%$ & $26 \%$ & $6 \%$ & 49.1 & 141.3 \\
\hline $82 \%$ 2-stage Mod & $\$ 10,729$ & $-\$ 534$ & $64 \%$ & $26 \%$ & $10 \%$ & 21.9 & 129.2 \\
\hline 82\% 2-stage Mod ECM & $\$ 10,816$ & $-\$ 597$ & $67 \%$ & $26 \%$ & $7 \%$ & 47.5 & 143.0 \\
\hline 82\% 2-stage Mod BC/ECM+ & $\$ 10,801$ & $-\$ 581$ & $65 \%$ & $26 \%$ & $8 \%$ & 40.6 & 119.7 \\
\hline $83 \%$ & $\$ 11,685$ & $-\$ 1,235$ & $74 \%$ & $26 \%$ & $0 \%$ & 177.5 & 345.8 \\
\hline 90\% Baseline Cond. & $\$ 10,181$ & $-\$ 168$ & $49 \%$ & $26 \%$ & $25 \%$ & 15.8 & 46.1 \\
\hline $90 \%$ PSC + & $\$ 10,171$ & $-\$ 159$ & $51 \%$ & $15 \%$ & $34 \%$ & 11.8 & 41.0 \\
\hline $90 \%$ ECM & $\$ 10,272$ & $-\$ 240$ & $60 \%$ & $15 \%$ & $24 \%$ & 20.3 & 48.6 \\
\hline $90 \%$ BC/ECM+ & $\$ 10,221$ & $-\$ 194$ & $58 \%$ & $15 \%$ & $27 \%$ & 18.1 & 43.5 \\
\hline 91\% 2-stage Mod ECM & $\$ 10,161$ & $-\$ 153$ & $54 \%$ & $15 \%$ & $31 \%$ & 15.1 & 41.6 \\
\hline 91\% 2-stage BC/ECM+ & $\$ 10,140$ & $-\$ 131$ & $53 \%$ & $15 \%$ & $31 \%$ & 15.1 & 37.8 \\
\hline 91\% Step Mod ECM & $\$ 10,382$ & $-\$ 341$ & $63 \%$ & $15 \%$ & $21 \%$ & 21.2 & 54.9 \\
\hline 91\% Step Mod BC/ECM+ & $\$ 10,373$ & $-\$ 328$ & $63 \%$ & $15 \%$ & $22 \%$ & 21.0 & 49.0 \\
\hline 92\%Incr. HX Area & $\$ 10,189$ & $-\$ 180$ & $55 \%$ & $15 \%$ & $30 \%$ & 14.6 & 43.3 \\
\hline $92 \%$ PSC+ & $\$ 10,179$ & $-\$ 170$ & $58 \%$ & $2 \%$ & $40 \%$ & 11.7 & 36.8 \\
\hline 92\% ECM & $\$ 10,280$ & $-\$ 269$ & $72 \%$ & $2 \%$ & $26 \%$ & 20.6 & 45.8 \\
\hline $92 \% \mathrm{BC} / \mathrm{ECM}+$ & $\$ 10,229$ & $-\$ 219$ & $69 \%$ & $2 \%$ & $30 \%$ & 18.4 & 39.6 \\
\hline 93\% 2-stage Mod ECM & $\$ 10,175$ & $-\$ 167$ & $63 \%$ & $2 \%$ & $35 \%$ & 15.0 & 39.1 \\
\hline 93\% 2-stage Mod BC/ECM+ & $\$ 10,154$ & $-\$ 145$ & $63 \%$ & $2 \%$ & $36 \%$ & 15.0 & 36.1 \\
\hline 93\% Step Mod ECM & $\$ 10,397$ & $-\$ 385$ & $75 \%$ & $2 \%$ & $24 \%$ & 21.1 & 50.5 \\
\hline 93\% Step Mod BC/ECM+ & $\$ 10,387$ & $-\$ 375$ & $74 \%$ & $2 \%$ & $24 \%$ & 20.9 & 45.3 \\
\hline 96\% Step Mod ECM & $\$ 11,016$ & $-\$ 995$ & $87 \%$ & $2 \%$ & $11 \%$ & 31.6 & 91.8 \\
\hline 96\% Step Mod BC/ECM+ & $\$ 11,029$ & $-\$ 1,008$ & $89 \%$ & $0 \%$ & $11 \%$ & 32.5 & 87.4 \\
\hline
\end{tabular}

* "No impact" means that the base case furnace assigned to the household has greater efficiency than the level indicated, so the household is not affected. 


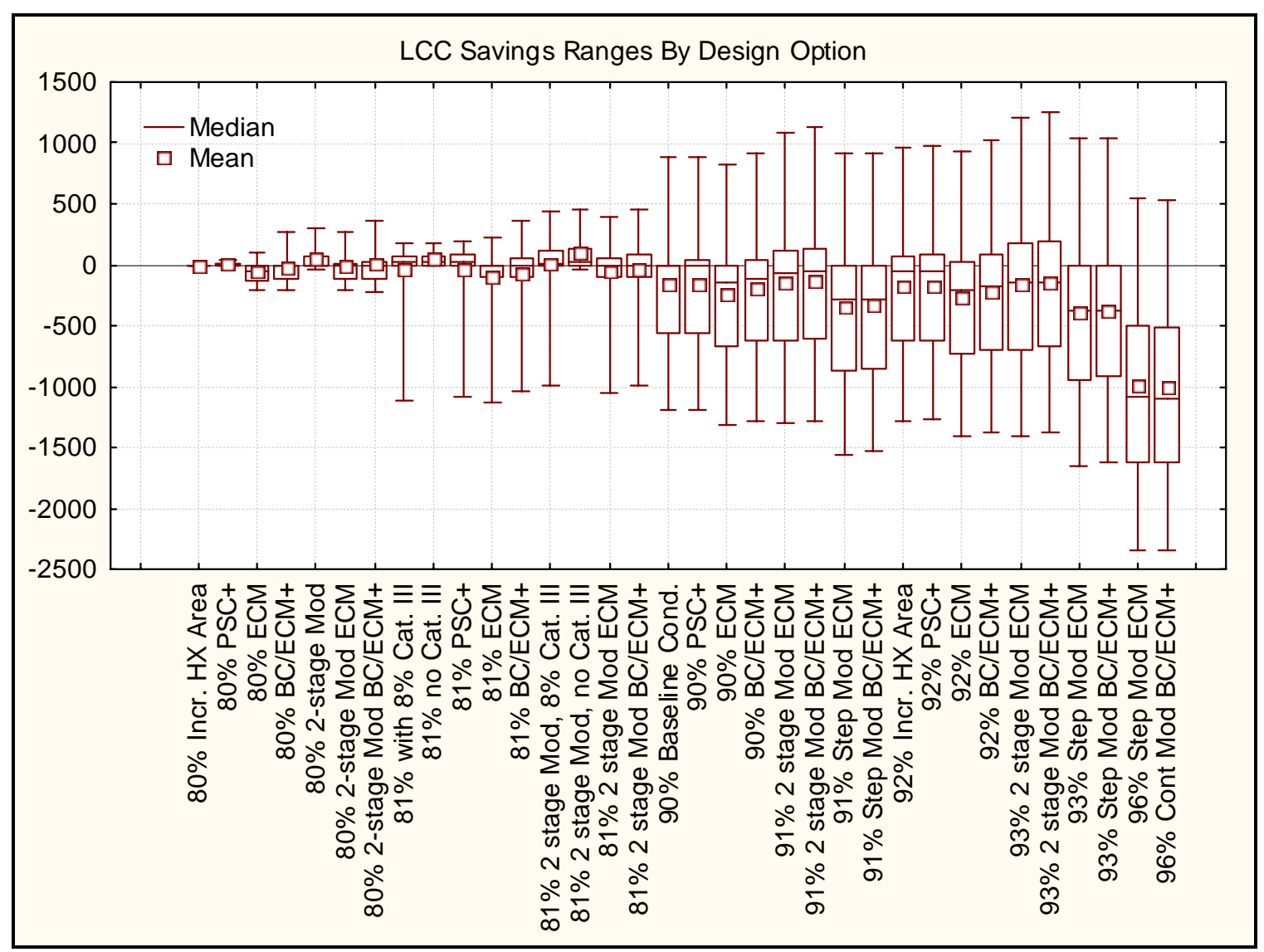

Figure D.1 National LCC Savings for Non-Weatherized Gas Furnaces, Using GRI Data 
Table D.2.2 LCC and PBP Results for Non-Weatherized Gas Furnaces Using NRCanada Installation Costs

\begin{tabular}{|c|c|c|c|c|c|c|c|}
\hline \multirow[b]{2}{*}{$\begin{array}{l}\text { Design Option: } \\
\text { AFUE/Electricity }\end{array}$} & \multicolumn{5}{|c|}{ LCC } & \multicolumn{2}{|c|}{ Payback } \\
\hline & Average & $\begin{array}{l}\text { Average } \\
\text { Savings }\end{array}$ & Net Cost & $\begin{array}{c}\text { No } \\
\text { Impact* }\end{array}$ & $\begin{array}{c}\text { Net } \\
\text { Benefit }\end{array}$ & Median & Average* \\
\hline & $\$$ & $\$$ & $\%$ & $\%$ & $\%$ & years & years \\
\hline $78 \%$ & $\$ 9,656$ & & & & & & \\
\hline $80 \%$ & $\$ 9,483$ & $\$ 1$ & $0 \%$ & $99 \%$ & $1 \%$ & 1.0 & 1.3 \\
\hline $80 \%$ PSC+ & $\$ 9,472$ & $\$ 9$ & $17 \%$ & $26 \%$ & $57 \%$ & 5.3 & 4.7 \\
\hline $80 \%$ ECM & $\$ 9,561$ & $-\$ 57$ & $60 \%$ & $26 \%$ & $14 \%$ & 22.6 & 33.0 \\
\hline $80 \%$ BC/ECM+ & $\$ 9,508$ & $-\$ 18$ & $50 \%$ & $26 \%$ & $23 \%$ & 17.0 & 25.7 \\
\hline 80\% 2-stage mod. & $\$ 9,393$ & $\$ 51$ & $27 \%$ & $26 \%$ & $46 \%$ & 7.2 & 11.4 \\
\hline 80\% 2-mod. ECM & $\$ 9,481$ & $-\$ 10$ & $47 \%$ & $26 \%$ & $26 \%$ & 14.9 & 20.1 \\
\hline $80 \%$ 2-stage mod. BC/ECM+ & $\$ 9,466$ & $\$ 6$ & $45 \%$ & $26 \%$ & $29 \%$ & 14.1 & 20.0 \\
\hline 81\% 8\% Cat. III & $\$ 9,472$ & $\$ 2$ & $7 \%$ & $26 \%$ & $67 \%$ & 1.4 & 20.1 \\
\hline 81\% no Cat. III & $\$ 9,403$ & $\$ 53$ & $1 \%$ & $26 \%$ & $72 \%$ & 1.3 & 1.8 \\
\hline $81 \%$ PSC+ & $\$ 9,462$ & $\$ 10$ & $8 \%$ & $26 \%$ & $67 \%$ & 2.1 & 16.2 \\
\hline $81 \%$ ECM & $\$ 9,551$ & $-\$ 57$ & $49 \%$ & $26 \%$ & $25 \%$ & 15.3 & 24.8 \\
\hline 81\% BC/ECM+ & $\$ 9,498$ & $-\$ 17$ & $42 \%$ & $26 \%$ & $32 \%$ & 12.8 & 21.8 \\
\hline $\begin{array}{l}\text { 81\% 2-stage Mod, 8\% Cat. } \\
\text { III }\end{array}$ & $\$ 9,389$ & $\$ 48$ & $20 \%$ & $26 \%$ & $54 \%$ & 5.4 & 18.7 \\
\hline 81\% 2-stage Mod, no Cat. III & $\$ 9,320$ & $\$ 100$ & $16 \%$ & $26 \%$ & $59 \%$ & 4.9 & 8.2 \\
\hline 81\% 2-stage Mod ECM & $\$ 9,476$ & $-\$ 13$ & $42 \%$ & $26 \%$ & $33 \%$ & 12.6 & 19.8 \\
\hline 81\% 2-stage Mod BC/ECM+ & $\$ 9,461$ & $\$ 3$ & $39 \%$ & $26 \%$ & $35 \%$ & 12.0 & 19.4 \\
\hline $82 \%$ & $\$ 9,970$ & $-\$ 375$ & $70 \%$ & $26 \%$ & $4 \%$ & 7.3 & 100.6 \\
\hline $82 \%$ PSC+ & $\$ 9,959$ & $-\$ 367$ & $69 \%$ & $26 \%$ & $5 \%$ & 9.6 & 102.7 \\
\hline $82 \%$ ECM & $\$ 10,048$ & $-\$ 433$ & $71 \%$ & $26 \%$ & $4 \%$ & 53.5 & 128.2 \\
\hline $82 \% \mathrm{BC} / \mathrm{ECM}+$ & $\$ 9,996$ & $-\$ 394$ & $67 \%$ & $26 \%$ & $7 \%$ & 39.0 & 94.8 \\
\hline 82\% 2-stage Mod & $\$ 9,890$ & $-\$ 330$ & $64 \%$ & $26 \%$ & $10 \%$ & 17.0 & 75.6 \\
\hline 82\% 2-stage Mod ECM & $\$ 9,976$ & $-\$ 391$ & $67 \%$ & $26 \%$ & $8 \%$ & 37.6 & 98.9 \\
\hline 82\% 2-stage Mod BC/ECM+ & $\$ 9,960$ & $-\$ 375$ & $65 \%$ & $26 \%$ & $9 \%$ & 33.2 & 88.5 \\
\hline $83 \%$ & $\$ 10,422$ & $-\$ 718$ & $74 \%$ & $26 \%$ & $0 \%$ & 93.0 & 193.7 \\
\hline 90\% Baseline Cond. & $\$ 9,373$ & $\$ 18$ & $45 \%$ & $26 \%$ & $29 \%$ & 10.7 & 25.2 \\
\hline $90 \%$ PSC+ & $\$ 9,363$ & $\$ 27$ & $46 \%$ & $16 \%$ & $38 \%$ & 8.9 & 23.0 \\
\hline
\end{tabular}




\begin{tabular}{|c|c|c|c|c|c|c|c|}
\hline $90 \%$ ECM & $\$ 9,463$ & $-\$ 54$ & $57 \%$ & $16 \%$ & $27 \%$ & 15.8 & 33.5 \\
\hline $90 \% \mathrm{BC} / \mathrm{ECM}+$ & $\$ 9,412$ & $-\$ 8$ & $54 \%$ & $16 \%$ & $31 \%$ & 14.3 & 31.0 \\
\hline 91\% 2-stage Mod ECM & $\$ 9,352$ & $\$ 32$ & $50 \%$ & $16 \%$ & $34 \%$ & 12.5 & 29.6 \\
\hline 91\% 2-stage BC/ECM+ & $\$ 9,331$ & $\$ 55$ & $49 \%$ & $16 \%$ & $36 \%$ & 12.4 & 27.2 \\
\hline 91\% Step Mod ECM & $\$ 9,572$ & $-\$ 154$ & $61 \%$ & $16 \%$ & $24 \%$ & 18.1 & 42.8 \\
\hline 91\% Step Mod BC/ECM+ & $\$ 9,563$ & $-\$ 142$ & $60 \%$ & $16 \%$ & $24 \%$ & 17.9 & 39.1 \\
\hline 92\%Incr. HX Area & $\$ 9,380$ & $\$ 6$ & $51 \%$ & $16 \%$ & $33 \%$ & 12.0 & 28.3 \\
\hline $92 \%$ PSC + & $\$ 9,370$ & $\$ 15$ & $55 \%$ & $2 \%$ & $44 \%$ & 10.1 & 25.2 \\
\hline $92 \%$ ECM & $\$ 9,471$ & $-\$ 84$ & $69 \%$ & $2 \%$ & $29 \%$ & 17.6 & 35.7 \\
\hline $92 \% \mathrm{BC} / \mathrm{ECM}+$ & $\$ 9,420$ & $-\$ 33$ & $65 \%$ & $2 \%$ & $33 \%$ & 15.6 & 31.1 \\
\hline 93\% 2-stage Mod ECM & $\$ 9,365$ & $\$ 19$ & $59 \%$ & $2 \%$ & $39 \%$ & 13.3 & 31.1 \\
\hline 93\% 2-stage Mod BC/ECM+ & $\$ 9,343$ & $\$ 41$ & $58 \%$ & $2 \%$ & $40 \%$ & 13.3 & 27.8 \\
\hline 93\% Step Mod ECM & $\$ 9,587$ & $-\$ 199$ & $72 \%$ & $2 \%$ & $26 \%$ & 18.9 & 41.6 \\
\hline 93\% Step Mod BC/ECM+ & $\$ 9,577$ & $-\$ 189$ & $71 \%$ & $2 \%$ & $27 \%$ & 18.7 & 38.5 \\
\hline 96\% Step Mod ECM & $\$ 10,175$ & $-\$ 777$ & $87 \%$ & $2 \%$ & $11 \%$ & 27.6 & 73.1 \\
\hline 96\% Step Mod BC/ECM+ & $\$ 10,187$ & $-\$ 790$ & $89 \%$ & $0 \%$ & $12 \%$ & 28.3 & 76.4 \\
\hline
\end{tabular}

* "No impact" means that the base case furnace assigned to the household has greater efficiency than the level indicated, so the household is not affected. 


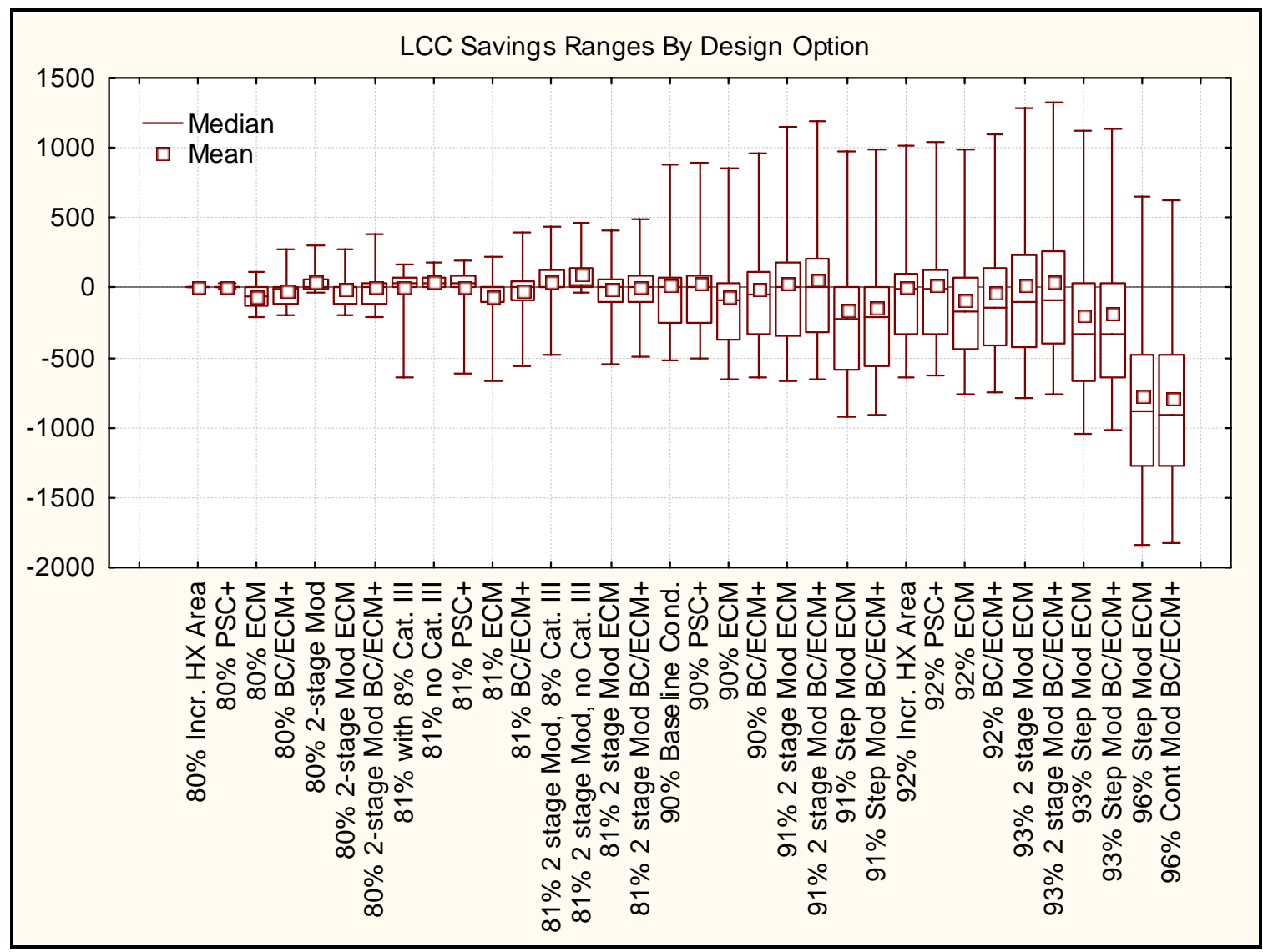

Figure D.2 National LCC Savings for Non-Weatherized Gas Furnaces, Using NRCanada Data 


\section{D.3 LCC AND PBP RESULTS FOR GAS BOILERS USING ALTERNATIVE INSTALLATION COSTS}

Table D.3.1 LCC and PBP Results for Hot-Water Gas Boilers Using GRI Installation Costs

\begin{tabular}{|c|c|c|c|c|c|c|c|}
\hline \multirow[b]{2}{*}{$\begin{array}{l}\text { Design Option: } \\
\text { AFUE/Electricity }\end{array}$} & \multicolumn{5}{|c|}{ LCC } & \multicolumn{2}{|c|}{ Payback } \\
\hline & $\begin{array}{c}\text { Average } \\
\text { LCC }\end{array}$ & $\begin{array}{l}\text { Average } \\
\text { Savings }\end{array}$ & Net Cost & $\begin{array}{c}\text { No } \\
\text { Impact }\end{array}$ & $\begin{array}{c}\text { Net } \\
\text { Benefit }\end{array}$ & Median & Average \\
\hline 80\% Baseline & $\$ 10,564$ & & & & & & \\
\hline $81 \%$ & $\$ 10,299$ & $\$ 93$ & $0 \%$ & $65 \%$ & $35 \%$ & 2.1 & 2.4 \\
\hline 81\% 2-stage modulation & $\$ 10,522$ & $-\$ 33$ & $38 \%$ & $44 \%$ & $19 \%$ & 9.7 & 14.4 \\
\hline 81\% Imp Circ Pump & $\$ 10,549$ & $-\$ 48$ & $41 \%$ & $44 \%$ & $16 \%$ & 15.1 & 55.9 \\
\hline $82 \%$ & $\$ 10,243$ & $\$ 125$ & $3 \%$ & $44 \%$ & $53 \%$ & 2.5 & 3.3 \\
\hline $82 \% 2$-stage modulation & $\$ 10,465$ & $-\$ 32$ & $48 \%$ & $30 \%$ & $23 \%$ & 9.3 & 19.9 \\
\hline 82\% Imp Circ Pump & $\$ 10,492$ & $-\$ 51$ & $51 \%$ & $30 \%$ & $19 \%$ & 19.1 & 42.9 \\
\hline $83 \%$ & $\$ 10,184$ & $\$ 166$ & $5 \%$ & $30 \%$ & $66 \%$ & 2.5 & 3.3 \\
\hline 83\% 2-stage modulation & $\$ 10,406$ & $-\$ 24$ & $58 \%$ & $15 \%$ & $27 \%$ & 9.9 & 23.1 \\
\hline 83\% Imp Circ Pump & $\$ 10,434$ & $-\$ 46$ & $61 \%$ & $15 \%$ & $24 \%$ & 17.8 & 39.6 \\
\hline $84 \%$ & $\$ 10,127$ & $\$ 215$ & $6 \%$ & $15 \%$ & $79 \%$ & 2.5 & 3.4 \\
\hline 84\% 2-stage modulation & $\$ 10,350$ & $\$ 5$ & $61 \%$ & $6 \%$ & $33 \%$ & 10.4 & 22.2 \\
\hline 84\% Imp Circ Pump & $\$ 10,377$ & $-\$ 20$ & $63 \%$ & $6 \%$ & $31 \%$ & 15.1 & 31.4 \\
\hline $88 \%$ & $\$ 11,288$ & $-\$ 870$ & $68 \%$ & $6 \%$ & $26 \%$ & 27.7 & 54.0 \\
\hline $91 \%$ & $\$ 11,902$ & $-\$ 1,466$ & $82 \%$ & $3 \%$ & $15 \%$ & 40.3 & 97.0 \\
\hline $99 \%$ & $\$ 12,383$ & $-\$ 1,946$ & $90 \%$ & $0 \%$ & $10 \%$ & 33.2 & 75.1 \\
\hline
\end{tabular}




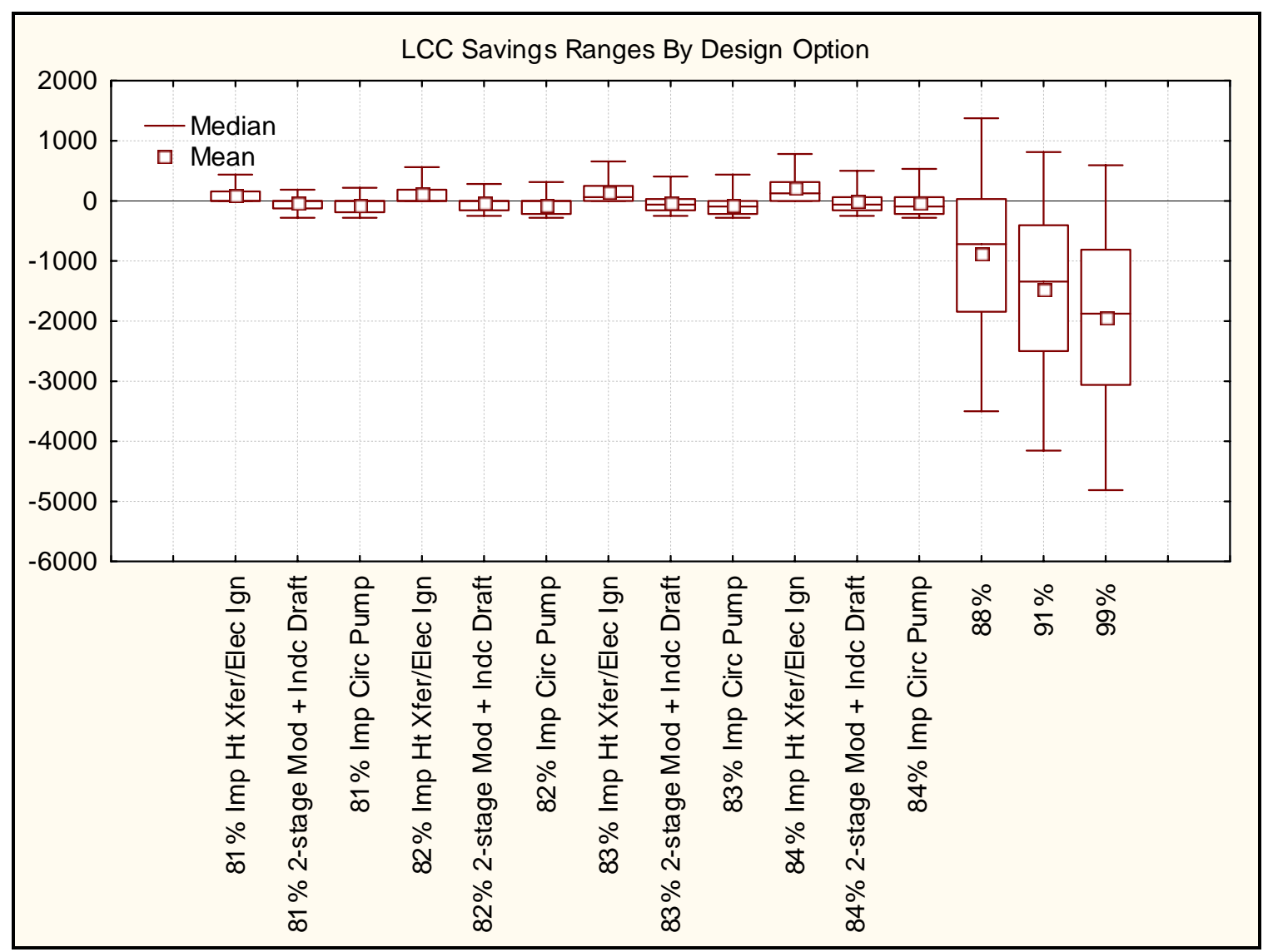

Figure D.1 National LCC Savings for Gas Boilers, Using GRI Data 